\title{
Lightning activity in Brazilian thunderstorms during TROCCINOX: implications for $\mathrm{NO}_{\mathrm{x}}$ production
}

\author{
H. Huntrieser ${ }^{1}$, U. Schumann ${ }^{1}$, H. Schlager ${ }^{1}$, H. Höller ${ }^{1}$, A. Giez ${ }^{2}$, H.-D. Betz ${ }^{3}$, D. Brunner ${ }^{4,}{ }^{*}$, C. Forster ${ }^{5,{ }^{* *}}$, O. Pinto \\ $\mathrm{Jr}^{6}$, and R. Calheiros ${ }^{7}$ \\ ${ }^{1}$ Institut für Physik der Atmosphäre, Deutsches Zentrum für Luft- und Raumfahrt (DLR), Oberpfaffenhofen, Germany \\ ${ }^{2}$ Flugabteilung, Deutsches Zentrum für Luft- und Raumfahrt (DLR), Oberpfaffenhofen, Germany \\ ${ }^{3}$ Physics Department, University of Munich, Germany \\ ${ }^{4}$ Institute for Atmospheric and Climate Science, ETH Zurich, Switzerland \\ ${ }^{5}$ Norwegian Institute for Air Research (NILU), Atmosphere and Climate Change Department, Kjeller, Norway \\ ${ }^{6}$ National Institute for Space Research, INPE, Brazil \\ ${ }^{7}$ Instituto de Pesquisas Meteorológicas - Universidade Estadual Paulista, IPMet/UNESP, Bauru, Brazil \\ *now at: Laboratory for Air Pollution and Environmental Technology, Empa, Swiss Federal Laboratories for Materials \\ Testing and Research, Dübendorf, Switzerland \\ *** now at: Institut für Physik der Atmosphäre, Deutsches Zentrum für Luft- und Raumfahrt (DLR), Oberpfaffenhofen, \\ Germany
}

Received: 12 September 2007 - Published in Atmos. Chem. Phys. Discuss.: 16 October 2007

Revised: 18 January 2008 - Accepted: 25 January 2008 - Published: 25 February 2008

\begin{abstract}
During the TROCCINOX field experiment in January and February 2005, the contribution of lightninginduced nitrogen oxides (LNOx) from tropical and subtropical thunderstorms in Southern Brazil was investigated. Airborne trace gas measurements $\left(\mathrm{NO}, \mathrm{NO}_{\mathrm{y}}, \mathrm{CO}\right.$ and $\left.\mathrm{O}_{3}\right)$ were performed up to $12.5 \mathrm{~km}$ with the German research aircraft Falcon. During anvil penetrations in selected tropical and subtropical thunderstorms of 4 and 18 February, $\mathrm{NO}_{\mathrm{x}}$ mixing ratios were on average enhanced by $0.7-1.2$ and $0.2-$ $0.8 \mathrm{nmol} \mathrm{mol}^{-1}$ totally, respectively. The relative contributions of boundary layer $\mathrm{NO}_{\mathrm{x}}(\mathrm{BL}-\mathrm{NOx})$ and LNOx to anvil$\mathrm{NO}_{\mathrm{x}}$ were derived from the $\mathrm{NO}_{\mathrm{x}}-\mathrm{CO}$ correlations. On average $\sim 80-90 \%$ of the anvil- $\mathrm{NO}_{\mathrm{x}}$ was attributed to LNOx. A Lightning Location Network (LINET) was set up to monitor the local distribution of cloud-to-ground (CG) and intracloud (IC) radiation sources (here called "strokes") and compared with lightning data from the operational Brazilian network RINDAT (Rede Integrada Nacional de Detecção de Descargas Atmosféricas). The horizontal LNOx mass flux out of the anvil was determined from the mean LNOx mix-
\end{abstract}

Correspondence to: H. Huntrieser (heidi.huntrieser@dlr.de) ing ratio, the horizontal outflow velocity and the size of the vertical cross-section of the anvil, and related to the number of strokes contributing to LNOx. The values of these parameters were derived from the airborne measurements, from lightning and radar observations, and from a trajectory analysis. The amount of LNOx produced per LINET stroke depending on measured peak current was determined. The results were scaled up with the Lightning Imaging Sensor (LIS) flash rate (44 flashes s ${ }^{-1}$ ) to obtain an estimate of the global LNOx production rate. The final results gave $\sim 1$ and $\sim 2-3 \mathrm{~kg}(\mathrm{~N})$ per LIS flash based on measurements in three tropical and one subtropical Brazilian thunderstorms, respectively, suggesting that tropical flashes may be less productive than subtropical ones. The equivalent mean annual global LNOx nitrogen mass production rate was estimated to be 1.6 and $3.1 \mathrm{Tg} \mathrm{a}^{-1}$, respectively. By use of LINET observations in Germany in July 2005, a comparison with the lightning activity in mid-latitude thunderstorms was also performed. In general, the same frequency distribution of stroke peak currents as for tropical thunderstorms over Brazil was found. The different LNOx production rates per stroke in tropical thunderstorms compared with subtropical and midlatitude thunderstorms seem to be related to the different stroke lengths (inferred from comparison with laboratory 
data and observed lengths). In comparison, the impact of other lightning parameters as stroke peak current and stroke release height was assessed to be minor. The results from TROCCINOX suggest that the different vertical wind shear may be responsible for the different stroke lengths.

\section{Introduction}

A general introduction to the LNOx topic and overviews of past and present measurements of LNOx in thunderstorms are given in accompanying papers by Huntrieser et al. (2007) (HH07) and by Schumann and Huntrieser (2007) (SH07). Observations from local field experiments have been extrapolated to the global scale to estimate the average amount of LNOx produced annually over the globe which is one crucial, yet highly uncertain, parameter in the global $\mathrm{NO}_{\mathrm{x}}$ budget. A LNOx nitrogen mass source strength between 2 and $20 \mathrm{Tg} \mathrm{a}^{-1}$ has frequently been given in the literature in the past (WMO, 1995; Bradshaw et al., 2000). More recently, lower values between 1 and $14 \mathrm{Tg} \mathrm{a}^{-1}$ have been reported based on estimates from airborne and satellite measurements (Huntrieser et al., 2002; Beirle et al., 2004, 2006; Ridley et al., 2004; Boersma et al., 2005; Ott et al., 2007). Furthermore, chemical transport models (CTMs) have been used to reduce the LNOx range by a comparison of modelled $\mathrm{NO}_{\mathrm{x}}$ concentrations, for different LNOx source strengths and vertical distributions, with local field and satellite measurements. The results obtained with model fits indicate bestestimate values for the global LNOx nitrogen mass between 2 and $8 \mathrm{Tg} \mathrm{a}^{-1}$ (SH07).

Different methods have been used to estimate the amount of LNOx based on ground-based, airborne and laboratory measurements, and theoretical calculations, as reviewed by $\mathrm{SH} 07$. Airborne $\mathrm{NO}_{\mathrm{x}}$ measurements can be combined with lightning observations to estimate the amount of LNOx produced per flash or per metre flash length. These numbers have been scaled up with the mean flash length and the annual global flash frequency. A large uncertainty in the estimate of LNOx still results from the assumed NO production rates by $\mathrm{CG}$ and IC flashes (Martin et al., 2007). Up to now, it has been suggested that most components of a discharge produce $\mathrm{NO}_{\mathrm{x}}$ with varying, not determined efficiencies (Chameides, 1986; Coppens et al., 1998; Dye et al., 2000). In addition, it has been pointed out that the different flash lengths for CG and IC flashes may play an important role in the LNOx production rate (Defer et al., 2003). Recently Rahman et al. (2007) presented first direct measurements of $\mathrm{NO}_{\mathrm{x}}$ generated by rocket-triggered lightning in the field. Based on the results from a small data set of three triggered flashes, they suggest that it is the longer-lasting and continuous current portions of flashes that are responsible for most of the NO production. In comparison, the production by short-term return strokes was found to be minor. However, these longer and continuous current portions of flashes are currently not measured by operating lightning detection networks as the National Lightning Detection Network (NLDN) and the very low frequency/low frequency (VLF/LF) lightning location network LINET used here. NLDN only detects the high-current return stroke of a discharge.

Results from the European Lightning Nitrogen Oxides Experiment (EULINOX) and Stratosphere-Troposphere Experiment: Radiation, Aerosols, and Ozone (STERAO) (DeCaria et al., 2000; Fehr et al., 2004; DeCaria et al., 2005; Ridley et al., 2005; Ott et al., 2007) indicate that IC flashes produce about as much NO per flash as $\mathrm{CG}$ flashes (IC/CG production ratio 0.5-2). In addition, laboratory results from Gallardo and Cooray (1996) and model simulations from Zhang et al. (2003) support that IC and CG flashes are similarly energetic. On the other hand, laboratory studies by Wang et al. (1998) showed that LNOx depends less on energy and more on atmospheric pressure and the peak current of the flash. They concluded that "NO production per metre discharge length as a function of peak current appears to provide a more appropriate scaling factor for estimates of total global NO production". The present study makes use of this finding by combining Wang et al. (1998) NOx measurements for laboratory flashes with our $\mathrm{NO}_{\mathrm{x}}$ and lightning peak current measurements from the field. First results were briefly presented in Huntrieser et al. (2006), indicating differences for tropical and subtropical thunderstorms in Brazil, which are discussed here in more detail. A further study is in preparation by Ott et al. $(2008)^{1}$. The authors find that the mean peak currents and the NO production amounts per flash in five different thunderstorms decrease with increasing latitude: the lowest value of NO production (360 moles/flash) was found for a EULINOX storm $\left(48^{\circ} \mathrm{N}\right)$ and the largest value of NO production (700 moles/flash) was found for a CRYSTAL-FACE storm $\left(26^{\circ} \mathrm{N}\right)$. Recently, Barthe et al. (2007) incorporated the relationship between produced LNOx per m laboratory spark and atmospheric pressure according to Wang et al. (1998) in their simulations with an explicit electrical scheme and a 3-D mesoscale model (Meso-NH).

Up to now, only a few airborne experiments have been conducted that are suitable to provide an estimate of the LNOx production rate in the tropics (see SH07). In this paper we present measurements from the "Tropical Convection, Cirrus and Nitrogen Oxides Experiment" (TROCCINOX) carried out in the wet season in January and February 2005 in the State of São Paulo and its surroundings in southern Brazil $\left(10^{\circ} \mathrm{S}\right.$ to $28^{\circ} \mathrm{S}$ and $38^{\circ} \mathrm{W}$ to $\left.55^{\circ} \mathrm{W}\right)$. Both tropical and subtropical thunderstorms were investigated, since the operation area was located along the South Atlantic convergence zone

${ }^{1}$ Ott, L. E., Pickering, K. E., DeCaria, A. J., Stenchikov, G. L., Lin, F.-F., Wang, D., Lang, S., and Tao, W.-K.: Production of lightning $\mathrm{NO}_{\mathrm{x}}$ and its vertical distribution calculated from 3-D cloud scale chemical transport simulations, in preparation, J. Geophys. Res., 2008. 
(SACZ) (HH07). The main questions of this study are: 1.) How much LNOx is produced by these tropical and subtropical thunderstorms? 2.) What are the relative contributions from strokes with different peak currents? 3.) How large is the LNOx production rate per stroke or flash? 4.) Is this LNOx production rate different for tropical and subtropical thunderstorms? 5.) What are the possible reasons for the difference? 6.) Can the findings from TROCCINOX help to explain the large LNOx productivity observed in Florida thunderstorms during CRYSTAL-FACE?

To answer these questions we analyse airborne measurements of $\mathrm{NO}, \mathrm{NO}_{\mathrm{y}}, \mathrm{CO}$, and $\mathrm{O}_{3}$ mixing ratios, the $\mathrm{J}\left(\mathrm{NO}_{2}\right)$ photolysis rate and meteorological parameters performed in the outflow of thunderstorms, trajectory analyses with the FLEXPART model and measurements from LINET, which was set up during TROCCINOX to monitor the local lightning distribution (Sect. 2). This system registers VLF/LF radiation sources (here called "strokes") from both CG and IC flashes. LINET data are compared with data from the operational Brazilian lightning detection network RINDAT (Sect. 3) and with LIS data (Sect. 4). Airborne $\mathrm{NO}_{\mathrm{x}}$ and ground-based lightning measurements are combined to give an estimate of the amount of LNOx produced per LINET stroke, and as a function of peak current according to Wang et al. (1998) (Sect. 4). From the ratio between LIS and LINET during one overpass, the amount of LNOx per LIS flash is determined. Knowing the global and annual LIS flash rate (44 \pm 5 flashes $\mathrm{s}^{-1}$, Christian et al., 2003; Christian and Petersen, 2005), the equivalent annual global LNOx production rate based on individual TROCCINOX thunderstorms is estimated (Sect. 4). The different LNOx production rates estimated in tropical and subtropical thunderstorms are investigated through a comparison of LINET measurements, e.g. frequency distributions of stroke peak currents and mean peak currents (Sect. 5). In addition, the lightning properties are compared with those in mid-latitude thunderstorms over Germany, where the same lightning location network (LINET) was set up in July 2005. Airborne $\mathrm{NO}_{\mathrm{x}}$ measurements over Germany are available from previous campaigns (Huntrieser et al., 1998, 2002), but not for July 2005 (Sect. 5). The results are discussed and summarised in Sects. 6-7. The present study is the first to our knowledge that investigates whether tropical, subtropical and midlatitude thunderstorms have different potentials to produce LNOx by combining lightning peak current measurements with airborne $\mathrm{NO}_{\mathrm{x}}$ and meteorological measurements.

\section{Data and model description}

For general information on the TROCCINOX field experiment, see the papers by Schumann et al. (2004), HH07 and SH07. The following subsections describe the airborne data obtained mainly from the research aircraft Falcon of the Deutsches Zentrum für Luft- und Raumfahrt
(DLR) as well as partly from the Russian M55 Geophysica aircraft (Sect. 2.1), lightning data from LINET, LIS and RINDAT (Sect. 2.2) and model simulations from FLEXPART (Sect. 2.3). In addition, we use data from two Sband Doppler radars in Bauru $\left(22.4^{\circ} \mathrm{S}, 49.0^{\circ} \mathrm{W}\right)$ and in Presidente Prudente $\left(22.1^{\circ} \mathrm{S}, 51.4^{\circ} \mathrm{W}\right)$ operated by the Instituto de Pesquisas Meteorológicas (IPMet). Two different radar reflectivity products are presented: surveillance Plan Position Indicator (PPI, range $450 \mathrm{~km}$ ) and $3.5 \mathrm{~km}$ Constant Altitude PPI (CAPPI, range $240 \mathrm{~km}$ ). The meteorological environment of tropical, subtropical and mid-latitude thunderstorms was characterised with analysis data (temperature, water vapour mixing ratio, pressure, wind velocity and direction) from the European Centre for Medium Range Weather Forecasts (ECMWF) with $3 \mathrm{~h}$ temporal resolution, $1^{\circ}$ horizontal resolution and 60 vertical levels. The equivalent potential temperature is calculated as described in HH07. The separation of tropical and subtropical air masses is based on meteorological data, as already discussed for the two selected flights of 4 and 18 February 2005 in HH07. The 4 and 18 February flights were classified as tropical and subtropical, respectively.

\subsection{Airborne instrumentation: Falcon and Geophysica}

Airborne measurements up to $12.5 \mathrm{~km}$ were carried out with the Falcon, which was equipped with DLR instruments to measure $\mathrm{NO}, \mathrm{NO}_{\mathrm{y}}, \mathrm{O}_{3}, \mathrm{CO}$ and $\mathrm{J}\left(\mathrm{NO}_{2}\right)$. The chemical instrumentation is the same as that used during several DLR field campaigns in the past (HH07). Position, altitude, temperature, humidity, pressure and the 3-dimensional wind vector $(u, v$ and $w)$ were measured with the standard Falcon meteorological measurement systems (Schumann et al., 1995). Wind and pressure were measured with a Rosemount flow angle sensor (model 858) at the Falcon's noseboom tip. The aerodynamic measurements were analysed according to an extensive in-flight calibration programme (Bögel and Baumann, 1991).

In addition, $\mathrm{NO}$ and $\mathrm{CO}$ measurements were obtained from the high-flying Geophysica aircraft $(\sim 20 \mathrm{~km})$ (Stefanutti et al., 2004). The SIOUX instrument, developed and operated by the DLR, measures the NO mixing ratio (chemiluminescence technique) with a time resolution of $1 \mathrm{~s}$, and an accuracy and precision of $10 \%$ and 5\%, respectively. The CO-TDL instrument (cryogenic Tunable Diode Laser technique) operated by the Istituto Nazionale di Ottica Applica/Consiglio Nazionale delle Ricerche (INOA/CNR), measures the $\mathrm{CO}$ mixing ratio with an averaging time of $5 \mathrm{~s}$, the accuracy and precision being 5\% and 2\%, respectively.

All flight altitude values refer to pressure height and all times to UTC (Coordinated Universal Time) time (see also HH07). 
Table 1. Positions of LINET sensors in Brazil (January-February 2005) and Germany (July 2005).

\begin{tabular}{lll}
\hline Country/Station Name & Latitude & Longitude \\
\hline Brazil & ${ }^{\circ} \mathrm{S}$ & ${ }^{\circ} \mathrm{W}$ \\
Marilia & 22.235 & 49.965 \\
Novo Horizonte & 21.466 & 49.226 \\
Bauru & 22.358 & 49.027 \\
Qurinhos & 22.951 & 49.896 \\
Araquara & 21.813 & 48.199 \\
Botucatu & 22.848 & 48.432 \\
& & \\
Germany & $\circ \mathrm{N}$ & ${ }^{\circ} \mathrm{E}$ \\
Ravensburg & 47.801 & 09.696 \\
Regensburg & 49.043 & 12.103 \\
Weissenburg & 49.019 & 10.960 \\
Berchtesgaden & 47.634 & 13.001 \\
Lahr & 48.365 & 07.828 \\
Karlsruhe & 49.093 & 08.426 \\
Basel & 47.561 & 07.969 \\
Bamberg & 49.880 & 10.914 \\
Weiden & 49.667 & 12.184 \\
Stegen & 48.076 & 11.139 \\
Passau & 48.572 & 13.424 \\
Garching & 48.269 & 11.674 \\
Peissenberg & 47.801 & 11.010 \\
Geretsried & 47.870 & 11.476 \\
Buchloe & 48.037 & 10.728 \\
Stadtbergen & 48.349 & 10.850 \\
Lichtenau & 47.881 & 11.080 \\
Lagerlechfeld & 48.181 & 10.840 \\
Oberpfaffenhofen & 48.087 & 11.280 \\
\hline
\end{tabular}

\subsection{Lightning measurements: LINET, LIS and RINDAT}

During the TROCCINOX field campaign from 21 January to 27 February 2005, the VLF/LF (5-300 kHz) lightning detection network LINET was used to monitor the local lightning distribution with high spatial resolution. LINET was set up by DLR in cooperation with IPMet. The network included six sensors from DLR to observe the area $19.5-24.5^{\circ} \mathrm{S}$ and $46.5-51.5^{\circ} \mathrm{W}$ (see Table 1). The average distance to the next closest sensor was $\sim 80 \mathrm{~km}$. For comparison of lightning characteristics, measurements from southern Germany in summer 2005 with 19 sensors (from both DLR and the University of Munich), monitoring the area $47-51^{\circ} \mathrm{N}$ and 5$14^{\circ} \mathrm{E}$, were also included in this study (Table 1 ). The average distance to the next closest sensor was $\sim 80 \mathrm{~km}$ in the outer region and $\sim 20 \mathrm{~km}$ in the inner region. The basically similar features of the LINET arrays in Germany and Brazil allows for comparison of the characteristics of thunderstorms systems in both regions (Schmidt et al., 2005).

The LINET system has been developed by the University of Munich and the sensor technology and measure- ment procedures have been described in detail by Betz et al. (2004), Schmidt et al. (2004, 2005), Betz et al. (2007a) and Schmidt (2007). For an overview of system characteristics see SH07. LINET continuously measures the transient magnetic components of VLF/LF emissions from lightning discharges. These signals are emitted by certain components of the flashes, and therefore a direct comparison with published flash statistics (e.g., IC/CG ratio) is not possible. At the current stage, VLF sources are considered separately. A routine algorithm to combine them into flashes is under development. However, a selected set of strokes were combined manually into flash "components" (nearby strokes within $<1 \mathrm{~s}$ ). These analyses indicate that LINET locates few VLF strokes per flash components, on average 3 and up to 9 (not shown).

It is known that the amplitude of a measured electromagnetic signal is proportional to the peak current (Uman et al., 1975; Rakov et al., 1992; Cummins et al., 1998; Orville, 1999; Jerauld et al., 2005; Schulz et al., 2005). Thus, the peak current of LINET strokes is estimated from the VLF pulse amplitude. The registered amplitude depends on the distance between the VLF pulse and the measuring LINET sensor. The registered pulse is normalised by the reciprocal value of the distance between pulse source and sensor, and averaged over all sensors that registered the VLF pulse. Owing to refined antenna techniques, optimised waveform handling and a shorter sensor base line of $<100 \mathrm{~km}$, a high detection efficiency of low peak currents is possible. The detection efficiency, stroke-current dependent, is highest in the LINET centre area $\left(2^{\circ} \times 2^{\circ}\right)$ with $>90 \%$ and decreases rapidly down to $30 \%$ towards the periphery (Betz et al., 2004, 2007a, b; Schmidt et al., 2007). Currents as low as $\sim 1-2 \mathrm{kA}$ can be detected by the system within the LINET centre area (periphery $\sim 5 \mathrm{kA}$ ). In comparison, most other VLF/LF lightning networks report only strokes $>5-10 \mathrm{kA}$ (Cummins et al., 1998).

In addition to LINET data, spaceborne measurements from LIS onboard the Tropical Rainfall Measurement Mission (TRMM) satellite (Christian et al., 1999; Thomas et al., 2000; Boccippio et al., 2002) were used to estimate the total regional flash density (sum of CG and IC flashes) over the TROCCINOX area. For an overview of system characteristics see SH07. The sensor can view any area on its footprint for a period of $90 \mathrm{~s}$. This is long enough to estimate the flashing rate of most thunderstorms in the field of view during the passage (see http://thunder.msfc.nasa.gov/lis/). At noon the detection efficiency is $73 \pm 11 \%$ and at night $93 \pm 4 \%$ (Boccippio et al., 2002). Here we used LIS science products (total count of flashes) from the "LIS space time domain search" (see http://thunder.nsstc.nasa.gov/lightning-cgi-bin/ lis/LISSearch.pl). A recent comparison between LIS and LINET data showed a good agreement between two systems that are based on completely different measurement techniques (Schmidt et al., 2005). Here LIS data for one overpass on 4 February 2005 were compared with LINET data (see 
Sect. 4.5). LNOx estimates per LINET stroke were scaled up with LIS observations to provide an estimate of the regional and global strength of the LNOx production.

LINET data were also compared with data from the operational Brazilian lightning detection network RINDAT (see http://www.rindat.com.br/). Like LINET, RINDAT operates in the VLF/LF range. The detection efficiency for strokes with peak currents above $10 \mathrm{kA}$ is $80-90 \%$ and the location accuracy is $0.5-2.0 \mathrm{~km}$ (Pinto and Pinto, 2003). The RINDAT system mainly registers CG flashes. A recent comparison between LINET and RINDAT strokes indicates reasonable agreement for CG strokes when LINET peak currents are above $12 \mathrm{kA}$ (Schmidt et al., 2005); see further comparisons in Sect. 3.

\subsection{Transport modelling: FLEXPART}

The distribution of LNOx in the vicinity of thunderclouds was simulated with the Lagrangian particle dispersion model FLEXPART. General information on FLEXPART used for TROCCINOX is given in HH07. The model has mainly been used for studying long-range air pollution transport (e.g. Stohl et al., 2003a, b; Huntrieser et al., 2005), but also to investigate LNOx transport (Stohl et al., 2003b; Beirle et al., 2006; Cooper et al., 2006).

The LNOx emissions used here as input for FLEXPART were based on lightning stroke data from the LINET system. LNOx was released uniformly in the vertical between $5 \mathrm{~km}$ (freezing level with negative charge centre) and $13 \mathrm{~km}$ altitude (cloud top) at the accurate horizontal position of observed VLF sources. Previous cloud model simulations for tropical continental thunderstorms (Pickering et al., 1998), indicate that LNOx was released mainly between 5 and $13 \mathrm{~km}$ increasing with altitude. However, because of the low resolution of the ECMWF wind fields $\left(0.5^{\circ}\right.$ horizontally $)$ used as input for FLEXPART, the distribution of lightning sources is assumed to be uniform in the vertical in the present study. A hundred particles were released per stroke, carrying the mass of LNOx produced (here set to $1 \mathrm{~kg}$ ). The convection scheme, used in these FLEXPART applications, transports the particles upward into the anvil, from where they follow trajectories computed with the ECMWF wind fields. No quantitative estimate of the amount of LNOx is possible from these simulations; they can, however, be used to estimate the extension of the LNOx field advected out of the anvil region.

\section{Observations during the field experiment}

An overview of the observations on the two selected TROCCINOX days, 4 and 18 February 2005 with thunderstorms in tropical and subtropical air masses, respectively, is given in HH07. Here we briefly focus on the performance of the lightning detection network LINET (Sect. 3.1) and on the

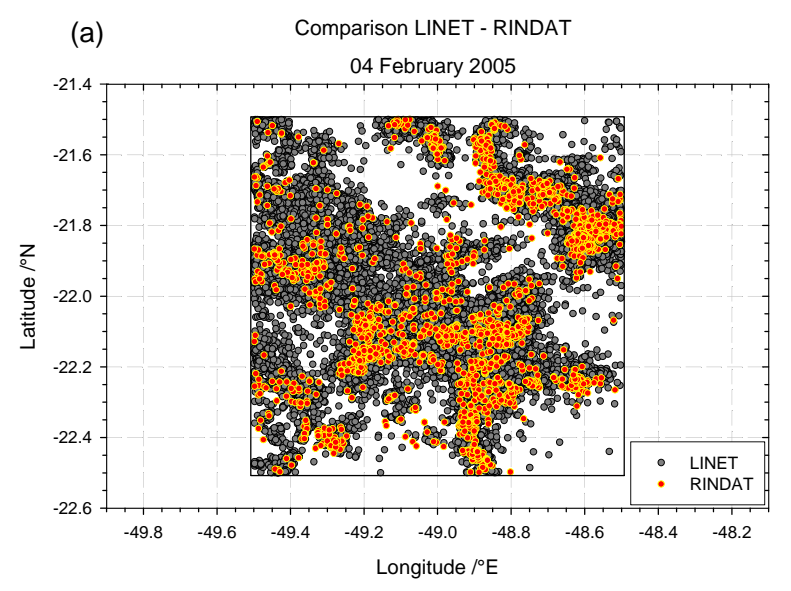

(b) 18 February 2005

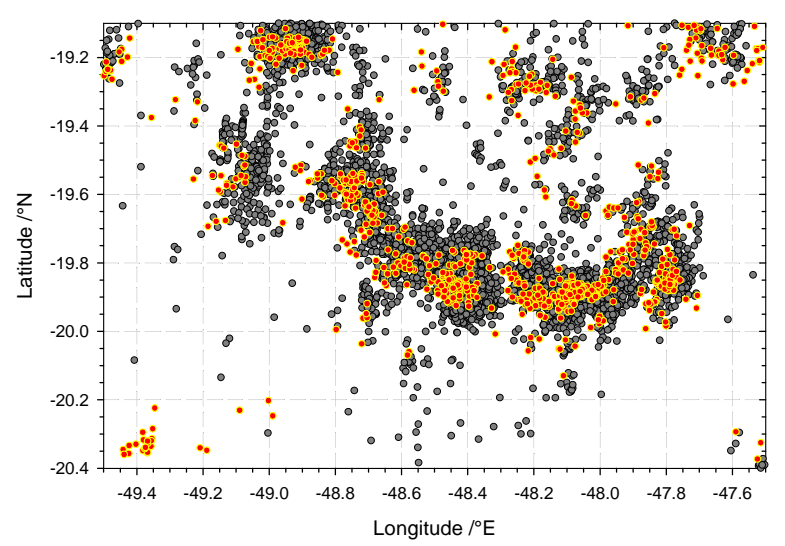

Fig. 1. Horizontal distributions of RINDAT and LINET strokes for the (a) 4 February 2005 in the centre area of the LINET detection network and for the (b) 18 February 2005 along the northern periphery, 00:00 UTC-24:00 UTC.

representation of the Falcon measurements in the anvil outflow (Sect. 3.2).

\subsection{Performance of LINET compared with RINDAT}

To evaluate the performance of the LINET system in more detail, a comparison with the operational lightning detection network in Brazil (RINDAT) was carried out for 4 and 18 February 2005. Horizontal distributions of RINDAT and LINET strokes were compared for the LINET centre area on 4 February 2005 (Fig. 1a), and for the northern LINET periphery area on 18 February 2005 (Fig. 1b), 00:00 UTC24:00 UTC. Overall, a general agreement was found, but with a slight shift of RINDAT strokes to the west compared with LINET strokes, especially in Fig. 1b. In some areas the density of LINET strokes was much larger than of RINDAT strokes (probably because IC strokes and strokes with low peak are not registered by RINDAT). The correlations between LINET and RINDAT peak currents (absolute values) 
(a) 04 February 2005

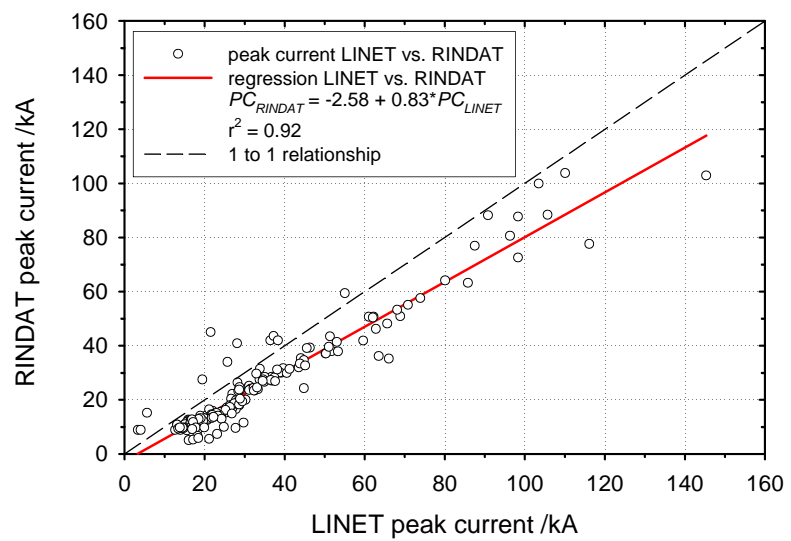

(b) 18 February 2005

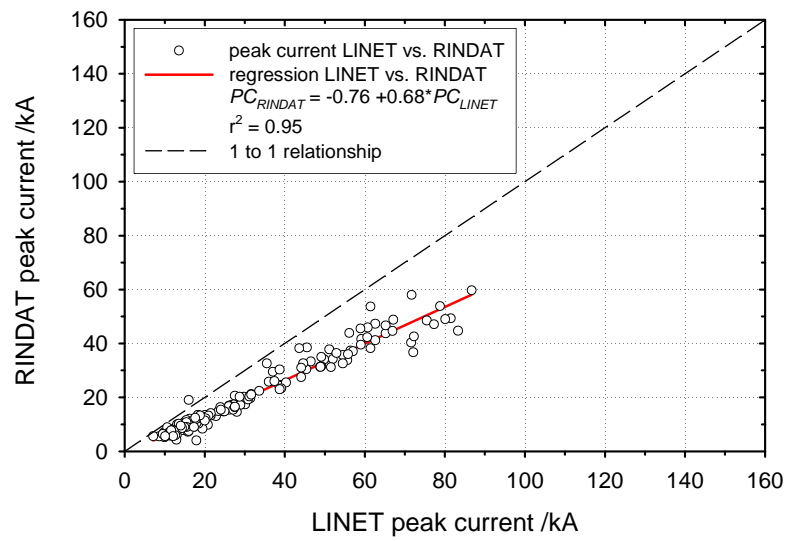

Fig. 2. Correlation between LINET and RINDAT peak currents $(P C)$ for 222 and 173 selected strokes on (a) 4 and (b) 18 February 2005, respectively, in the areas shown in Fig. 1a-b.

for 222 and 173 selected strokes of 4 February $\left(21.5-22.5^{\circ} \mathrm{S}\right.$ and $48.5-49.5^{\circ} \mathrm{W}$ ) and 18 February (19.4-20.0 $0^{\circ} \mathrm{S}$ and 47.7$49.2^{\circ} \mathrm{W}$ ) are shown in Fig. $2 \mathrm{a}$ and $\mathrm{b}$, respectively. On 4 February only negative CG strokes were compared. On 18 February no separation between CG and IC strokes was possible for the LINET data, owing to the location of the selected strokes along the northern periphery area. LINET strokes were therefore compared with both positive and negative CG strokes from RINDAT. About $10 \%$ of the selected LINET strokes were positive ones. The strokes shown in Fig. 2 were selected manually to represent peak current values over the entire current range. LINET peak currents above 13-14 kA are in general also detected by RINDAT, occasionally even LINET peak currents down to $7 \mathrm{kA}$. The slope (0.83) seen in Fig. 2a indicates that a $20 \mathrm{kA}$ LINET stroke is on average registered as $14 \mathrm{kA}$ by RINDAT. In Fig. $2 \mathrm{~b}$ the slope is slightly lower (0.68) owing to the lower LINET detection efficiency along the northern periphery. In addition, the mean peak current is higher for LINET strokes (35 kA in Fig. 2a and $31 \mathrm{kA}$ in Fig. 2b) than for RINDAT strokes (27 kA in Fig. $2 \mathrm{a}$ and $20 \mathrm{kA}$ in Fig. 2b). The high correlation coefficient $\left(r^{2}=0.92\right.$ and 0.95 , respectively) between the peak currents of the two systems indicates a good agreement in general. Lower RINDAT CG+ peak currents $(<30 \mathrm{kA})$ are frequently registered as IC + by LINET $(\sim 40 \%)$ and stronger RINDAT CG- peak currents $(>100 \mathrm{kA})$ are frequently registered as IC- by LINET $(\sim 40 \%)$. This finding can be compared with results from EULINOX in Germany where flashes registered with a LPATS system (same technology as used for RINDAT) were compared with the French Office National d'Etudes et de Recherches Aérospatiales (ONERA) VHF interferometer measurements. Théry (2001) found that $61 \%$ of the positive LPATS flashes (those of low intensity) and $32 \%$ of the negative LPATS flashes were in fact IC flashes. A recent study by Pinto et al. (2007) also confirmed that a large percentage of the positive CG flashes registered by RINDAT over Brazil are in fact IC flashes. For the analysed dataset we found that weak positive RINDAT peak currents $(<10 \mathrm{kA})$ are occasionally $(<10 \%)$ registered as negative strokes by LINET.

3.2 $\mathrm{NO}_{\mathrm{x}}$ in the anvil outflow derived from aircraft measurements

In HH07 it was briefly discussed whether the outflow altitude where LNOx maximises was reached with the Falcon aircraft (important question for comparison with results from other field campaigns and for further calculations in Sect. 4). It was concluded that this altitude was reached with certainty on 18 February, but on 4 February the Falcon measured the largest mixing ratios in the uppermost flight levels so that larger mixing ratios at higher altitudes inside the anvil cannot be excluded. Therefore, for the latter day measurements from the high-flying Geophysica in the upper part of this thunderstorm were briefly analysed as discussed below.

The Falcon measurements in two of the anvils of 4 February (anvil 1a and 5a, listed in Table 2a and described in Sect. 4.1) can be compared with coincident measurements with the high-flying Geophysica. The Geophysica penetrated anvil 1a during ascent between 15.9 and $16.6 \mathrm{~km}$ (penetration at flight time: $67070-67298 \mathrm{~s}$, at position: 21.3 $21.5^{\circ} \mathrm{S}$ and $49.1-49.3^{\circ} \mathrm{W}$ ) and anvil $5 \mathrm{a}$ during descent between 17.2 and $16.5 \mathrm{~km}$ (penetration at flight time: 66569 $66696 \mathrm{~s}$, at position: $21.8-21.9^{\circ} \mathrm{S}$ and $\left.48.5-48.7^{\circ} \mathrm{W}\right)$. The mean NO mixing ratios in anvil $1 \mathrm{a}$ and anvil $5 \mathrm{a}$ were 0.30 and $0.35 \mathrm{nmol} \mathrm{mol}^{-1}$, respectively. The mean anvil-NO mixing ratio is the mean value of all NO $1 \mathrm{~s}$-values measured between the entrance and exit of the anvil (determined from the distinct increase and decrease in the NO mixing ratio). The mean mixing ratios measured by the Geophysica between $\sim 16-17 \mathrm{~km}$ altitudes are distinctly lower than the NO mixing ratios measured by the Falcon at lower altitudes (10.6-10.7 km): 0.80 and $1.16 \mathrm{nmol} \mathrm{mol}^{-1}$ in anvil 1a and anvil 5a, respectively. The Geophysica measurements in 
Table 2a. Estimates of horizontal LNOx mass flux $F_{\mathrm{LNOx}}$, LINET stroke rate $R_{\mathrm{LINET}}$, LNOx production rate per LINET stroke and per LIS flash $P_{\mathrm{LNOx}}$, and global LNOx production rate per year $G_{\mathrm{LNOx}}$.

\begin{tabular}{|c|c|c|c|c|c|c|c|c|c|c|c|c|}
\hline $\begin{array}{l}\text { Flight } \\
\text { and Anvil } \\
\text { Penetration / } \\
\text { tropical (t) } \\
\text { or subtropical (s) }\end{array}$ & $\begin{array}{l}\text { Entry and Exit } \\
\text { Time (UTC), s }\end{array}$ & $\begin{array}{l}\text { Pressure } \\
\text { Altitude, } \\
\mathrm{km}\end{array}$ & $\begin{array}{l}\text { Mean, } \\
\chi_{L N O x} \\
\mathrm{nmol} \\
\mathrm{mol}^{-1}\end{array}$ & $\begin{array}{l}\left|V_{a}-V_{s}\right|^{1}, \\
\mathrm{~m} \mathrm{~s}^{-1}\end{array}$ & $\begin{array}{l}\rho_{a}, \mathrm{~kg} \\
\mathrm{~m}^{-3}\end{array}$ & $\begin{array}{l}\Delta x, \\
\mathrm{~km}\end{array}$ & $\Delta z, \mathrm{~km}$ & $\begin{array}{l}F_{\text {LNOx }}^{2} \\
\mathrm{~g}(\mathrm{~N}) \mathrm{s}^{-1}\end{array}$ & 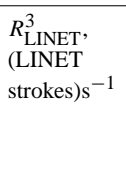 & 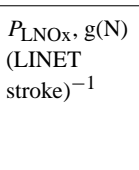 & $\begin{array}{l}P_{\text {LNOx }}, g(\mathrm{~N}) \\
\left(_{\text {LIS flash })^{-1}}\right.\end{array}$ & $\begin{array}{l}G_{\mathrm{LNOx}}, \\
\operatorname{Tg}(\mathrm{N}) \mathrm{a}^{-1}\end{array}$ \\
\hline $040205 \_1 \mathrm{a}(\mathrm{t})$ & $66199-66433$ & 10.6 & 0.76 & 6.5 & 0.36 & 35 & 4 & 120 & 0.055 & 2205 & 1103 & 1.5 \\
\hline 040205_5a (t) & $67682-67833$ & 10.7 & 1.10 & 5.9 & 0.36 & 25 & 4 & 113 & 0.054 & 2082 & 1041 & 1.4 \\
\hline \multirow[t]{2}{*}{$040205 \_2 b(t)$} & $69905-70169$ & 10.1 & 0.57 & 9.2 & 0.39 & 45 & 4 & 178 & 0.061 & 2914 & 1457 & 2.0 \\
\hline & mean tropical ${ }^{4}$ & & & & & & & & & 2400 & 1200 & 1.6 \\
\hline 180205b_I (s) & $74056-74209$ & 10.6 & 0.42 & 17.7 & 0.36 & 28 & 3 & 109 & 0.025 & 4258 & 2129 & 3.0 \\
\hline 180205b_II (s) & $74453-74623$ & 10.7 & 0.18 & 20.0 & 0.36 & 33 & 3 & 62 & 0.025 & 2430 & 1215 & 1.7 \\
\hline 180205b_III (s) & $75013-75186$ & 10.1 & 0.65 & 12.2 & 0.39 & 32 & 3 & 143 & 0.025 & 5623 & 2811 & 3.9 \\
\hline $180205 b$ IV (s) & $75601-75761$ & 10.1 & 0.21 & 20.0 & 0.39 & 30 & 3 & 71 & 0.025 & 2792 & 1396 & 1.9 \\
\hline 180205b_V (s) & $76102-76280$ & 9.4 & 0.39 & 11.9 & 0.41 & 33 & 3 & 91 & 0.025 & 3568 & 1784 & 2.5 \\
\hline \multirow[t]{3}{*}{ 180205b_VI (s) } & $76584-76757$ & 9.4 & 0.13 & 17.7 & 0.41 & 35 & 3 & 48 & 0.025 & 1876 & 938 & 1.3 \\
\hline & mean subtropical ${ }^{4}$ & & & & & & & & & 4483 & 2241 & 3.1 \\
\hline & relative max. error & & $\sim 50 \%$ & $\sim 50 \%$ & & $\sim 40 \%$ & $\sim 50 \%$ & $\sim 190 \%$ & $\sim 90 \%$ & $\sim 280 \%$ & $\sim 310 \%$ & $\sim 320 \%$ \\
\hline
\end{tabular}

${ }^{1}$ Horizontal anvil outflow velocity, calculated from values in Table $2 b$.

2 The horizontal LNOx mass flux out of the anvil, see Eq. (4).

${ }^{3}$ Only LINET strokes with peak currents $\geq 10 \mathrm{kA}$ were considered for an equivalent comparison between 040205 (strokes mainly inside the LINET centre) and 180205 b (strokes along LINET periphery).

4 The mean value for the tropical anvil penetrations $1 \mathrm{a}, 5 \mathrm{a}$ and $2 \mathrm{~b}$ of 4 February 2005 is given. The mean value for the subtropical anvil penetrations I, III, and V of 18 February 2005 (penetrations closest to the maximum anvil outflow) is given.

the anvils on 4 February indicate an increase in NO mixing ratios with decreasing altitude, opposite to the Falcon measurements. Hence the outflow level where NO mixing ratios maximise was likely to be located between the altitudes at which the Falcon and Geophysica penetrated the anvils. CO measurements from the Geophysica (personal communication P. Mazzinghi, INOA/CNR) can be used to determine this outflow level more precisely (on the assumtion that LNOx maximises where $\mathrm{CO}$ maximises). The vertical $\mathrm{CO}$ profile (ascent and descent in the vicinity of the selected anvils) shows enhanced mixing ratios mainly between $\sim 10-14 \mathrm{~km}$ altitude. The mixing ratios were rather constant throughout this layer, $\sim 130-140 \mathrm{nmol} \mathrm{mol}^{-1}$. The outflow level, where the $\mathrm{CO}$ mixing ratio maximises $\left(132-138 \mathrm{nmol} \mathrm{mol}^{-1}\right)$, was located between $\sim 12.0-12.5 \mathrm{~km}$, about $1.5-2 \mathrm{~km}$ above the Falcon penetration. At the levels where the Falcon penetrated the anvils (10.6-10.7 km), however, the CO mixing ratio $\left(132 \mathrm{nmol} \mathrm{mol}^{-1}\right)$ was similar to the lowest Geophysica $\mathrm{CO}$ mixing ratios in the outflow level. The Falcon data may therefore underestimate the mean NO mixing ratios in the selected anvils to a degree which cannot be quantified from the available dataset. These mean NO mixing ratios are needed for further calculations in the next section. Preliminary results from cloud-resolved modelling for the 4 February thunderstorms by Pickering et al. (2007) suggest that the anvil outflow NO maximum is located between 12 and $13 \mathrm{~km}$, which supports our estimates derived from the vertical $\mathrm{CO}$ profile.
Table 2b. Measured wind velocity and direction in the anvil outflow and at the steering level ${ }^{1}$.

\begin{tabular}{lcccc}
\hline $\begin{array}{l}\text { Flight and } \\
\text { Anvil } \\
\text { Penetration }\end{array}$ & $\begin{array}{c}\text { Measured } \\
\text { Wind } \\
\text { Direction } \\
\text { in Anvil } \\
\text { Outflow } \\
d_{a},{ }^{\circ}\end{array}$ & $\begin{array}{c}\text { Measured } \\
\text { Wind } \\
\text { Velocity in } \\
\text { Anvil } \\
\text { Outflow } \\
V_{a}, \mathrm{~m} \mathrm{~s}^{-1}\end{array}$ & $\begin{array}{c}\text { Wind } \\
\text { Direction } \\
\text { at Steering } \\
\text { Level }^{1} d_{s},{ }^{\circ}\end{array}$ & $\begin{array}{c}\text { Wind } \\
\text { Velocity } \\
\text { at } \\
\text { Steering } \\
\text { Level }^{1} V_{s}, \\
\mathrm{~m} \mathrm{~s}^{-1}\end{array}$ \\
\hline 040205_1a & $71 \pm 31$ & $5.2 \pm 1.7$ & 160 & 3.9 \\
040205_5a & $182 \pm 50$ & $3.9 \pm 2.7$ & 280 & 3.9 \\
040205_2b & $107 \pm 23$ & $6.9 \pm 2.0$ & 350 & 3.7 \\
180205b_I & $283 \pm 12$ & $16.6 \pm 4.1$ & 185 & 4.3 \\
180205b_II & $277 \pm 4$ & $19.4 \pm 2.3$ & 185 & 4.3 \\
180205b_III & $274 \pm 11$ & $11.5 \pm 5.3$ & 185 & 4.3 \\
180205b_IV & $279 \pm 5$ & $19.2 \pm 1.3$ & 185 & 4.3 \\
180205b_V & $268 \pm 10$ & $11.6 \pm 5.7$ & 185 & 4.3 \\
180205b_VI & $278 \pm 5$ & $16.9 \pm 1.4$ & 185 & 4.3 \\
\hline
\end{tabular}

1 The wind at the steering level $\sim 3 \mathrm{~km}(\sim 700 \mathrm{hPa})$ determines the mean motion of a thunderstorm cell.

\section{Estimate of the LNOx production rate per flash and per year}

In this section the measurements in selected tropical and subtropical thunderstorms of 4 and 18 February 2005 are discussed in more detail. The spatial and temporal distributions of LINET strokes are presented (Sect. 4.1). The contribution from observed LINET strokes to measured anvil$\mathrm{NO}_{\mathrm{x}}$ mass and the resulting LINET stroke rates are estimated (Sect. 4.2). Furthermore, the contribution of $\mathrm{BL}^{-\mathrm{NO}_{\mathrm{x}}}$ and 
Method to estimate the global annual LNOx production based on field measurements

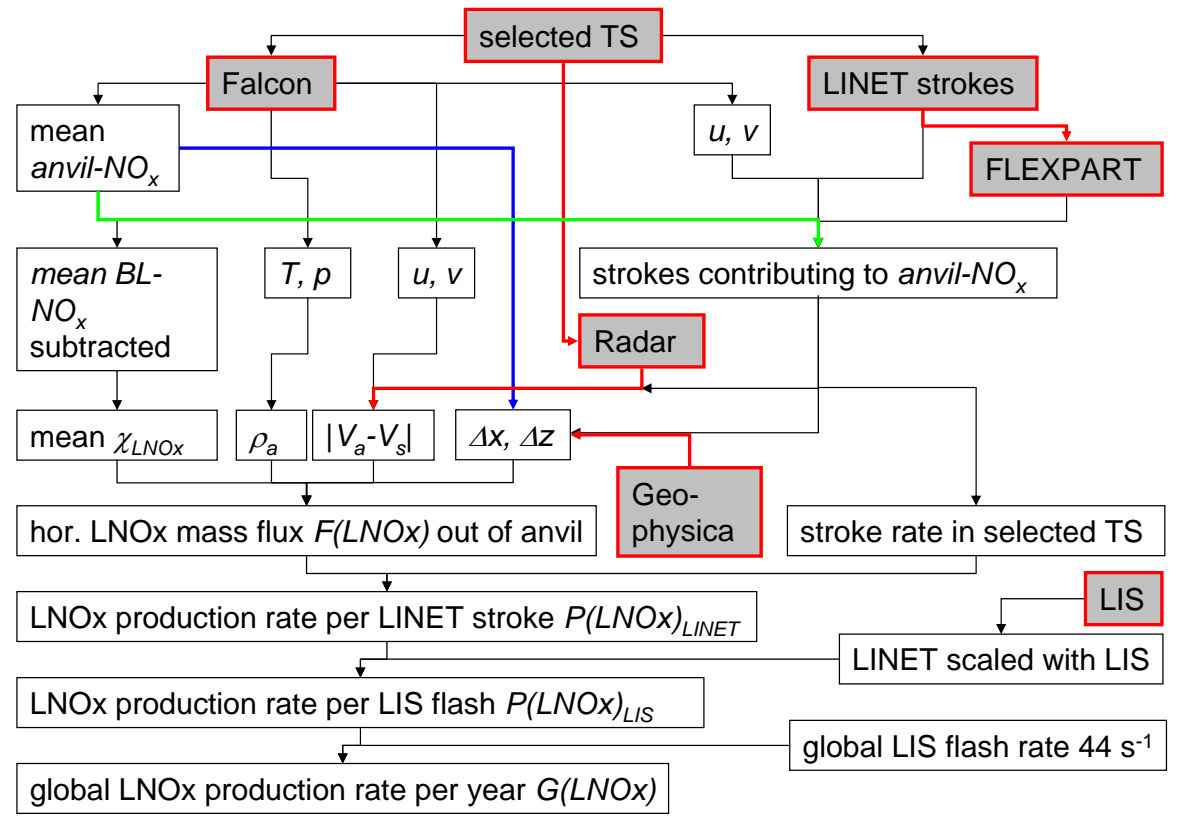

Fig. 3. Flow chart showing the introduced method to estimate the annual global LNOx production rate from TROCCINOX field measurements (Falcon, Geophysica, LINET, Radar) combined with LIS data and model simulations (FLEXPART) of the selected thunderstorms (TS) all indicated with grey background. Different line colours are used to avoid misunderstanding of the flow direction at line intersections.

LNOx to measured anvil- $\mathrm{NO}_{\mathrm{x}}$ is estimated (Sect. 4.3). The horizontal LNOx mass flux rate out of the anvils is calculated by means of estimated LNOx mixing ratios and horizontal outflow wind velocities from the flights combined with the size of the vertical cross-section of the anvils (Sect. 4.4). LNOx nitrogen mass flux rates $\left(\mathrm{g} \mathrm{s}^{-1}\right)$ and LINET stroke rates (strokes $\mathrm{s}^{-1}$ ) are combined to estimate the production rate of LNOx (in $\mathrm{g}$ of nitrogen mass or number of $\mathrm{NO}_{\mathrm{x}}$ molecules) per LINET stroke and per LIS flash (Sect. 4.5). Finally, the annual global LNOx nitrogen mass production rate is estimated (in $\mathrm{Tg} \mathrm{a}^{-1}$ ). Figure 3 gives an overview of these different steps described in detail in the following subsections, starting with the selection of a thunderstorm (TS) and ending with an estimate of the annual global LNOx production rate $\mathrm{G}(\mathrm{LNOx})$.

\subsection{Spatial and temporal LINET stroke distributions}

The spatial distributions of LINET strokes of 4 and 18 February 2005 are shown in Fig. 4a and b, respectively. For the selected thunderstorms, strokes occurring before the penetrations by the Falcon are highlighted in colour. Superimposed is the Falcon track showing the successful, repeated penetrations of the subtropical thunderstorm system of 18 February, and the zigzag pattern between the tropical thunderstorms (labelled 1a, 5a and 2b) of 4 February. The time periods of the anvil penetrations are listed in Table 2a. The direction of the thunderstorm movement (red arrows in Fig. 4) is inferred from lightning data. The main wind direction in the anvil outflow (green arrows), as inferred from Falcon wind measurements, controls the transport of LNOx out of the anvils. On 4 February the prevailing wind direction in the flight level (influenced by the Bolivian High, see Fig. 5c in HH07) varied between north-east and south-east in vicinity of anvil $1 \mathrm{a}$ and $2 \mathrm{~b}$, and was from the south-west in the vicinity of anvil 5a. The $\mathrm{NO}_{\mathrm{x}}$ mixing ratio along the flight track is also superimposed in Fig. 4. Elevated mixing ratios exceeding $0.6 \mathrm{nmol} \mathrm{mol}{ }^{-1} \mathrm{NO}_{\mathrm{x}}$ were frequently measured in the anvil outflow downwind of nearby lightning strokes.

The selected thunderstorms of 4 and 18 February occurred in the centre and at the northern border line of the LINET network, respectively. Because of a higher sensitivity in the network centre, the fraction of strokes with low currents $(<10 \mathrm{kA})$ was much higher on 4 February $(87 \%)$ than on 18 February (45\%). For the latter thunderstorm system no separation between IC and CG strokes was possible because of the large distance from the centre. For an adequate comparison of the stroke rates in these storms, it was necessary to restrict comparisons to higher stroke peak currents $(\geq 10 \mathrm{kA})$ which were observed with about the same detection efficiency, independently of their location within the LINET network. On 4 February strokes were widespread with some at the LINET periphery. LINET strokes were therefore compared with LIS flashes and RINDAT strokes to determine the 
(a)

LINET stroke distribution - 040205

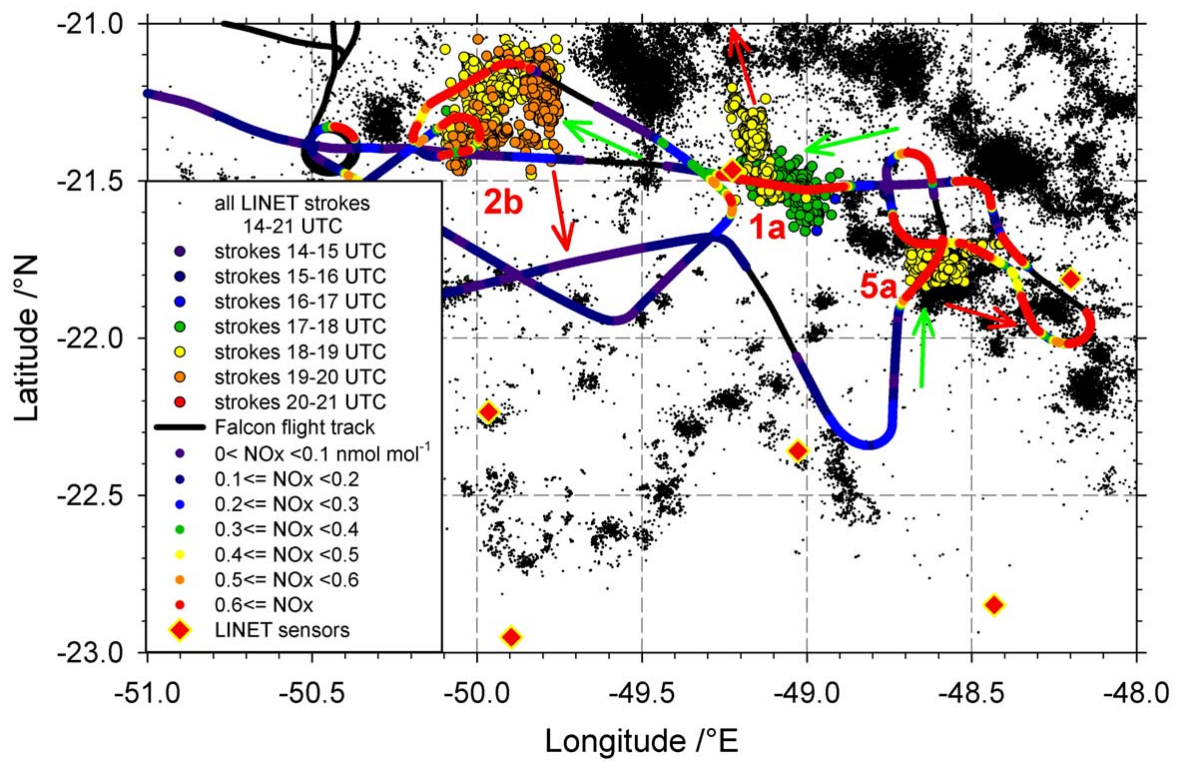

(b) $\quad$ LINET stroke distribution - 180205

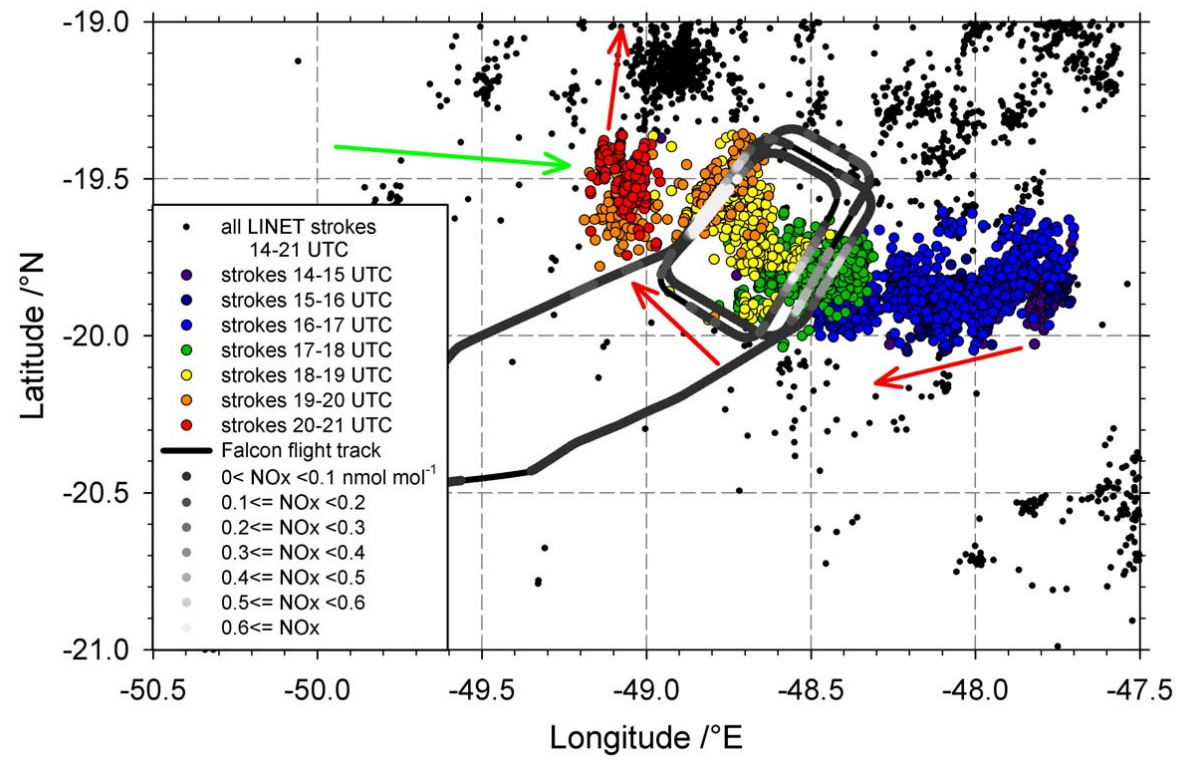

Fig. 4. Horizontal distributions of LINET strokes on (a) 4 and (b) 18 February 2005. All strokes registered before the Falcon penetration within the selected thunderstorm systems on 4 February (tropical: labelled 1a, 5a and 2b) and 18 February (subtropical) are coloured. Falcon flight paths and $\mathrm{NO}_{\mathrm{x}}$ mixing ratios are superimposed (colour/grey scale). The red arrows indicate the direction of the storm motion and the green arrows the main wind direction in the anvil outflow. In addition, the positions of the 6 LINET sensors listed in Table 1 are indicated in (a).

detection efficiency of the LINET system relative to the other two systems. The change in detection efficiency for these selected LINET strokes towards the LINET periphery was only minor $(<10 \%)$ compared with the other two systems and not considered further.

The temporal distributions of LINET stroke rates in the selected thunderstorms for peak currents $\geq 10 \mathrm{kA}$ are presented in Fig. 5. The storms of 4 February were mainly in a mature stage during the aircraft passage. In comparison, the longlived storm system of 18 February was in a decaying stage and probed long after the peak lightning activity (first lightning was registered already $6 \mathrm{~h}$ before the first penetration). 
LINET stroke distributions

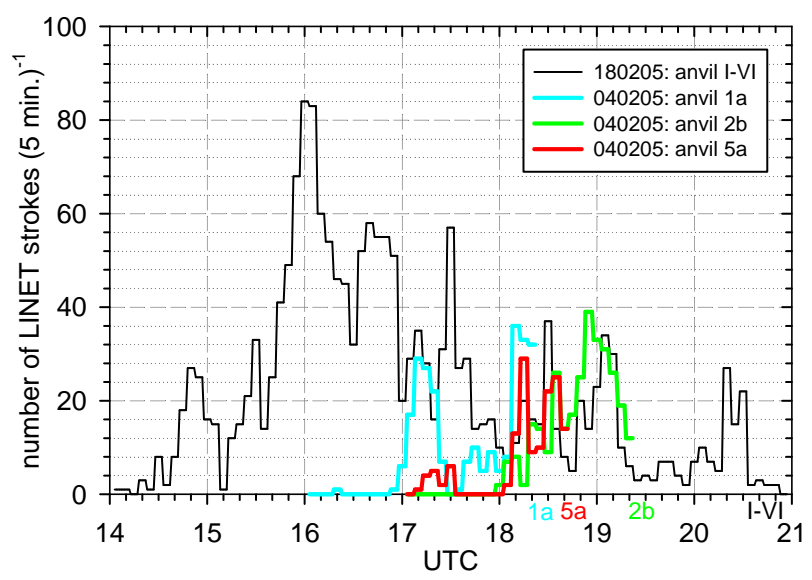

Fig. 5. Time series of LINET stroke rates for the selected thunderstorms (only strokes with peak currents $\geq 10 \mathrm{kA}$ considered). On 4 February 2005, stroke rates in the investigated thunderstorms (active) are shown from storm initiation until penetration (tropical: labelled 1a, 5a and 2b). On 18 February 2005, the stroke rate within the selected thunderstorm system (subtropical) is shown from storm initiation until decay. The repeated penetration started first at 20:34 UTC (labelled I-VI) when the lightning activity decayed.

\subsection{Contribution of LNOx to anvil- $\mathrm{NO}_{\mathrm{x}}$ and determining LINET stroke rates}

For evaluation of the LNOx production rate per stroke, it is necessary to estimate which of the LINET strokes during the storm lifetime contributed to the measured anvil- $\mathrm{NO}_{\mathrm{x}}$ enhancement and its horizontal and vertical extension. This is a very difficult task which might be best performed by using cloud-scale modelling. First cloud-resolving model simulations have been performed for selected TROCCINOX storms of 4 February 2005 by Chaboureau et al. (2007) and by Pickering et al. (2007) but cloud-resolving simulations are presently not available for the thunderstorm system of 18 February 2005. Instead we make use of FLEXPART lightning tracer simulations, as explained in Sect. 2.3. The simulations follow lightning tracers from the horizontal LINET stroke distributions (Fig. 4b) using ECMWF wind fields. For the long-lived thunderstorm case of 18 February, ambient wind velocities were strong and LNOx was advected far downwind. The ECMWF wind agrees well with Falcon measurements of wind velocity and direction, except in the core of the anvil penetrations (Fig. 6). As shown later in this section, comparison of the ECMWF wind fields and FLEXPART results with radar and airborne wind and anvil- $\mathrm{NO}_{\mathrm{x}}$ observations, as indicated in Fig. 3, supports the validity of the FLEXPART simulations of the 18 February thunderstorm system, in spite of the coarse horizontal resolution $\left(0.5^{\circ}\right)$ of the ECMWF wind velocity fields used.
For the thunderstorm system of 18 February, a time sequence of FLEXPART lightning tracer simulations (Fig. 7) indicates a rather fast development of an elongated area with enhanced LNOx downwind of the storm system, following the wind in the upper troposphere (UT). Tracer distributions for six different simulations are shown in this figure (output resolution: $30 \mathrm{~min}$ and 0.08 degrees, horizontal crosssections at $10 \mathrm{~km}$ altitude corresponding to the flight level) considering transport of emissions from strokes in various time intervals. The simulated tracer distributions may be compared with the anvil- $\mathrm{NO}_{\mathrm{x}}$ observations from the Falcon (Fig. 4b). Only the last four simulations (Fig. 7c-f) indicate distinctly enhanced LNOx along the right hand side anvil transect, as observed by the Falcon. Furthermore, mixing ratios in the left hand side transects, closer to the core, were twice as high as in the right hand side transects. Given the measured UT wind velocity of 15 to $20 \mathrm{~m} \mathrm{~s}^{-1}$, it is clear that strokes that occurred between 19:00-19:30 UTC (along the left hand side anvil transect, $49.7-49.8^{\circ} \mathrm{W}$ ) or earlier do not contribute to the anvil- $\mathrm{NO}_{\mathrm{x}}$ enhancement observed along the right hand side anvil transect. The air with enhanced LNOx is advected further downwind to the right in Fig. 7d-f. Only strokes after 19:30 and before 20:55 UTC (when the storm decayed) (Fig. 7c) were therefore considered to have contributed to the observed anvil- $\mathrm{NO}_{\mathrm{x}}$. During this $85 \mathrm{~min}$ period about 130 strokes with peak currents $\geq 10 \mathrm{kA}$ were detected, corresponding to a stroke rate of 0.025 strokes s $^{-1}$ (Table 2a).

For the 18 February 2005 thunderstorm system, the horizontal extension $(\Delta x)$ of FLEXPART lightning tracer in Fig. 7c, perpendicular to the wind direction (see Fig. 4b), was estimated to be $\sim 30-35 \mathrm{~km}$. This width agrees well with the extension of the flight path segment with enhanced $\mathrm{NO}_{\mathrm{x}}$ observed during the single anvil transects $(28-35 \mathrm{~km})$; see the grey scale along the flight track in Fig. $4 \mathrm{~b}$ and Table 2. This parameter $(\Delta x)$ will be used to estimate the horizontal LNOx mass flux out of the anvil in Sect. 4.4.

Finally, a radar image of the 18 February thunderstorm system (Bauru radar, elevation angle $0^{\circ}$ ), indicates a pronounced, elongated structure of the storm system (Fig. 8), similar to the FLEXPART result at $10 \mathrm{~km}$ altitude. The 18 February thunderstorm system is located in the upper, northern domain of the radar range, about $240 \mathrm{~km}$ from the radar site. Unfortunately, the radar information is sparse in this region and no more detailed data are available since the domain is out of the quantification range where volumetric data are collected.

For the thunderstorms of 4 February, no FLEXPART simulations were performed since the storms just developed about one hour before the penetrations and this time was considered too short for realistic simulations. In addition, the ambient UT wind velocities were low $\left(4-7 \mathrm{~m} \mathrm{~s}^{-1}\right)$ and LNOx remained in the vicinity of the storms. Instead, as indicated in Fig. 3, the LNOx production rate per stroke and the width $\Delta x$ were estimated from a combination of horizontal LINET 


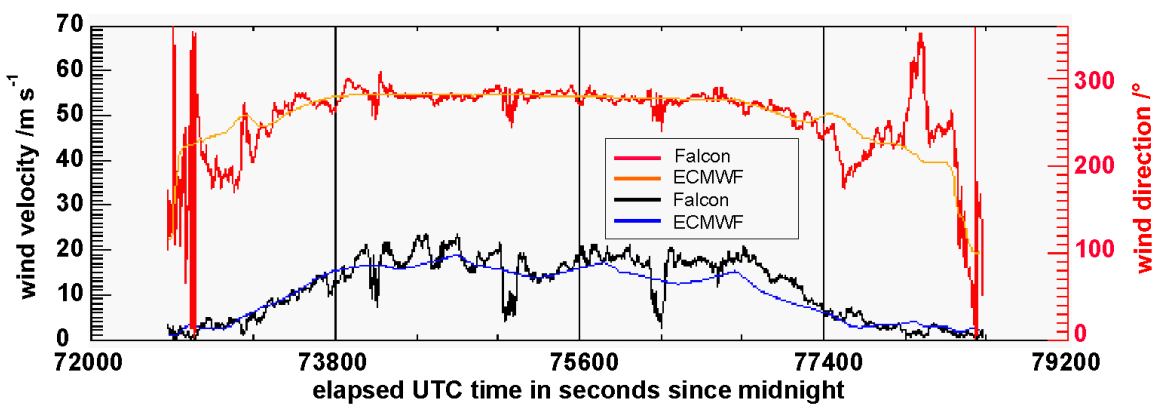

Fig. 6. Comparison between Falcon and ECMWF wind velocity (in black and blue, respectively) and wind direction (in red and orange, respectively) for the flight on 18 February 2005.

stroke distributions, radar images, Falcon wind and anvil$\mathrm{NO}_{\mathrm{x}}$ observations. The average altitude (arithmetical mean) of all IC strokes (Table 4a) in anvil $1 \mathrm{a}(10.0 \mathrm{~km})$ and anvil 5a $(11.6 \mathrm{~km})$ was below or just above the flight level $(10.6 \mathrm{~km}$ and $10.7 \mathrm{~km}$, respectively; see Table $2 \mathrm{a}$ ), indicating that the majority of LNOx, produced by the observed strokes left the anvil at about the flight level.

It is assumed that all LINET strokes observed in the vicinity of these storms between storm initiation and Falcon penetration (coloured in Fig. 4a) contributed to the observed anvil- $\mathrm{NO}_{\mathrm{x}}$ (Fig. 4a). (This is a working hypothesis with large uncertainties, which cannot be quantified without cloud-model simulations.) For comparison with the 18 February case, only the number of strokes with peak currents $\geq 10 \mathrm{kA}$ is counted. In anvil $1 \mathrm{a}$ about 278 strokes were registered between 16:55 and 18:20 UTC, in anvil 5a about 130 strokes were registered between 18:05 and 18:45 UTC and in anvil $2 \mathrm{~b}$ about 311 strokes were registered between 17:55 and 19:20 UTC; see Fig. 5, which corresponds to the following stroke rates: $0.055,0.054$ and 0.061 strokes $\mathrm{s}^{-1}$, respectively (see Table 2a).

For each of the three anvil penetrations, the width $(\Delta x)$ of the LNOx plume perpendicular to the wind direction was estimated from the horizontal LINET stroke distribution, from the anvil- $\mathrm{NO}_{\mathrm{x}}$ observations (Fig. $4 \mathrm{a}$ ) and from the radar images at the time of the penetrations (shown only hourly in Fig. 9). The $\Delta x$ values are $\sim 35, \sim 25$ and $\sim 45 \mathrm{~km}$ for anvils $1 \mathrm{a}, 5 \mathrm{a}$ and $2 \mathrm{~b}$, respectively (see Table $2 \mathrm{a}$ ).

\subsection{Contribution of $\mathrm{BL}-\mathrm{NO}_{\mathrm{x}}$ to anvil- $\mathrm{NO}_{\mathrm{x}}$}

The boundary layer (BL) contribution $\left(\chi_{\mathrm{BL}-\mathrm{NOx}}\right)$ to the $\mathrm{NO}_{\mathrm{x}}$ mixing ratio in the anvil $\left(\chi_{\text {Anvil-NOx }}\right)$ is derived from the correlation between $\mathrm{NO}_{\mathrm{x}}$ and $\mathrm{CO}$ mixing ratios in the $\mathrm{BL}$ and in the anvil. It is assumed, that BL air is transported upwards rapidly within strong, well-developed updrafts with little ambient mixing and without chemical loss of $\mathrm{NO}_{\mathrm{x}}$ and $\mathrm{CO}$. Hence, about the same $\mathrm{CO}$ mixing ratio is observed in the main anvil outflow $\left(\chi_{\text {Anvil-CO}}\right)$ as in the BL layer $\left(\chi_{\mathrm{BL}-\mathrm{CO}}\right)$ :

$\chi_{\text {Anvil }-\mathrm{CO}}=\chi_{\mathrm{BL}-\mathrm{CO}}$

and LNOx $\left(\chi_{\text {LNOx }}\right)$ is the difference between anvil- $\mathrm{NO}_{\mathrm{x}}$ and BL-NO : $^{2}$

$\chi_{\text {LNOx }}=\chi_{\text {Anvil }-\mathrm{NOx}}-\chi_{\mathrm{BL}-\mathrm{NOx}}$

These assumptions are supported by cloud-model simulations (Pickering et al., 1992; Thompson et al., 1997; Ott et al., 2007) and airborne thunderstorm observations (Dickerson et al., 1987; Hauf et al., 1995; Huntrieser et al., 1998, 2002; Höller et al., 1999; Lopez et al., 2006; Bertram et al., 2007; Koike et al., 2007). The ratio of $\mathrm{NO}_{\mathrm{x}}$ to $\mathrm{CO}$ in the $\mathrm{BL}$ $(<2 \mathrm{~km})$ is conserved during the rapid upward transport into the anvil:

$\chi_{\mathrm{BL}-\mathrm{NOx}} / \chi_{\mathrm{BL}-\mathrm{CO}}=\left(\chi_{\text {Anvil-NOx }}-\chi_{\mathrm{LNOx}}\right) / \chi_{\text {Anvil }-\mathrm{CO}}$

Vertical $\mathrm{NO}_{\mathrm{x}}, \mathrm{CO}$, and $\mathrm{O}_{3}$-profiles from the 18 February flight are shown in Fig. 10a. The CO mixing ratios, measured during the anvil penetrations, are in a similar range as those measured at $\sim 2 \mathrm{~km}$ altitude (see red box), supporting the assumption of rapid upward transport from the top of the $\mathrm{BL}$ into the anvils. Unfortunately, no $\mathrm{NO}_{\mathrm{x}}$ measurements are available below $3 \mathrm{~km}$ for this flight. Instead, $\mathrm{NO}_{\mathrm{x}}$ measurements in the BL were only available for ten TROCCINOX "fair weather" flights without active thunderstorms (Fig. 1a in $\mathrm{HH} 07) . \mathrm{NO}_{\mathrm{x}}$ and $\mathrm{CO}$ data from all available flights in the $\mathrm{BL}(<2 \mathrm{~km})$ were therefore used to estimate the average $\mathrm{BL} \mathrm{NO}_{\mathrm{x}}-\mathrm{CO}$ correlation. It can be justified that this relationship is representative, since $\mathrm{CO}$ mixing ratios in the $\mathrm{BL}$ were in the same range both for "thunderstorm" and for "fair weather" flights. The BL data were sampled mainly during take-off and landing near the campaign base. Hence, it was assumed that these values are representative for the entire BL covered by the selected flights.

In Fig. 10b the correlation between measured $\mathrm{NO}_{\mathrm{x}}$ and $\mathrm{CO}$ for the Falcon flight of 18 February is shown (black dots). Different types of air mass origin (Pacific, Amazon basin, anvil and background), as discussed in $\mathrm{HH} 07$, are 

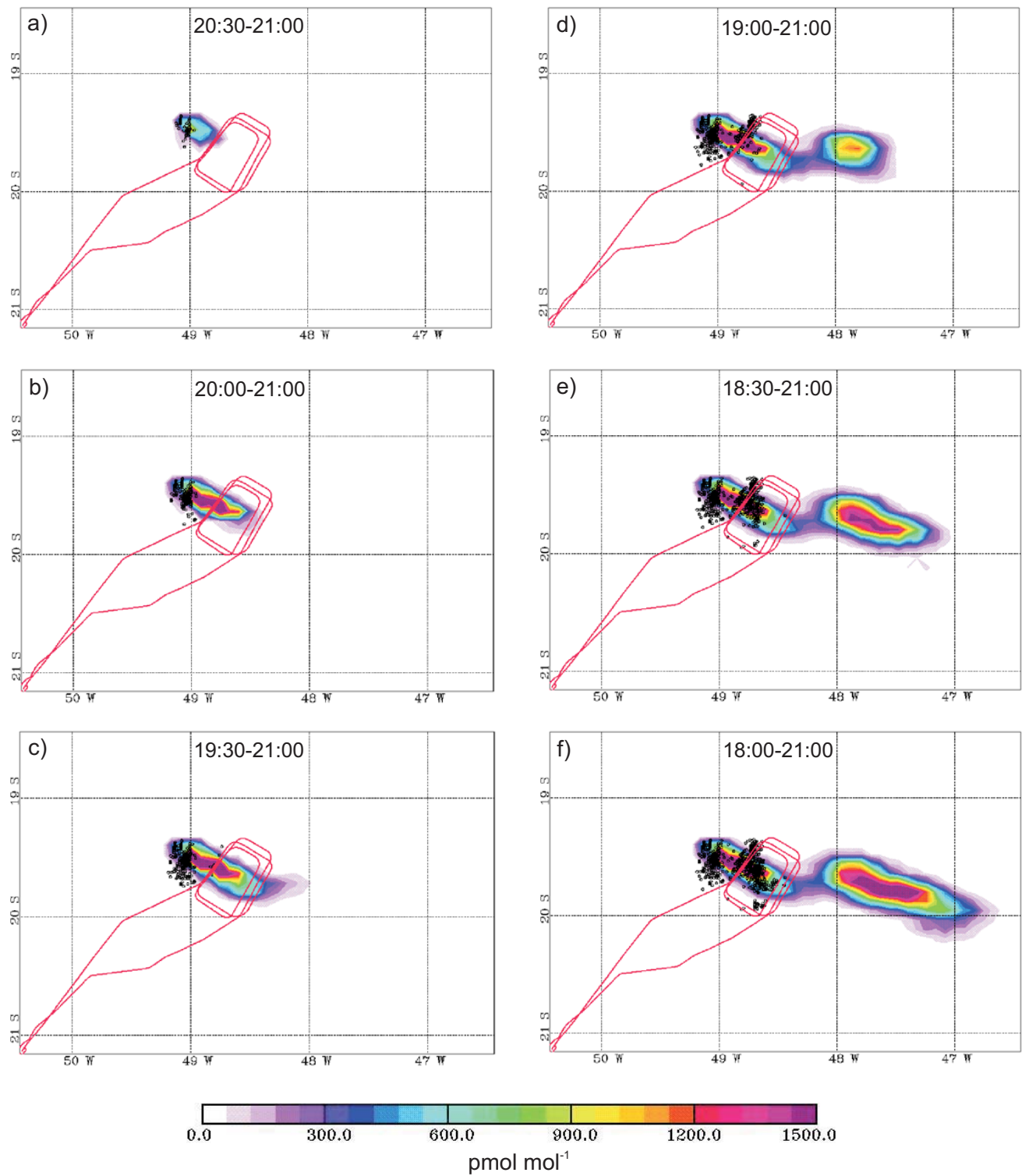

Fig. 7. FLEXPART lightning tracer simulations $\left(\mathrm{NO}_{\mathrm{X}}\right.$ at $10 \mathrm{~km}$ in pmol mol${ }^{-1}$ ) for the 18 February 2005 subtropical thunderstorm system considering all LINET strokes (black dots) after (a) 20:30 UTC, (b) 20:00 UTC, (c) 19:30 UTC, (d) 19:00 UTC, (e) 18:30 UTC, (f) 18:00 UTC and until 21:00 UTC. The Falcon track is superimposed in red.

marked. The measured $\mathrm{NO}_{\mathrm{x}}$ mixing ratios were mainly below $0.2 \mathrm{nmol} \mathrm{mol}^{-1}$, except during the anvil penetrations. The average $\mathrm{NO}_{\mathrm{x}}-\mathrm{CO}$ correlation in the $\mathrm{BL}$ for all TROCCINOX flights (data from Fig. 1 in HH07) is also shown in Fig. 10b (red-yellow dots). Average CO mixing ratios during the anvil penetrations of the 18 and 4 February flights were $95-105$ and $105-115 \mathrm{nmol} \mathrm{mol}^{-1}$, respectively. From the measured BL-CO (90-120 $\left.\mathrm{nmol} \mathrm{mol}^{-1}\right)$ and the correlation, the average $\mathrm{BL}-\mathrm{NO}_{\mathrm{x}}$ mixing ratio and its standard deviation (std) were estimated to be $0.11 \pm 0.07 \mathrm{nmol} \mathrm{mol}^{-1}$. For the anvil penetrations of 4 and 18 February listed in Table $2 \mathrm{a}$, average LNOx volume mixing ratios $\left(\chi_{\text {LNOx }}\right)$ were determined by subtraction of the mean $\mathrm{BL}-\mathrm{NO}_{\mathrm{x}}$ contribution $\left(0.11 \mathrm{nmol} \mathrm{mol}^{-1}\right)$ from the mean anvil- $\mathrm{NO}_{\mathrm{x}}$ values. The mean values for anvil- $\mathrm{NO}_{\mathrm{x}}$ range between 0.2 $0.8 \mathrm{nmol} \mathrm{mol}^{-1}$ in the subtropical thunderstorm of $18 \mathrm{Febru}-$ ary and between $0.7-1.2 \mathrm{nmol} \mathrm{mol}^{-1}$ in the tropical thunderstorms of 4 February (Table 2a in HH07). As a result, $\chi_{\text {LNOx }}$ values in the range from 0.1 to $1.1 \mathrm{nmol} \mathrm{mol}^{-1}$ were obtained, as listed in Table 2a in the present paper.

Overall, the contribution of $\mathrm{BL}-\mathrm{NO}_{\mathrm{x}}$ to anvil- $\mathrm{NO}_{\mathrm{x}}$ in the selected thunderstorms of 4 February (anvil 1a, 5a, and 2b) and 18 February (only anvil penetrations I, III and V closest to the core considered here) was $\sim 10-20 \%$. This range 
a)

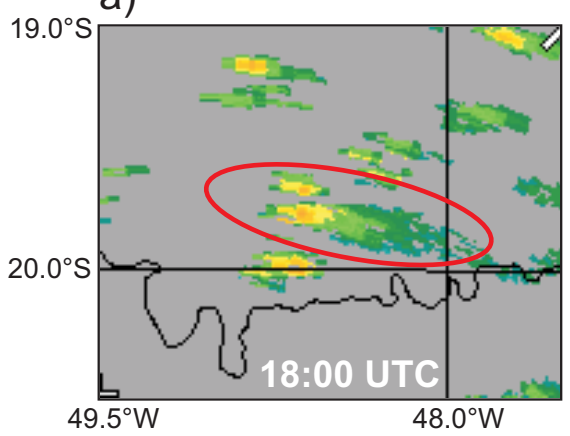

c)

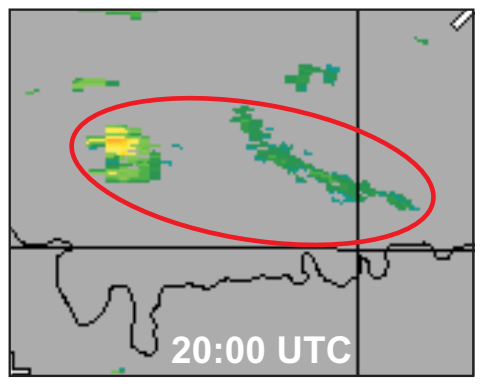

b)

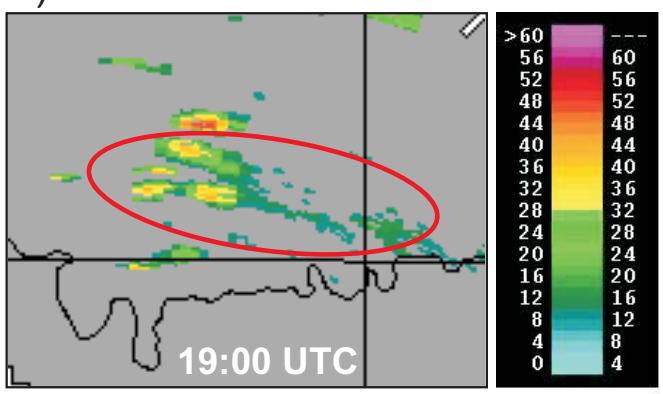

d)

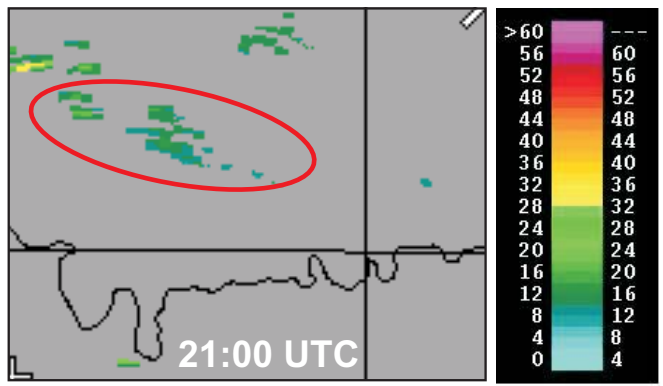

Fig. 8. Radar reflectivity as PPI scan (PPI_SURVEILLANCE operational product) in dBZ units measured at $0.0^{\circ}$ elevation by the Bauru radar $\left(22.4^{\circ} \mathrm{S}, 49.0^{\circ} \mathrm{W}\right)$ for the 18 February 2005 subtropical thunderstorm system (marked in red) at (a) 18:00 UTC, (b) 19:00 UTC, (c) 20:00 UTC and (d) 21:00 UTC.

is slightly lower than the average found in European thunderstorms with 25 to $40 \%$ (Huntrieser et al., 1998, 2002). In the investigated TROCCINOX thunderstorms, the contribution from LNOx clearly dominated the anvil- $\mathrm{NO}_{\mathrm{x}}$ budget with $\sim 80-90 \%$. This contribution is higher than observed during the TRACE-A experiment at the end of the dry (burning) season, where only $30-40 \%$ of anvil- $\mathrm{NO}_{\mathrm{x}}$ was attributed to LNOx (Pickering et al., 1996).

\subsection{Estimate of the horizontal LNOx mass flux}

Cloud-model simulations indicate that most LNOx produced in a thunderstorm is transported into the anvil (Skamarock et al., 2003). If the total LNOx mass in the anvil region (dependent on the LNOx mixing ratio and the volume covered by this LNOx) and the total number of flashes in the thunderstorm that contributed to this LNOx were known, the LNOx production rate per flash could be estimated, assuming a constant LNOx production per flash. Up to now, however, no method exists which can determine the required parameters exactly. Model approaches have e.g. estimated the horizontal $\mathrm{NO}_{\mathrm{x}}$ flux out of the anvil through a vertical control surface (Skamarock et al., 2003; Barthe et al., 2007). A combination of in situ aircraft observations and cloud-model simulations was used to separate the outflow flux into a LNOx flux and an environmental $\mathrm{NO}_{\mathrm{x}}$ flux. This approach was originally introduced by Chameides et al. (1987) for airborne measurements in thunderstorms during GTE/CITE and has also been applied by us for measurements in LINOX and EULINOX thunderstorms (Huntrieser et al., 1998, 2002). Alternatively, the NO content in the thunderstorm is estimated from the product of airborne in situ measurements of $\mathrm{NO}$ at certain levels in the anvil and the estimated volume of the appropriate cloud segments (Ridley et al., 2004). The total volume is derived from the sum of the vertically staggered flight segments. The two methods are described in more detail in SH07.

The TROCCINOX thunderstorm penetrations listed in Table 2 a provide only snapshots of the conditions at a certain level of the cloud at a certain time. It is not known how representative these anvil penetrations are for the average anvil conditions (see also discussion in Sect. 3.2). These are, however, the only measurements that are available. Time series of trace gas measurements $\left(\mathrm{NO}_{\mathrm{x}}, \mathrm{CO}\right.$, and $\left.\mathrm{O}_{3}\right)$ during the penetrations listed in Table 2a have already been presented and discussed in HH07. On the 18 February flight, the anvil outflow from the selected thunderstorm system was successfully penetrated 6 times (Fig. $4 \mathrm{~b}$ ). In addition to the mentioned trace gases, $\mathrm{NO}_{\mathrm{y}}$ was measured and mixing ratios during the 6 penetrations are shown together with the vertical velocity (absolute values) in Fig. 11. The $1 \mathrm{~s}$ absolute 


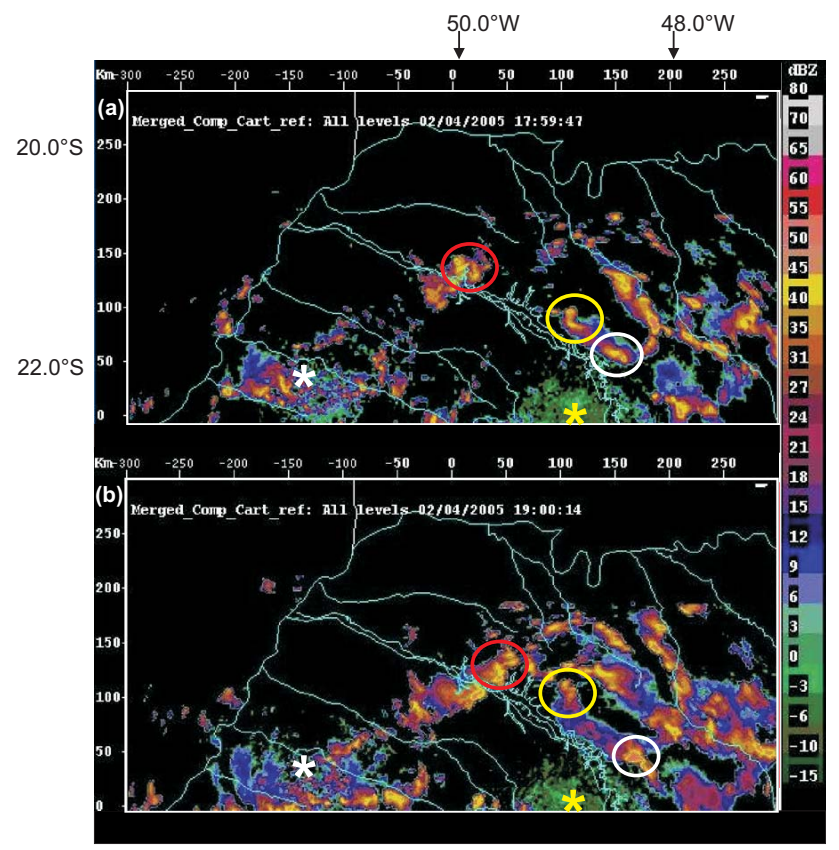

Fig. 9. Vertical maximum of the radar reflectivity (max CAPPI frame, unit dBZ). Composite from the Bauru $\left(22.4^{\circ} \mathrm{S}, 49.0^{\circ} \mathrm{W}\right)$ and Presidente Prudente $\left(22.1^{\circ} \mathrm{S}, 51.4^{\circ} \mathrm{W}\right)$ radars for the 4 February 2005 thunderstorms at (a) 17:59:47 UTC, and (b) 19:00:14 UTC. Selected thunderstorms are marked (tropical: yellow circle anvil 1a, white circle anvil $5 \mathrm{a}$ and red circle anvil $2 \mathrm{~b}$ ). The change in location of each of these circles between (a) and (b) indicates the storm motion, which can be compared with the storm motion indicated by arrows in Fig. 4a. The Bauru and Presidente Prudente radar sites are indicated with a yellow and white *, respectively. The left and upper axes give the distance in $\mathrm{km}$, and the latitude and longitude are indicated in (a). (TITAN Software, installed at IPMet in collaboration with NCAR.)

velocity values mainly varied between 0.1 and $1.0 \mathrm{~m} \mathrm{~s}^{-1}$ indicating that the measurements were carried out outside the core region of the thunderstorm cell, where far higher vertical velocities are to be expected. The highest $\mathrm{NO}_{\mathrm{y}}$ mixing ratios were measured during the anvil penetrations with the strongest vertical velocities, which is closer to the core region $(\sim 10-30 \mathrm{~km})$ where most lightning occurs (penetration I, III and V). The closest penetration to the maximum anvil outflow level was penetration III, where the mean updraft velocity $\left(0.8 \mathrm{~m} \mathrm{~s}^{-1}\right)$ was distinctly higher than the mean downdraft velocity $\left(0.2 \mathrm{~m} \mathrm{~s}^{-1}\right)$, and the highest mean $\mathrm{NO}_{\mathrm{y}}$ mixing ratio $\left(1.1 \mathrm{nmol} \mathrm{mol}^{-1}\right)$ was measured. About $30 \mathrm{~km}$ farther downwind (penetration II, IV, VI), the measurements indicate that a large part of the outflow already mixed with the ambient air (similar mean updraft and downdraft velocities).

Moreover, on 4 February the selected thunderstorms were penetrated only once, but rather close to the core. Hence, too few repeated anvil penetrations and limited radar reflectivity data are available to apply the method introduced by

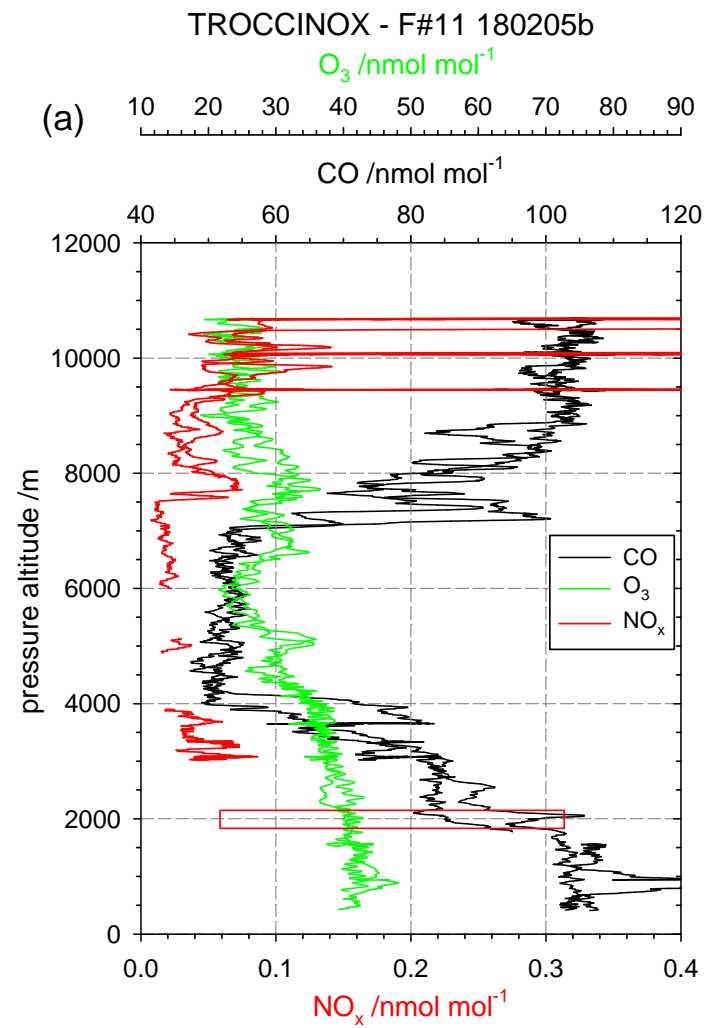

(b)

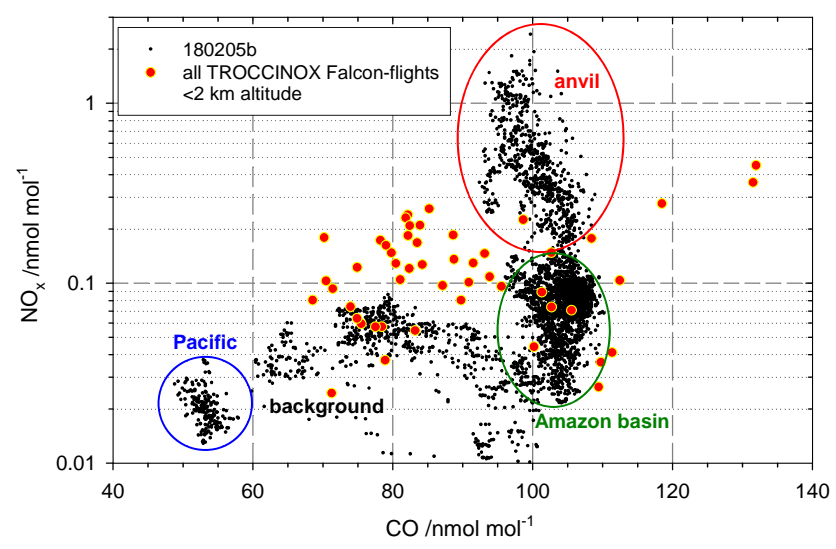

Fig. 10. (a) Vertical profiles for $\mathrm{CO}, \mathrm{O}_{3}$, and $\mathrm{NO}_{\mathrm{x}}$ mixing ratios from the Falcon flight on 18 February 2005. The red box at $2 \mathrm{~km}$ altitude indicates the top of the mixed layer. (b) Correlation plot for $\mathrm{NO}_{\mathrm{x}}$ and $\mathrm{CO}$ for the same flight (black dots), and superimposed data from all TROCCINOX Falcon-flights in the boundary layer $(<2 \mathrm{~km})$ (red-yellow dots).

Ridley et al. (2004). We therefore use a modified version of the method introduced by Chameides et al. (1987) and assume that the measurements during each anvil penetration (snapshots) are representative average anvil conditions. We consider the horizontal mass flux of LNOx through a vertical control surface. The vertical surface dimensions can 
be estimated from the combination of e.g. airborne measurements and FLEXPART simulations as explained before in Sect. 4.2 and as indicated in Fig. 3. Repeated penetrations of the 18 February thunderstorm system indicated that $\Delta z$ was $>1.3 \mathrm{~km}(10.7-9.4 \mathrm{~km}$, Table $2 \mathrm{a})$. The entire vertical extent of the anvil outflow can be most clearly seen in vertical profiles of the $\mathrm{CO}$ mixing ratio measured by the highflying Geophysica (personal communication, P. Mazzinghi, INOA/CNR). On 18 February the most distinct enhancement in the CO mixing ratio was observed between $\sim 9-12 \mathrm{~km}$ altitudes and $\Delta z$ was set to $\sim 3 \mathrm{~km}$ (see Table $2 \mathrm{a}$ ). On 4 February the enhancement in $\mathrm{CO}$ was less clear owing to elevated background mixing ratios: enhanced mixing ratios were mainly observed between $\sim 10-14 \mathrm{~km}$ altitudes and $\Delta z$ was set to $\sim 4 \mathrm{~km}$ (see Table $2 \mathrm{a}$ ).

The horizontal LNOx mass flux $F_{\mathrm{LNOx}}$ (in nitrogen mass per time, $\mathrm{g} \mathrm{s}^{-1}$ ) was calculated for each thunderstorm penetration listed in Table $2 \mathrm{a}$ according to:

$F_{\mathrm{LNOx}}=\chi_{\mathrm{LNOx}} \cdot \frac{M_{N}}{M_{\mathrm{air}}} \cdot \rho_{a}\left(V_{a}-V_{s}\right) \cdot \Delta x \cdot \Delta z$

where $\chi_{\text {LNOx }}$ is the mean $\mathrm{NO}_{\mathrm{x}}$ volume mixing ratio produced by lightning $\left(\mathrm{mol} \mathrm{mol}^{-1}\right), M_{N}$ and $M_{\text {air }}$ are the molar masses of nitrogen $\left(14 \mathrm{~g} \mathrm{~mole}^{-1}\right)$ and air $\left(29 \mathrm{~g} \mathrm{~mole}^{-1}\right)$, respectively, $\rho_{a}$ is the air density $\left(\mathrm{g} \mathrm{m}^{-3}\right)$ calculated from measured temperature and pressure in the anvil, and $V_{a}-V_{s}$ is the difference between the wind vectors in the anvil outflow and at the steering level (see Table 2b). The last term $\Delta x \cdot \Delta z$ is the area $\left(\mathrm{m}^{2}\right)$ of the vertical cross-section perpendicular to the wind direction in the anvil outflow. In general, the wind at the steering level $(\sim 700 \mathrm{hPa})$ determines the mean motion of a thunderstorm cell (e.g. Keenan and Carbone, 1992), but this parameter is not available from the airborne measurements. Instead, horizontal LINET stroke distributions, as shown in Fig. 4, were plotted with a higher temporal resolution (10 min) and the storm motion $\left(V_{S}\right)$ was determined from the temporal stroke evolution. The parameters in Eq. 4, except $\Delta x$ (Sect. 4.2) and $\Delta z$, were calculated directly from Falcon measurements by averaging the measured data over the time period when the thundercloud was penetrated (between entry and exit of anvil), see Table $2 \mathrm{a}$.

$F_{\mathrm{LNOx}}$ values were calculated for the selected thunderstorms by insertion of the parameters listed in Table 2a into Eq. 4, which give nitrogen mass flux values between 48 and $178 \mathrm{~g} \mathrm{~s}^{-1}$ (Table 2a). The flux values for subtropical thunderstorms (only anvil I, II, and V considered) and tropical thunderstorms are within a similar range. The flux values in Table 2a can be divided by the molar mass for nitrogen and the area of the vertical cross-section $(\Delta x \cdot \Delta z)$ to estimate the flux in the unit mol m${ }^{-2} \mathrm{~s}^{-1}$. The range of these fluxes, 3.3$7.1 \times 10^{-8} \mathrm{~mol} \mathrm{~m}^{-2} \mathrm{~s}^{-1}$, is well comparable to nitrogen mass flux values simulated by Barth et al. (2007) who ran different cloud-scale models (range $2.7-13.0 \times 10^{-8} \mathrm{~mol} \mathrm{~m}^{-2} \mathrm{~s}^{-1}$ ) and to Barthe et al. (2007), who simulated $6 \times 10^{-8} \mathrm{~mol} \mathrm{~m}^{-2} \mathrm{~s}^{-1}$ on average in the anvil outflow of a STERAO storm.
TROCCINOX - F\#11 180205b

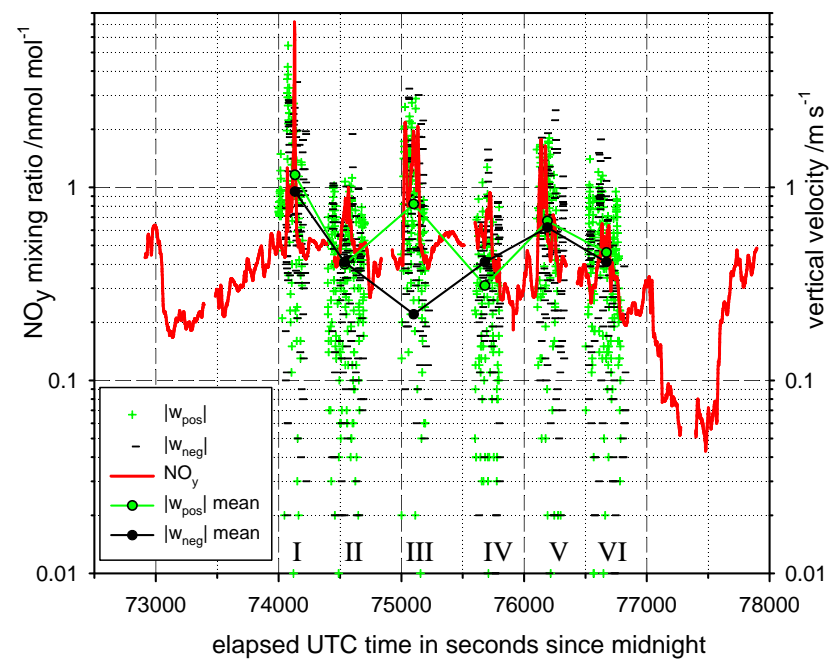

Fig. 11. Time series of $\mathrm{NO}_{\mathrm{y}}$ mixing ratio and absolute vertical velocity for the Falcon flight on 18 February 2005. The anvil penetrations are labelled I-VI.

The parameters listed in Table 2a have large uncertainties. The relative maximal error of the $F_{\mathrm{LNOx}}$ estimate was therefore calculated. The uncertainty for $\chi_{\mathrm{LNOx}}$ is given by the standard deviation (on average $\sim 50 \%$ of the mean value); for $V_{a}-V_{s}$ the standard deviations listed in Table $2 \mathrm{~b}$ indicate an uncertainty of up to $\sim 50 \%$; for $\Delta x$ the uncertainty was $\sim 5-10 \mathrm{~km}$ corresponding to $\sim 40 \%$; and for $\Delta z$ the vertical anvil extension on 4 February varied between $3.5-6 \mathrm{~km}$ and on 18 February between $2-4 \mathrm{~km}$ indicating an uncertainty up to $\sim 50 \%$. Summing up these uncertainties, the relative maximal error of the $F_{\text {LNOx }}$ estimate is $\sim 190 \%$.

\subsection{Estimate of the LNOx production rate per stroke and per year}

For the estimate of the LNOx production rate $P_{\mathrm{LNOx}}$ (nitrogen mass per stroke, in $\mathrm{g}$ stroke ${ }^{-1}$ ), the horizontal LNOx mass flux $F_{\text {LNOx }}\left(\mathrm{g} \mathrm{s}^{-1}\right)$ is divided by the LINET stroke rate $R_{\text {LINET }}\left(\right.$ strokes s $^{-1}$ ):

$P_{\text {LNOx }}=\frac{F_{\text {LNOx }}}{R_{\text {LINET }}}$

$P_{\text {LNOx }}$ estimates for the selected anvil penetrations resulted in values between 1.9 and $5.6 \mathrm{~kg} \mathrm{stroke}^{-1}$, see Table $2 \mathrm{a}$. Unfortunately, the dataset in Table $2 \mathrm{a}$ is very sparse. Nevertheless, mean $P_{\mathrm{LNOx}}$ values for three tropical and one subtropical thunderstorms (only anvil penetrations I, III and V considered) are estimated to 2.4 and $4.5 \mathrm{~kg} \mathrm{stroke}^{-1}$, respectively, which corresponds to $4.8 \times 10^{25}$ and $9.0 \times 10^{25}$ molecules NO stroke ${ }^{-1}$. These results suggest that a subtropical thunderstorm may produce more LNOx per LINET stroke than a tropical thunderstorm (factor $\sim 2$ ). Possible reasons for this difference will be discussed in Sects. 5 and 6. 


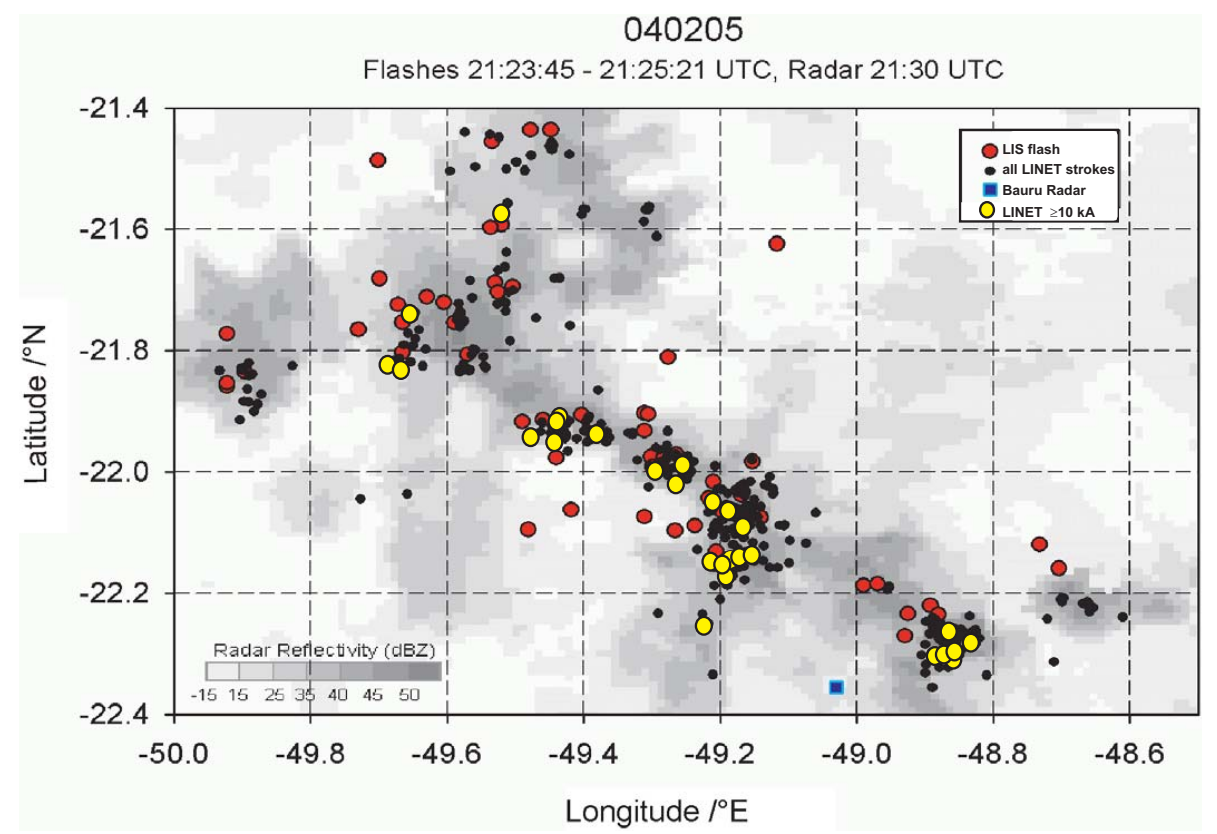

Fig. 12. Vertical maximum of the radar reflectivity (max CAPPI frame, unit dBZ) on 4 February 2005 at 21:30 UTC measured by the Bauru $\left(22.4^{\circ} \mathrm{S}, 49.0^{\circ} \mathrm{W}\right)$ and Presidente Prudente $\left(22.1^{\circ} \mathrm{S}, 51.4^{\circ} \mathrm{W}\right)$ radars. Superimposed are the horizontal distributions of LIS flashes (in red) and LINET strokes (black and yellow) for the time period 21:23:45 UTC-21:25:21 UTC.

For comparison with other published results, the $P_{\mathrm{LNOx}}$ estimates per LINET stroke were scaled to $P_{\text {LNOx }}$ estimates per LIS flash. During the TROCCINOX field period from 21 January to 27 February 2005, only one overpass of 4 February at 21:23:45-21:25:21 UTC provided a sufficient large set of coincident LINET and LIS measurements. On this day, lightning activity in the LINET centre area $\left(21.5-22.5^{\circ} \mathrm{S}\right.$ and $48.5-49.5^{\circ} \mathrm{W}$ ) and close-by (covering totally $20.0-23.0^{\circ} \mathrm{S}$ and $48.5-50.5^{\circ} \mathrm{W}$ ) was suitable for comparison. Overall 82 LIS flashes and 481 LINET strokes were registered in the studied area during the $\sim 90 \mathrm{~s}$ measurement. LINET strokes with peak currents down to at least $4 \mathrm{kA}$ (absolute value) were sensed by LIS. For the selected time period, Fig. 12 shows the horizontal distributions of all available LINET strokes (black dots) and LIS flashes (red dots) for the area where most lightning occurred $\left(21.4-22.4^{\circ} \mathrm{S}\right.$ and $48.5-50.0^{\circ} \mathrm{W}$ ) together with radar reflectivity (grey). For the $P_{\text {LNOx }}$ estimate, only stronger LINET strokes with peak currents $\geq 10 \mathrm{kA}$ are considered (in total 41 strokes, yellow dots) as mentioned before in Sect. 4.1. The LIS detection efficiency at night (0.93) was taken into account (21:2321:25 UTC $=19: 23-19: 25$ Brazilian Summer Time). This implies a LINET/LIS ratio of about $(41 / 82) \times 0.93=0.5$, considering only LINET strokes with peak currents $\geq 10 \mathrm{kA}$.

By means of this ratio, the mean values for $P_{\text {LNOx }}$ per LIS flash for tropical and subtropical thunderstorms (only anvil penetrations I, III, and V considered) are 1.2 and 2.2 (range $0.9-2.8) \mathrm{kg}$, respectively, corresponding to 2.4 and 4.5 (range 1.9-5.6) $\times 10^{25}$ molecules NO. These estimates for TROC-
CINOX are well within the range of more recent estimates. From a review of previous investigations, $\mathrm{SH} 07$ derive a bestestimate of 3.5 (range 0.5-10) kg of nitrogen per flash.

The estimates for $P_{\text {LNOx }}$ per LIS flash were multiplied with the number of LIS flashes occurring globally, 44 flashes s $^{-1}$. If the selected tropical and subtropical TROCCINOX thunderstorms were representative for the globe, the implied mean annual global LNOx production rate $G_{\text {LNOx }}$ would be $\sim 1.6$ and $3.1 \mathrm{Tg} \mathrm{a}^{-1}$, respectively (factor $\sim 2$ difference). These values are close to previous best estimates for mid-latitude thunderstorms, see introduction. The individual estimates for the single thunderstorm penetrations listed in Table $2 \mathrm{a}$, however, range from 1.3 to $3.9 \mathrm{Tg} \mathrm{a}^{-1}$, indicating a wide range of values and large uncertainties depending on where (horizontally and vertically) the anvil was penetrated.

Finally, the relative maximal errors of the $P_{\mathrm{LNOx}}$ and $G_{\text {LNOx }}$ estimates (Table 2a) were calculated. The uncertainty for $R_{\text {LINET }}$ was estimated from the standard deviations of the time series of the LINET stroke rates (Fig. 5). The standard deviations varied between $50-90 \%$ of the mean values. From the estimates for $F_{\mathrm{LNOx}} \sim 190 \%$ and $R_{\mathrm{LINET}} \sim 90 \%$, the relative maximal error of the $P_{\mathrm{LNOx}}$ estimate for LINET strokes was $\sim 280 \%$. For the $P_{\text {LNOx }}$ estimate for LIS flashes, it was assumed that the uncertainty in the conversion of LINET strokes ( $\geq 10 \mathrm{kA}$ ) to LIS flashes was $\sim 30 \%$ (depending on which LIS detection efficiency was used: day or night). This gives a relative maximal error of $\sim 310 \%$. For the $G_{\text {LNOx }}$ estimate, the uncertainty in the global LIS flash rate was given with $\sim 10 \%$, which gives a final relative maximal error of 
(a)

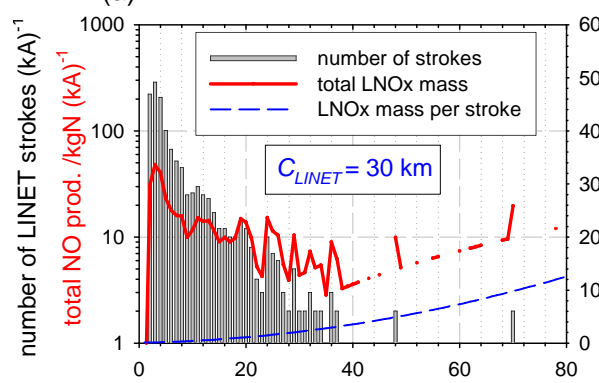

(b) (d)

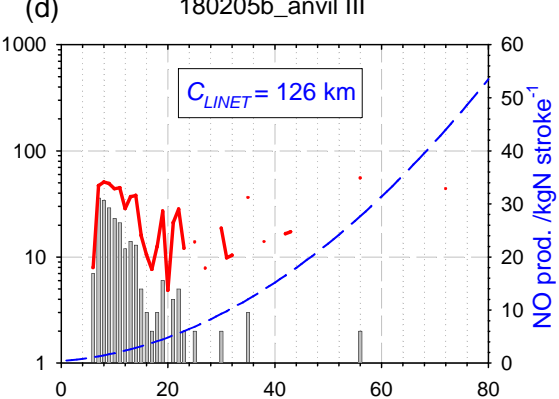

(e) 040205_LINET centre (00-24 UTC)

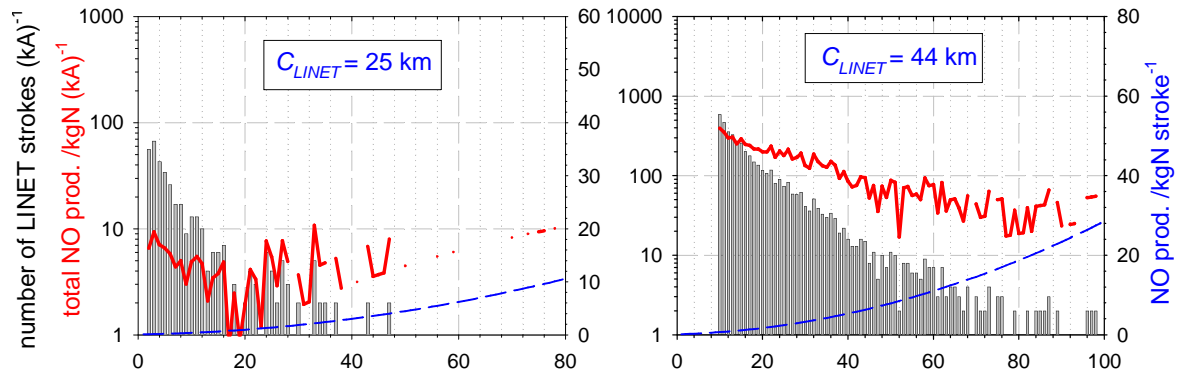

(c)

040205_anvil 2b

(f) 180205b_anvil I-VI (14-21 UTC)
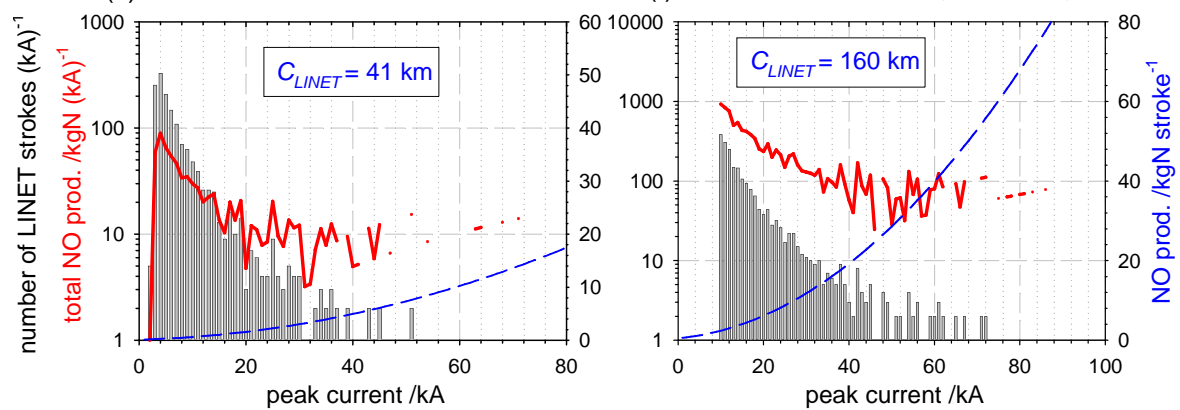

Fig. 13. Frequency distribution of LINET strokes (vertical grey bars) as a function of peak current for the selected tropical and subtropical thunderstorm systems on 4 and 18 February 2005, respectively (see Table 3). Superimposed is the laboratory result by Wang et al. (1998) modified for LINET strokes (blue dashed line) according to Table $3\left(C_{\text {LINET }}\right)$ and the estimated total amount of LNOx mass produced per 1 kA LINET stroke interval for the selected thunderstorm systems (red line), see mass estimates in Table 3.

$\sim 320 \%$. Given this relative maximum error, the final range for the $G_{\text {LNOx }}$ values listed in Table $2 \mathrm{a}$ is between 0.4 and $12 \mathrm{Tg} \mathrm{a}^{-1}$. This range is comparable to other ranges given for $G_{\text {LNOx }}$ in previous publications (see Sect. 1 and SH07).

\section{Possible explanations for different LNOx production rates in tropical, subtropical and mid-latitude thun- derstorms}

The results in the previous section lead us to hypothesise that tropical thunderstorms over Brazil may produce less LNOx per stroke than subtropical thunderstorms. In this section we investigate whether these differences in the LNOx production rate may be related to differences in the stroke peak currents (Sect. 5.1), stroke lengths (Sect. 5.1) or stroke release heights
(Sect. 5.2) (relationships investigated by Wang et al., 1998, in the laboratory). Furthermore, mean stroke peak currents observed by LINET are compared for several tropical and mid-latitude thunderstorms and for one subtropical thunderstorm (Sects. 5.3-5.4).

5.1 LNOx production rate as a function of stroke peak current

In this subsection we combine the result of laboratory measurements by Wang et al. (1998) with our field measurements to determine the LNOx production rate as a function of peak current. Wang et al. (1998) determined the NO production rate per unit laboratory spark, whereas our analysis provides the NO production rate per LINET stroke in the field. We assume that both follow the same dependency on peak current 
Table 3. Lightning-produced NO mass per LINET stroke $P_{\mathrm{LNOx}}$, for tropical and subtropical thunderstorms considering different stroke peak currents.

\begin{tabular}{|c|c|c|c|c|c|c|c|c|c|c|c|}
\hline $\begin{array}{l}\text { Flight and Anvil } \\
\text { Penetration/ } \\
\text { tropical (t) or } \\
\text { subtropical (s) }\end{array}$ & $\begin{array}{l}\text { Registered/ } \\
\text { Considered } \\
\text { Stroke Peak } \\
\text { Currents }^{1} \text {, } \\
\text { kA }\end{array}$ & $\begin{array}{l}\text { Duration, } \\
\text { of Stroke } \\
\text { Activity }{ }^{2} \text {, } \\
\text { min }\end{array}$ & $\begin{array}{l}\text { Number } \\
\text { of LINET } \\
\text { Strokes }^{2}\end{array}$ & $\begin{array}{l}R_{\text {LINET, }}, \\
\text { (LINET } \\
\text { strokes) } \\
\mathrm{s}^{-1}\end{array}$ & $\begin{array}{l}\mathrm{F}(\mathrm{LNOx})^{3} \\
\mathrm{~g}(\mathrm{~N}) \mathrm{s}^{-1}\end{array}$ & $\begin{array}{l}\text { Integral }^{4}, \\
\text { strokes s } \\
\times 10^{-3} \mathrm{~g} \mathrm{~m}^{-1} \\
\text { laboratory } \\
\text { spark }\end{array}$ & $\begin{array}{l}C_{\text {LINET }^{5}, \mathrm{~m}} \\
\text { laboratory } \\
\text { spark } \\
\text { stroke }^{-1}\end{array}$ & $\begin{array}{l}\text { Total } \\
\text { Nitrogen } \\
\text { Mass } \\
\text { Produced }^{6}, \\
\times 10^{3} \mathrm{~g}\end{array}$ & $\begin{array}{l}P_{\text {LNOx }}{ }^{7}, \\
\mathrm{~g}(\mathrm{~N}) \\
(\mathrm{LINET} \\
{\text { stroke })^{-1}}^{-1}\end{array}$ & $\begin{array}{l}S, \mathrm{~g}(\mathrm{~N}) \\
(\mathrm{kA})^{-1} \\
\left(\times 10^{3}\right. \\
\text { laboratory } \\
\text { spark })^{-1}\end{array}$ & $\begin{array}{l}\text { Pressure, } \\
\mathrm{hPa}\end{array}$ \\
\hline 040205_1a (t) & $\geq 2$ & 85 & 1287 & 0.252 & 120 & 4.04 & 29732 & 613 & 476 & 2.0 & 240 \\
\hline 040205_5a (t) & $\geq 2$ & 40 & 400 & 0.167 & 113 & 4.52 & 24946 & 271 & 677 & 2.3 & 235 \\
\hline $040205 \_2 b(t)$ & $\geq 2$ & 85 & 1492 & 0.293 & 178 & 4.31 & 41239 & 906 & 607 & 1.8 & 260 \\
\hline 180205b_III (s) & $\geq 6$ & 85 & 236 & 0.046 & 143 & 1.13 & 126393 & 731 & 3097 & 1.9 & 260 \\
\hline 040205_1a (t) & $\geq 10$ & 85 & 278 & 0.055 & 120 & 2.71 & 44390 & 613 & 2205 & 2.8 & 240 \\
\hline $040205 \_5 a(t)$ & $\geq 10$ & 40 & 130 & 0.054 & 113 & 3.72 & 30285 & 271 & 2082 & 2.6 & 235 \\
\hline $040205 \_2 b(t)$ & $\geq 10$ & 85 & 311 & 0.061 & 178 & 2.48 & 71516 & 906 & 2914 & 2.1 & 260 \\
\hline 180205b_III (s) & $\geq 10$ & 85 & 130 & 0.025 & 143 & 0.89 & 160324 & 731 & 5623 & 2.1 & 260 \\
\hline
\end{tabular}

${ }^{1}$ On 4 February 2005 strokes with peak currents down to $2 \mathrm{kA}$ were registered (mainly within the LINET centre). On 18 February 2005 only strokes with peak currents $\geq 6 \mathrm{kA}$ were registered (mainly along the LINET periphery). Thus, on 18 February the detection efficiency for low peak currents was lower than on 4 February and the stroke characteristics are not comparable (upper half of the table). For a more equivalent comparison between the 4 and 18 February only strokes with peak currents $\geq 10 \mathrm{kA}$ were considered (lower half of the table).

2 On 4 February 2005 the registered/considered strokes until penetration were active from 16:55 to 18:20 UTC within anvil 1a (85 min.), from 17:55 to 19:20 UTC within anvil $2 \mathrm{~b}(85 \mathrm{~min})$ and from 18:05 to 18:45 UTC within anvil 5a (40 min) On 18 February 2005 the registered/considered strokes until storm decay were active between 19:30 and 20:55 UTC (85 min).

3 The horizontal LNOx mass flux out of the anvil (see Eq. 4). Values from Table 2a are given.

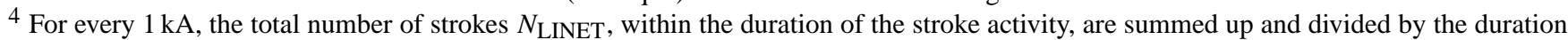
of the stroke activity which gives $R_{\text {LINET }}(I)$ (see Eq. 9). $R_{\text {LINET }}(I)$ is then multiplied with the Wang et al. 1998 laboratory relationship $M_{\mathrm{NOlab}}(I)$ (see below 6 and Eq. 7) and summed up over all $1 \mathrm{kA}$ intervals (part of Eq. 8 and Eq. 9): $\int_{I=1}^{\infty} R_{\mathrm{LINET}}(I) \times M_{\mathrm{NO}_{\text {lab }}}(I) d I$ where $R_{\text {LiNET }}(I)=\frac{1}{t} \int_{t=0}^{t} N_{\text {LINET }}(I, t) d t$

5 Conversion of the Wang et al. 1998 laboratory relationship to LINET strokes (see Eq. 8):

$C_{\mathrm{LINET}}=F_{\mathrm{LNOx}} / \int_{I=1}^{\infty} R_{\mathrm{LINET}}(I) \times M_{\mathrm{NO}_{\mathrm{lab}}}(I) d I$

6 The total nitrogen mass produced by the thunderstorm within the duration of the stroke activity. For every 1 kA interval and the duration of the stroke activity, $M_{\mathrm{NO}} l \mathrm{lab}(I)$ (Eq. 7) modified for LINET (Eq. 10) is multiplied with the total number of strokes $N_{\text {LINET }}(I)$ and summed up over all peak currents.

7 Nitrogen mass produced per considered stroke.

as given by Wang et al. (1998). Hence, both differ only by a constant factor, which has the dimension of laboratory spark length per LINET stroke. This factor will be determined below.

The relationship between the peak current and NO produced per spark as found by Wang et al. (1998) from measurements in the laboratory (at $1.01 \times 10^{5} \mathrm{~Pa}$ ) is given by:

$n_{\mathrm{NO}_{\mathrm{lab}}}(I)=a+b \times I+c \times I^{2}$

where $n_{\text {NOlab }}(I)$ is the NO production normalised to $1 \mathrm{~m}$

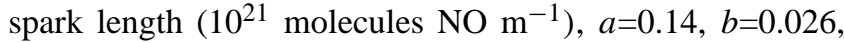
and $c=0.0025$ and $I$ is the peak current of the spark $(\mathrm{kA})$. The number of NO molecules can be converted to the mass of nitrogen according to:

$M_{\mathrm{NO}_{\mathrm{lab}}}(I)=M_{W} \times n_{\mathrm{NO}_{\mathrm{lab}}}(I)$

where $M_{\mathrm{NOlab}}(I)$ is the nitrogen production per to $1 \mathrm{~m}$ spark length $\left(10^{-3} \mathrm{~g} \mathrm{~m}^{-1}\right)$ and $M_{W}$ is a constant (molecular weight of $\mathrm{N}$, unit $\mathrm{g}$ molecule ${ }^{-1}$ ). According to Eq. (7) a laboratory spark with $10 \mathrm{kA}$ would produce $0.015 \mathrm{~g}$ nitrogen $\mathrm{m}^{-1}$.

Furthermore, Eq. (7) was multiplied with a constant factor $C_{\text {LINET }}$ (m laboratory spark per LINET stroke) to convert the production per laboratory sparks and metre to the total number of LINET strokes. Here we assume that all LINET strokes in one specific anvil have the same length, independent of peak current and flash component, since no further information is available from our dataset. The factor $C_{\text {LINET }}$ was estimated from Eq. (8). Values from Table 3 for anvil 1a (lower half of table, here only strokes $\geq 10 \mathrm{kA}$ considered) were inserted in Eq. (8); the mean LNOx mass flux, $F_{\text {LNOx }},\left(120 \mathrm{~g} \mathrm{~s}^{-1}\right)$, and the LINET stroke rate (strokes s ${ }^{-1}$ ), $R_{\text {LINET }}(I)$, for a given peak current $I$ :

$$
F_{\mathrm{LNOx}}=C_{\mathrm{LINET}} \int_{I=10}^{\infty} R_{\mathrm{LINET}}(I) \times M_{\mathrm{NO}_{\mathrm{lab}}}(I) d I
$$


where $R_{\text {LINET }}(I)$ was estimated from Eq. (9):

$$
R_{\text {LINET }}(I)=\frac{1}{t} \int_{t=0}^{t} N_{\text {LINET }}(I, t) d t
$$

and $N_{\text {LINET }}(I, t)$ is the number of LINET strokes for a given peak current and time.

The value of $R_{\text {LINET }}$ in Eq. (9), integrated over all peak currents (here $\geq 10 \mathrm{kA}$ ), is 0.055 strokes $\mathrm{s}^{-1}$ (Table 3 lower half, anvil 1a). The total integral in Eq. (8) (peak currents from anvil 1a inserted) is estimated to $2.71 \times 10^{-3}$ strokes s ${ }^{-1} \mathrm{~g} \mathrm{~m}^{-1}$ laboratory spark. The corresponding LINET factor, $C_{\text {LINET }}$, was estimated to $44.4 \times 10^{3}$ $\left(=120 /\left(2.71 \times 10^{-3}\right)\right) \mathrm{m}$ laboratory spark stroke ${ }^{-1}$ (see Table 3). We expect a LINET stroke in the atmosphere to be shorter than this calculated length $(44 \mathrm{~km})$, but probably broader than a laboratory spark. One metre LINET stroke is therefore probably more efficient in producing LNOx than a laboratory spark.

Applied to LINET strokes, Eq. (7) changes to:

$M_{\mathrm{NO}_{\text {linet }}}(I)=C_{\text {LINET }} \times M_{\mathrm{NO}_{\text {lab }}}(I)$

where $M_{\text {NOlinet }}(I)$ is the nitrogen mass production per LINET stroke $\left(\mathrm{g}\right.$ stroke $\left.{ }^{-1}\right)$. A LINET stroke with a peak current of $10 \mathrm{kA}$ (anvil 1a) would produce $0.7 \mathrm{~kg}$ nitrogen according to Eq. (10). This value is rather large because peak currents $<10 \mathrm{kA}$ were neglected (Table 3 , lower half) and the total LNOx mass was distributed only over strokes $\geq 10 \mathrm{kA}$ in Eq. (8).

The same calculations were performed for other selected thunderstorm penetrations of 4 and 18 February 2005, as shown in Figs. 13a-d and as listed in Table 3. In Table 3 every thunderstorm penetration is listed twice. For the first calculation (upper half in the table) all registered strokes were considered (peak currents down to 2 and $6 \mathrm{kA}$, depending on the detection efficiency in that area). For a comparison between the 4 and 18 February selected penetrations, however, only strokes with peak currents $\geq 10 \mathrm{kA}$ were considered, as listed in the lower half of the table.

In Fig. 13a-d the frequency distributions of LINET strokes (grey bars) per $1 \mathrm{kA}$ peak current interval are shown for the selected thunderstorms of 4 and 18 February 2005. The stroke frequency rapidly decreases with increasing peak current. Superimposed are the laboratory results by Wang et al. (1998) concerning the NO dependency on peak current modified for LINET strokes (blue dashed line) according to Table 3 (different $C_{\text {LINET }}$ values considered), and in addition the estimated total amount of nitrogen mass produced per $1 \mathrm{kA}$ LINET stroke interval for the selected thunderstorm systems (red line). The total mass estimates are listed in Table 3 .

In Fig. 13e-f the same type of calculations were performed for datasets with a larger number of LINET strokes to point out more clearly the differences between the stroke peak current frequency distributions of 4 and 18 February. All strokes $(\geq 10 \mathrm{kA})$ in the LINET centre area on 4 February between 00:00 and 24:00 UTC were considered in Fig. 13e. In Fig. 13f the same calculations were performed for the selected thunderstorm system of 18 February for all strokes ( $\geq 10 \mathrm{kA}$ ) between 14:00 UTC and 21:00 UTC (see Fig. 4b). The integral over all peak currents gives a total nitrogen mass of $8.8 \times 10^{3} \mathrm{~kg}$ produced by 4359 tropical strokes on 4 February (Fig. 13e), and a larger value of $11.2 \times 10^{3} \mathrm{~kg}$ produced by 2034 subtropical strokes on 18 February (Fig. 13f). This example also suggests that a subtropical stroke may produce a larger amount of nitrogen mass than a tropical stroke (here by a factor 2.7), mainly owing to differences in the stroke length (160 and $44 \mathrm{~km}$, respectively). The higher production rate of LNOx by subtropical strokes was not caused by the stroke peak currents, since this frequency distribution was shifted to lower peak currents on 18 February (mean 31 kA, calculated from data in Fig. 2) compared with 4 February (mean $35 \mathrm{kA}$ ), as indicated in Fig. 13e-f.

From the stroke frequency distributions of 4 February it was estimated that strokes with peak currents $\geq 5 \mathrm{kA}$ (only $30 \%$ of all strokes) produce the bulk amount $(70 \%)$ of the total nitrogen mass. This result indicates that the numerous weak strokes with peak currents $<5 \mathrm{kA}$ are less important for the LNOx production. In Fig. 14 the same stroke frequency distribution separated, however, into IC and CG strokes, indicates that these weak strokes are mainly IC strokes. Furthermore, Fig. 13a-b indicates that there was a large fraction of these strokes with low peak currents in anvil 1a compared with anvil 5a. Yet, the high stroke rate in anvil 1a $\left(0.252 \mathrm{~s}^{-1}\right)$ produces a similar mean LNOx mass flux, $F_{\mathrm{LNOx}}$, value as in anvil 5a with a much lower stroke rate $\left(0.167 \mathrm{~s}^{-1}\right)$ (Table 3, upper half). (The calculations for $F_{\mathrm{LNOx}}$ are based on similar penetration levels: 10.6 and $10.7 \mathrm{~km}$.) Furthermore, the calculated stroke length was slightly shorter in anvil 5a $(\sim 25 \mathrm{~km})$ compared with anvil $1 \mathrm{a}(\sim 30 \mathrm{~km})$, and the IC stroke release height (Table 4a) was slightly higher in anvil 5 a $(11.6 \mathrm{~km})$ compared with anvil $1 \mathrm{a}(10.0 \mathrm{~km})$. This result indicates that the lower stroke rate, shorter stroke length and higher stroke release height (see Sect. 5.2) in anvil 5a cannot explain the similar $F_{\mathrm{LNOx}}$ values determined for anvil 1a and 5a. Only if the higher stroke peak currents in anvil 5a (mean $12 \mathrm{kA}$, Table 4a) compared with anvil 1a (mean $8 \mathrm{kA}$ ) are considered, these may give an explanation in this case.

\subsection{LNOx production rate as a function of atmospheric pressure}

A further explanation for the different LNOx production rates of tropical and subtropical strokes in the selected Brazilian thunderstorms may be related to the release height of the strokes. Laboratory measurements by Wang et al. (1998) indicate that the LNOx production rate increases with increasing atmospheric pressure:

$n_{\mathrm{NO}_{\text {lab }}}(p)=a+b \times p$ 
Table 4a. LINET statistics of positive and negative CG and IC stroke fractions (here VLF pulses) and mean peak currents estimated for strokes with peak currents $\geq 1 \mathrm{kA}$.

\begin{tabular}{|c|c|c|c|c|c|c|c|c|c|c|c|c|}
\hline Date & Type of Thunderstorms/ Area ${ }^{1,2}$ & $\begin{array}{l}\text { Number } \\
\text { of } \\
\text { Strokes }^{3}\end{array}$ & $\begin{array}{l}\text { Mean Peak } \\
\text { Current, } \\
\text { kA }\end{array}$ & $\begin{array}{l}\text { CG } \\
\text { Strokes } \\
\text { (Fraction), } \\
\%\end{array}$ & $\begin{array}{l}\text { IC } \\
\text { Strokes } \\
\text { (Fraction), } \\
\%\end{array}$ & $\begin{array}{l}\text { Height } \\
\text { IC } \\
\text { Strokes, } \\
\text { km }\end{array}$ & $\begin{array}{l}\text { Ratio } \\
\text { Positive/ } \\
\text { Negative } \\
\text { Strokes }\end{array}$ & $\begin{array}{l}\text { Mean Peak } \\
\text { Current } \\
\text { (Fraction) } \\
\text { for CG-, } \\
\text { kA }(\%)\end{array}$ & $\begin{array}{l}\text { Mean Peak } \\
\text { Current } \\
\text { (Fraction) } \\
\text { for CG+, } \\
\text { kA }(\%)\end{array}$ & $\begin{array}{l}\text { Mean Peak } \\
\text { Current } \\
\text { (Fraction) } \\
\text { for IC-, } \\
\text { kA }(\%)\end{array}$ & $\begin{array}{l}\text { Mean Peak } \\
\text { Current } \\
\text { (Fraction) } \\
\text { for IC+, } \\
\text { kA }(\%)\end{array}$ & $\begin{array}{l}\text { Peak } \\
\text { Current } \\
\geq 10 \mathrm{kA} \\
\text { (Fraction), } \\
\%\end{array}$ \\
\hline & Tropical (Brazil) & & & & & & & & & & & \\
\hline 230105 & LINET centre & 11324 & 6 & $<44$ & $\geq 56$ & $10.3 \pm 2.9$ & 1.0 & $-9(23)$ & $+5(21)$ & $-5(28)$ & $+4(28)$ & 10 \\
\hline 240105 & LINET centre & 419 & 6 & 37 & 63 & $10.5 \pm 3.3$ & 1.1 & $-11(21)$ & $+5(16)$ & $-5(26)$ & $+4(37)$ & 11 \\
\hline 250105 & LINET centre & 848 & 7 & 47 & 53 & $9.6 \pm 2.8$ & 1.6 & $-11(21)$ & $+5(26)$ & $-8(17)$ & $+5(36)$ & 15 \\
\hline 040205 & LINET centre & 36234 & 6 & 43 & 57 & $9.7 \pm 3.1$ & 1.2 & $-10(24)$ & $+5(19)$ & $-5(22)$ & $+4(35)$ & 12 \\
\hline 040205 & LINET centre: anvil_1a* & 1278 & 8 & 24 & 76 & $10.0 \pm 3.4$ & 0.7 & $-15(20)$ & $+5(4)$ & $-8(40)$ & $+5(36)$ & 22 \\
\hline 040205 & LINET centre: anvil_5a** & 439 & 12 & 88 & 12 & $11.6 \pm 3.2$ & 0.7 & $-17(55)$ & $+7(33)$ & $-4(5)$ & $+4(7)$ & 34 \\
\hline 040205 & outside LINET centre: anvil_2b*** & 1466 & 8 & $(55)$ & (45) & $(14.0 \pm 2.5)$ & 0.7 & $-11(34)$ & $+6(21)$ & $-7(25)$ & $+6(20)$ & 21 \\
\hline 250205 & $\begin{array}{l}\text { LINET centre } \\
\text { Transition Trop.-Subtrop. (Brazil) }\end{array}$ & 31221 & 5 & 42 & 58 & $10.3 \pm 3.6$ & 1.5 & $-7(19)$ & $+5(23)$ & $-5(20)$ & $+4(38)$ & 8 \\
\hline 290105 & LINET centre & 419 & 6 & 40 & 60 & $8.6 \pm 3.0$ & 1.3 & $-12(25)$ & $+5(15)$ & $-6(19)$ & $+4(41)$ & 16 \\
\hline 050205 & LINET centre & 1608 & 6 & 66 & 34 & $9.1 \pm 3.3$ & 1.8 & $-9(25)$ & $+6(41)$ & $-5(11)$ & $+5(23)$ & 13 \\
\hline 190205 & $\begin{array}{l}\text { LINET centre } \\
\text { Subtropical (Brazil) }\end{array}$ & 17228 & 5 & 47 & 53 & $9.6 \pm 3.3$ & 1.6 & $-9(21)$ & $+5(26)$ & $-5(17)$ & $+4(36)$ & 9 \\
\hline 180205 & LINET periphery $* * * *$ & 3368 & (13) & - & - & - & 0.5 & - & - & - & - & (57) \\
\hline 180205 & $\begin{array}{l}\text { LINET periphery: anvil I-VI****** } \\
\text { Mid-latitude or Subtr. (Germany) }\end{array}$ & 236 & (13) & - & - & - & 0.6 & - & - & - & - & (55) \\
\hline 290605 & LINET centre: isolated TS & 4232 & 9 & 54 & 46 & $9.3 \pm 2.4$ & 0.6 & $-11(35)$ & $+6(19)$ & $-11(29)$ & $+5(17)$ & 25 \\
\hline 040705 & LINET centre & 6337 & 5 & 72 & 28 & $10.8 \pm 3.3$ & 0.8 & $-6(39)$ & $+4(33)$ & $-6(16)$ & $+4(12)$ & 10 \\
\hline 100705 & LINET centre & 15174 & 6 & 65 & 35 & $9.6 \pm 3.3$ & 0.9 & $-7(36)$ & $+4(29)$ & $-6(17)$ & $+4(18)$ & 12 \\
\hline 150705 & LINET centre & 8607 & 6 & 81 & 19 & $10.2 \pm 3.3$ & 0.8 & $-8(47)$ & $+4(34)$ & $-5(10)$ & $+3(9)$ & 15 \\
\hline 290705 & LINET centre: isolated TS & 2254 & 9 & 76 & 24 & $9.1 \pm 3.4$ & 0.5 & $-12(52)$ & $+6(24)$ & $-8(14)$ & $+4(10)$ & 29 \\
\hline $290705^{4}$ & LINET centre: isolated TS, red. & 1761 & 11 & 81 & 19 & $9.0 \pm 3.5$ & 0.4 & $-13(58)$ & $+7(23)$ & $-11(12)$ & $+6(7)$ & 37 \\
\hline
\end{tabular}

${ }^{1}$ The LINET centre area over Brazil covers $21.5-22.5^{\circ} \mathrm{S}$ and $48.5-49.5^{\circ} \mathrm{W}$ (area with highest detection efficiency).

2 The LINET centre area over Germany covers $48.5-49.5^{\circ} \mathrm{N}$ and $11.0-12.0^{\circ} \mathrm{E}$ (area with highest detection efficiency).

${ }^{3}$ For statistical reasons only days with at least 400 strokes $(\geq 1 \mathrm{kA})$ in the LINET centre area were considered and strokes that were defined as IC or CG strokes (undefined strokes were neglected). The numbers given are the total number of strokes registered between 00:00 and 24:00 UTC or for selected anvils.

${ }^{4}$ Reduced dataset (sensor configuration similar to Brazilian configuration).

*Anvil_1a $\left(21.2-21.7^{\circ} \mathrm{S}\right.$ and $\left.48.9-49.2^{\circ} \mathrm{W}\right)$ is located at the edge of the LINET centre area and partly outside.

**Anvil_5a $\left(21.7-21.9^{\circ} \mathrm{S}\right.$ and $\left.48.4-48.7^{\circ} \mathrm{W}\right)$ is located mainly inside the LINET centre area and comparable to other estimates.

*** Anvil_2b $\left(21.0-21.5^{\circ} \mathrm{S}\right.$ and $\left.49.7-50.1^{\circ} \mathrm{W}\right)$ is located just outside the LINET centre area where the fraction of IC strokes in general decreases, so estimates for this anvil penetration (especially IC height) are not directly comparable to the other estimates.

**** Subtropical thunderstorm system $\left(19.4-20.0^{\circ} \mathrm{S}\right.$ and $\left.47.7-49.2^{\circ} \mathrm{W}, 14: 00-21: 00 \mathrm{UTC}\right)$ is located along the LINET periphery (detection efficiency decreases) and therefore not well comparable to other estimates in this table (where peak currents $\geq 1 \mathrm{kA}$ are considered).

***** Anvil I-VI (19.3-19.8 $\mathrm{S}$ and 48.9-49.2 $\left.{ }^{\circ} \mathrm{W}, 19: 30-21: 00 \mathrm{UTC}\right)$ is located along the LINET periphery (detection efficiency decreases) and therefore not well comparable to other estimates in this table (where peak currents $\geq 1 \mathrm{kA}$ are considered).

where $n_{\mathrm{NO}} \mathrm{ab}(p)$ is the NO production normalised to $1 \mathrm{~m}$ spark length $\left(10^{21}\right.$ molecules $\left.\mathrm{NO} \mathrm{m}^{-1}\right), a=0.34$, and $b=1.30$, and $p$ is the pressure $\left(10^{5} \mathrm{~Pa}\right)$. A laboratory spark at $1000 \mathrm{hPa}$ (ground level) would produce $0.038 \mathrm{gN} \mathrm{m}^{-1}$; at $500 \mathrm{hPa}$ $(300 \mathrm{hPa})$ about $0.023(0.017) \mathrm{gN} \mathrm{m}^{-1}$ would be produced. The average height of IC strokes at mid-latitudes (Table 4a) is $\sim 10.0 \mathrm{~km}(270 \mathrm{hPa})$ and in the tropics $\sim 10.5 \mathrm{~km}(250 \mathrm{hPa})$ (Table 4a). The calculated difference in LNOx production rate (factor 1.1) between these two altitudes $(0.016$ and $0.015 \mathrm{gN} \mathrm{m}^{-1}$, respectively) is only minor and cannot explain the distinctly higher LNOx production rate of subtropical strokes. Only if we make the unrealistic assumption that all subtropical strokes are CG strokes (mean release height $\sim 700 \mathrm{hPa}$ ) and all tropical strokes are IC strokes (mean release height $250 \mathrm{hPa})$ can a factor of $\sim 2(=0.029 / 0.015)$ difference be achieved.

In the last subsection it was concluded that weak strokes with peak currents $<5 \mathrm{kA}$ are less important for the LNOx production. The majority of strokes with peak currents $<5 \mathrm{kA}$ are IC strokes according to the frequency distributions of IC and CG strokes in Fig. 14. These IC strokes are released in the UT at low pressure. Taking this further relationship into account (decreasing LNOx production rate with decreasing pressure), we find that the large number of very weak strokes with peak currents $<5 \mathrm{kA}$ only have a minor contribution to the LNOx budget.

5.3 Comparison of mean stroke peak currents in several tropical and one subtropical Brazilian thunderstorms

The results in the previous subsections lead us to hypothesise that the different stroke lengths (calculated) may mainly contribute to the different LNOx production rates determined for several tropical and one subtropical Brazilian thunderstorms. The contribution from the different stroke peak current frequency distributions was found to be minor, but 
Table 4b. Same as Table $4 \mathrm{a}$, but for strokes with peak currents $\geq 10 \mathrm{kA}$.

\begin{tabular}{|c|c|c|c|c|c|c|c|c|c|c|c|c|}
\hline Date & Type of Thunderstorms/ Area ${ }^{1,2}$ & $\begin{array}{l}\text { Number } \\
\text { of } \\
\text { Strokes }^{3}\end{array}$ & $\begin{array}{l}\text { Mean Peak } \\
\text { Current, } \\
\text { kA }\end{array}$ & $\begin{array}{l}\text { CG } \\
\text { Strokes } \\
\text { (Fraction), } \\
\%\end{array}$ & $\begin{array}{l}\text { IC } \\
\text { Strokes } \\
\text { (Fraction), } \\
\%\end{array}$ & $\begin{array}{l}\text { Height } \\
\text { IC } \\
\text { Strokes, } \\
\text { km }\end{array}$ & $\begin{array}{l}\text { Ratio } \\
\text { Positive/ } \\
\text { Negative } \\
\text { Strokes }\end{array}$ & $\begin{array}{l}\text { Mean Peak } \\
\text { Current } \\
\text { (Fraction) } \\
\text { for CG-, } \\
\text { kA (\%) }\end{array}$ & $\begin{array}{l}\text { Mean Peak } \\
\text { Current } \\
\text { (Fraction) } \\
\text { for CG+, } \\
\text { kA }(\%)\end{array}$ & $\begin{array}{l}\text { Mean Peak } \\
\text { Current } \\
\text { (Fraction) } \\
\text { for IC-, } \\
\text { kA }(\%)\end{array}$ & $\begin{array}{l}\text { Mean Peak } \\
\text { Current } \\
\text { (Fraction) } \\
\text { for IC+, } \\
\text { kA }(\%)\end{array}$ & $\begin{array}{l}\text { Peak } \\
\text { Current } \\
\geq 10 \mathrm{kA} \\
\text { (Fraction), } \\
\%\end{array}$ \\
\hline & Tropical (Brazil) & & & & & & & & & & & \\
\hline 230105 & LINET centre & 1144 & 19 & $<70$ & $\geq 30$ & $10.8 \pm 2.9$ & 0.3 & $-23(57)$ & $+15(13)$ & $-13(18)$ & $+16(12)$ & 30 \\
\hline 240105 & LINET centre & 47 & 19 & 77 & 23 & $10.0 \pm 3.7$ & 0.3 & $-20(66)$ & $+13(11)$ & $-20(11)$ & $+13(12)$ & 28 \\
\hline 250105 & LINET centre & 130 & 21 & 61 & 39 & $9.3 \pm 2.3$ & 0.6 & $-25(42)$ & $+16(19)$ & $-26(19)$ & $+14(20)$ & 31 \\
\hline 040205 & LINET centre & 4379 & 20 & 73 & 27 & $9.5 \pm 3.2$ & 0.3 & $-22(62)$ & $+19(11)$ & $-17(13)$ & $+16(14)$ & 34 \\
\hline 040205 & LINET centre: anvil_1a* & 129 & 18 & 65 & 35 & $10.2 \pm 2.7$ & 0.2 & $-20(62)$ & $+16(3)$ & $-13(24)$ & $+16(11)$ & 26 \\
\hline 040205 & LINET centre: anvil_5 $\mathrm{a}^{* *}$ & 123 & 26 & 98 & 2 & $(8.5 \pm 0.8)$ & 0.1 & $-27(86)$ & $+19(12)$ & $-14(1)$ & $+14(1)$ & 50 \\
\hline 040205 & outside LINET centre: anvil_2b**** & 308 & 19 & 70 & 30 & $(14.2 \pm 2.4)$ & 0.3 & $-22(58)$ & $+14(12)$ & $-16(19)$ & $+16(11)$ & 28 \\
\hline 250205 & $\begin{array}{l}\text { LINET centre } \\
\text { Transition Trop.-Subtrop. (Brazil) }\end{array}$ & 2406 & 18 & 65 & 35 & $11.0 \pm 4.0$ & 0.4 & $-20(50)$ & $+17(15)$ & $-16(20)$ & $+14(15)$ & 24 \\
\hline 290105 & LINET centre & 68 & 18 & 80 & 20 & $8.3 \pm 3.5$ & 0.1 & $-20(74)$ & $+13(6)$ & $-13(16)$ & $+12(4)$ & 31 \\
\hline 050205 & LINET centre & 212 & 22 & 80 & 20 & $8.0 \pm 2.6$ & 0.9 & $-23(45)$ & $+24(35)$ & $-16(8)$ & $+17(12)$ & 33 \\
\hline 190205 & $\begin{array}{l}\text { LINET centre } \\
\text { Subtropical (Brazil) }\end{array}$ & 1499 & 18 & 77 & 23 & $10.2 \pm 3.9$ & 0.4 & $-19(62)$ & $+15(15)$ & $-16(12)$ & $+15(11)$ & 25 \\
\hline 180205 & LINET periphery $* * * *$ & 1914 & 17 & - & - & - & 0.4 & - & - & - & - & 21 \\
\hline 180205 & $\begin{array}{l}\text { LINET periphery: anvil I-VI****** } \\
\text { Mid-latitude or Subtr. (Germany) }\end{array}$ & 130 & 17 & - & - & - & 0.4 & - & - & - & - & 22 \\
\hline 290605 & LINET centre: isolated TS & 1065 & 23 & 56 & 44 & $9.2 \pm 2.3$ & 0.2 & $-24(48)$ & $+24(8)$ & $-24(38)$ & $+16(6)$ & 44 \\
\hline 040705 & LINET centre & 607 & 20 & 71 & 29 & $9.7 \pm 3.0$ & 0.2 & $-19(56)$ & $+26(15)$ & $-18(24)$ & $+23(5)$ & 30 \\
\hline 100705 & LINET centre & 1845 & 20 & 71 & 29 & $9.3 \pm 3.4$ & 0.2 & $-21(60)$ & $+17(11)$ & $-20(23)$ & $+19(6)$ & 32 \\
\hline 150705 & LINET centre & 1253 & 19 & 90 & 10 & $10.3 \pm 3.3$ & 0.1 & $-20(80)$ & $+19(10)$ & $-19(9)$ & $+16(1)$ & 31 \\
\hline 290705 & LINET centre: isolated TS & 659 & 21 & 87 & 13 & $7.4 \pm 3.4$ & 0.1 & $-22(76)$ & $+17(11)$ & $-24(11)$ & $+18(2)$ & 43 \\
\hline $290705^{4}$ & LINET centre: isolated TS, red. & 659 & 21 & 87 & 13 & $7.4 \pm 3.4$ & 0.1 & $-22(76)$ & $+17(11)$ & $-24(11)$ & $+18(2)$ & 43 \\
\hline
\end{tabular}

${ }^{1}$ The LINET centre area over Brazil covers $21.5-22.5^{\circ} \mathrm{S}$ and $48.5-49.5^{\circ} \mathrm{W}$ (area with highest detection efficiency).

2 The LINET centre area over Germany covers $48.5-49.5^{\circ} \mathrm{N}$ and $11.0-12.0^{\circ} \mathrm{E}$ (area with highest detection efficiency).

${ }^{3}$ For statistical reasons only days with at least 40 strokes $(\geq 10 \mathrm{kA})$ in the LINET centre area were considered and strokes that were defined as IC or CG strokes (undefined strokes were neglected). The numbers given are the total number of strokes registered between 00:00 UTC and 24:00 UTC or for selected anvils.

${ }^{4}$ Reduced dataset (sensor configuration similar to Brazilian configuration).

*Anvil_1a $\left(21.2-21.7^{\circ} \mathrm{S}\right.$ and $\left.48.9-49.2^{\circ} \mathrm{W}\right)$ is located at the edge of the LINET centre area and partly outside.

**Anvil_5a $\left(21.7-21.9^{\circ} \mathrm{S}\right.$ and $\left.48.4-48.7^{\circ} \mathrm{W}\right)$ is located mainly inside the LINET centre area and comparable to other estimates.

*** Anvil_2b $\left(21.0-21.5^{\circ} \mathrm{S}\right.$ and $\left.49.7-50.1^{\circ} \mathrm{W}\right)$ is located just outside the LINET centre area where the fraction of IC strokes in general decreases, so estimates for this anvil penetration (especially IC height) are not directly comparable to the other estimates.

**** Subtropical thunderstorm system $\left(19.4-20.0^{\circ} \mathrm{S}\right.$ and $\left.47.7-49.2^{\circ} \mathrm{W}, 14: 00 \mathrm{UTC}-21: 00 \mathrm{UTC}\right)$ is located along the LINET periphery (detection efficiency decreases) but can be compared with the other estimates in this table, since only peak currents $\geq 10 \mathrm{kA}$ are considered here. ***** Anvil I-VI (19.3-19.8 ${ }^{\circ} \mathrm{S}$ and 48.9-49.2 $\left.{ }^{\circ} \mathrm{W}, 19: 30-21: 00 \mathrm{UTC}\right)$ is located along the LINET periphery (detection efficiency decreases) but can be compared with the other estimates in this table, since only peak currents $\geq 10 \mathrm{kA}$ are considered here.

maybe important to explain differences between single tropical thunderstorms as mentioned in Sect. 5.1. In this subsection, values of the mean peak current (also separated for CG and IC strokes) are analysed in detail for a larger number of tropical Brazilian thunderstorms in the period with available LINET measurements (21 January-27 February 2005) to investigate the differences between a number of tropical thunderstorms and the subtropical thunderstorm of 18 February.

For an equivalent comparison only strokes in the centre of the LINET detection network (from $21.5^{\circ} \mathrm{S}$ to $22.5^{\circ} \mathrm{S}$ and $48.5^{\circ} \mathrm{W}$ to $49.5^{\circ} \mathrm{W}, 00: 00-24: 00 \mathrm{UTC}$ ) were considered to avoid changes in detection efficiency and in the IC/CG VLF source ratio towards the border line. Selected days with a large number of LINET strokes suitable for statistical calculations are listed in Table 4a (4b) for peak currents $\geq 1 \mathrm{kA}$ $(\geq 10 \mathrm{kA})$.

The selected days were classified according to $\mathrm{HH} 07$ into different categories: tropical, transition tropical-subtropical and subtropical cases, by use of the meteorological parameters listed in Table $4 \mathrm{c}$ (daily mean values) and as indicated in Fig. 15 ( $3 \mathrm{~h}$ values). In Table $4 \mathrm{c}$ the equivalent potential temperature $\left(\Theta_{e}\right)$ at 850 and $500 \mathrm{hPa}$, and the wind velocity and direction at $200 \mathrm{hPa}$ are listed for the selected LINET days in Table $4 \mathrm{a}-\mathrm{b}$. As suggested in $\mathrm{HH} 07, \Theta_{e}$ in tropical air masses exceeded $345 \mathrm{~K}$ at $850 \mathrm{hPa}$ and $332 \mathrm{~K}$ at $500 \mathrm{hPa}$ and the UT wind velocity was in general low $\sim 5-10 \mathrm{~m} \mathrm{~s}^{-1}$, influenced by the Bolivian High.

The 4 February 2005 was selected as a case representative for tropical thunderstorm activity in general. In the selected region $\sim 36000$ strokes were registered during the whole day (Table 4a). As expected for tropical thunderstorms, the fraction of IC strokes dominates over CG strokes and amounts to at least $57 \%$. The $\geq$ symbol indicates that the fraction of IC strokes may be even larger. The 3-D procedure applied to discriminate between IC and CG strokes categorises some strokes as uncertain. In most cases, this stroke is a CG stroke 
Table 4c. Equivalent potential temperature $\left(\Theta_{e}\right)$ and wind velocity and direction (calculated from ECMWF analyses) in the LINET centre $\operatorname{area}^{1}$ for selected days with LINET strokes as listed in Table $4 \mathrm{a}-\mathrm{b}$.

\begin{tabular}{|c|c|c|c|c|}
\hline Date & $\begin{array}{l}\text { Mean and } \\
\mathrm{Std}^{2} \Theta_{e} \text { at } \\
850 \mathrm{hPa}, \mathrm{K}\end{array}$ & $\begin{array}{l}\text { Mean and } \\
\text { Std } \Theta_{e} \text { at } \\
500 \mathrm{hPa}, \mathrm{K}\end{array}$ & $\begin{array}{l}\text { Mean and Std } \\
\text { Wind Velocity at } \\
200 \mathrm{hPa}, \mathrm{m} \mathrm{s}^{-1}\end{array}$ & $\begin{array}{l}\text { Wind } \\
\text { Direction at } \\
200 \mathrm{hPa}\end{array}$ \\
\hline \multicolumn{5}{|c|}{ Tropical (Brazil) } \\
\hline 230105 & $349 \pm 2$ & $341 \pm 1$ & $11 \pm 3$ & SE \\
\hline 240105 & $349 \pm 2$ & $341 \pm 1$ & $8 \pm 3$ & SE-SW \\
\hline 250105 & $349 \pm 2$ & $343 \pm 1$ & $6 \pm 1$ & SW-NW \\
\hline 040205 & $344 \pm 3$ & $340 \pm 1$ & $5 \pm 2$ & SE-SW \\
\hline 250205 & $342 \pm 4$ & $337 \pm 1$ & $17 \pm 2$ & SW \\
\hline \multicolumn{5}{|c|}{ Transition Tropical-Subtropical (Brazil) } \\
\hline 290105 & $344 \pm 2$ & $342 \pm 2$ & $16 \pm 1$ & $\mathrm{~W}$ \\
\hline 050205 & $343 \pm 2$ & $339 \pm 3$ & $7 \pm 2$ & SW \\
\hline 190205 & $347 \pm 3$ & $330 \pm 2$ & $34 \pm 2$ & $\mathrm{~W}$ \\
\hline \multicolumn{5}{|c|}{ Subtropical (Brazil) } \\
\hline 180205 & $343 \pm 4$ & $330 \pm 1$ & $27 \pm 1$ & $\mathrm{~W}$ \\
\hline \multicolumn{5}{|c|}{ Mid-latitude (Germany) } \\
\hline 290605 & $331 \pm 3$ & $326 \pm 2$ & $21 \pm 2$ & NW-SW \\
\hline 040705 & $323 \pm 6$ & $323 \pm 1$ & $14 \pm 2$ & W-SW \\
\hline 100705 & $321 \pm 3$ & $319 \pm 1$ & $8 \pm 2$ & NE \\
\hline 150705 & $323 \pm 3$ & $320 \pm 1$ & $20 \pm 7$ & NW \\
\hline \multicolumn{5}{|c|}{ Subtropical (Germany) } \\
\hline 290705 & $340 \pm 5$ & $325 \pm 2$ & $19 \pm 3$ & SW \\
\hline
\end{tabular}

1 The LINET centre area over Brazil covers $21.5-22.5^{\circ} \mathrm{S}$ and $48.5-49.5^{\circ} \mathrm{W}$, and over Germany $48.5-49.5^{\circ} \mathrm{N}$ and $11.0-12.0^{\circ} \mathrm{E}$.

${ }^{2}$ Std $=$ Standard deviation.

(and was here defined as CG), but for unfavourable positions of the measuring network stations it cannot be excluded that it is an IC stroke. This uncertainty may lead to significant biases in the results presented below in Table $4 a-b$. Note that we do not deal here with flash counts but with flash component (stroke) counts. In Table $4 \mathrm{a}$ the fraction of positive and negative IC and CG strokes for 4 February (all data) was determined to $\geq 35 \%$ (IC+), $\geq 22 \%$ (IC-), $<24 \%$ (CG-) and $<19 \%$ (CG+). The overall mean peak current (magnitude) was $6 \mathrm{kA}$. The mean peak currents for the different types of strokes (as mentioned above) were $+4,-5,-10$ and $+5 \mathrm{kA}$, respectively. The ratio of positive to negative strokes was 1.2. The mean height of IC strokes was $9.7 \mathrm{~km}$. Furthermore, the last column in Table $4 \mathrm{a}$ indicates that the fraction of peak currents $\geq 10 \mathrm{kA}$ was $12 \%$.

These results from the 4 February tropical thunderstorms can be compared with other tropical thunderstorms (see Table $4 a-b)$ and the 18 February subtropical thunderstorm. In Table $4 \mathrm{a}$ a high mean peak current of $13 \mathrm{kA}$ is given for the 18 February which, however, is not comparable to the rest of the data in Table $4 \mathrm{a}$, since the storm was located along the northern periphery of the LINET network (detection efficiency lower). For an equivalent comparison, only strokes $\geq 10 \mathrm{kA}$, as listed in Table $4 \mathrm{~b}$, were considered and an area along the northern periphery of the LINET detection network (19.4-20.0 ${ }^{\circ} \mathrm{S}$ and 47.7-49.2 ${ }^{\circ} \mathrm{W}$, see Fig. 4b), where the subtropical thunderstorm of 18 February 2005 developed, was selected. The calculated mean peak currents for this area indicate a slightly lower mean peak value, $17 \mathrm{kA}$, for the subtropical thunderstorm of 18 February compared with the mean peak value for tropical thunderstorms of 4 February for the same area, $20 \mathrm{kA}$ (same value as found for the LINET centre area listed in Table $4 \mathrm{~b}$, indicating that the detection efficiency for higher peak currents is about the same in the LINET centre and along the northern periphery, as also discussed in Sect. 4.1).

Overall, the mean peak currents in different tropical thunderstorms of 4 February (and other tropical thunderstorms listed in Table 4b) were highly variable between 18 and $26 \mathrm{kA}$ (probably depending on thunderstorm intensity). In the next section these values are compared with mean peak currents in mid-latitude thunderstorms over Germany to investigate if any major differences exist.

5.4 Comparison of mean stroke peak currents in several tropical and mid-latitude thunderstorms

The LINET network was also operated in southern Germany in summer 2005 (Sect. 2.2). LINET measurements covered an area reaching from $47^{\circ} \mathrm{N}$ to $51^{\circ} \mathrm{N}$ and from $5^{\circ} \mathrm{E}$ to $14^{\circ}$ E. 29 July 2005 was one of the days in summer 2005 with the highest lightning activity over Germany. In the LINET area $\sim 500000$ strokes were registered during the whole day. In Fig. 16a-b the cloud distribution over Europe on this day is shown together with the horizontal distribution 
040205_LINET centre (00-24 UTC)

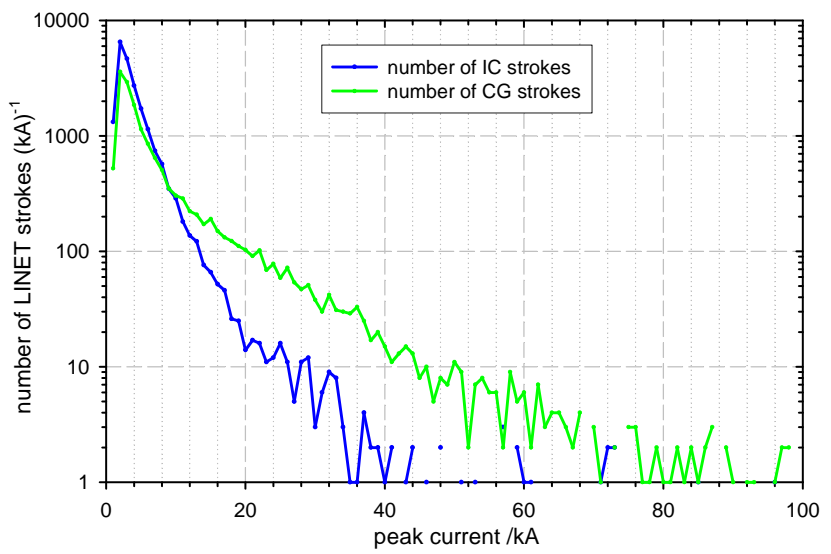

Fig. 14. Frequency distributions of LINET strokes as a function of peak current separated for IC (blue) and CG (green) strokes on 4 February 2005.

of LINET strokes over southern Germany and the positions of the LINET sensors.

For further estimates with LINET data, only data in the LINET centre region were considered (here $48.5^{\circ} \mathrm{N}$ to $49.5^{\circ} \mathrm{N}$ and $11^{\circ} \mathrm{E}$ to $12^{\circ} \mathrm{E}$ ), as mentioned previously. Other days during the German field campaign in June and July 2005 with a high LINET stroke activity in this area were 29 June and 4, 10 and 15 July. The stroke statistics from these days are listed in Table $4 \mathrm{a}-\mathrm{b}$ (for peak currents $\geq 1 \mathrm{kA}$ and $\geq 10 \mathrm{kA}$, respectively) (lower half of table) and can be compared with LINET stroke statistics from Brazil (upper half of table). On 29 June and 29 July strokes in two intense, isolated fast-moving thunderstorms (TS) with high flash rates were considered. On 4, 10 and 15 July all strokes in the LINET centre area were considered. The mean peak currents on the latter days (Table 4a) were 5-6 kA, comparable to the lowest values observed in tropical Brazilian thunderstorms with 5-12 kA (probably lower over Germany owing to the slightly higher detection efficiency in the LINET centre because of a more dense network of LINET sensors). For the same reasons, the fraction of peak currents $\geq 10 \mathrm{kA}$ in these German thunderstorms with $10-15 \%$ was comparable to the lowest values in tropical Brazilian thunderstorms with $8-34 \%$. If only strokes with peak currents $\geq 10 \mathrm{kA}$ are considered, however, (Table 4b), the stroke statistics results from the 4, 10 and 15 July German thunderstorms (mean peak current $19-20 \mathrm{kA}$, ratio of peak currents $\geq 10 \mathrm{kA}$ is $30-32 \%$ ) are within the range for tropical Brazilian thunderstorms (18$26 \mathrm{kA}, 24-50 \%)$.

On 29 June and 29 July 2005 two strong, isolated fast moving thunderstorm systems ahead of cold fronts over Germany with a high stroke frequency were selected, as listed in Table $4 a-b$ and as marked in Fig. $16 b$ for 29 July. In Table $4 a$ the mean peak currents $(\geq 1 \mathrm{kA})$ in these storms were higher
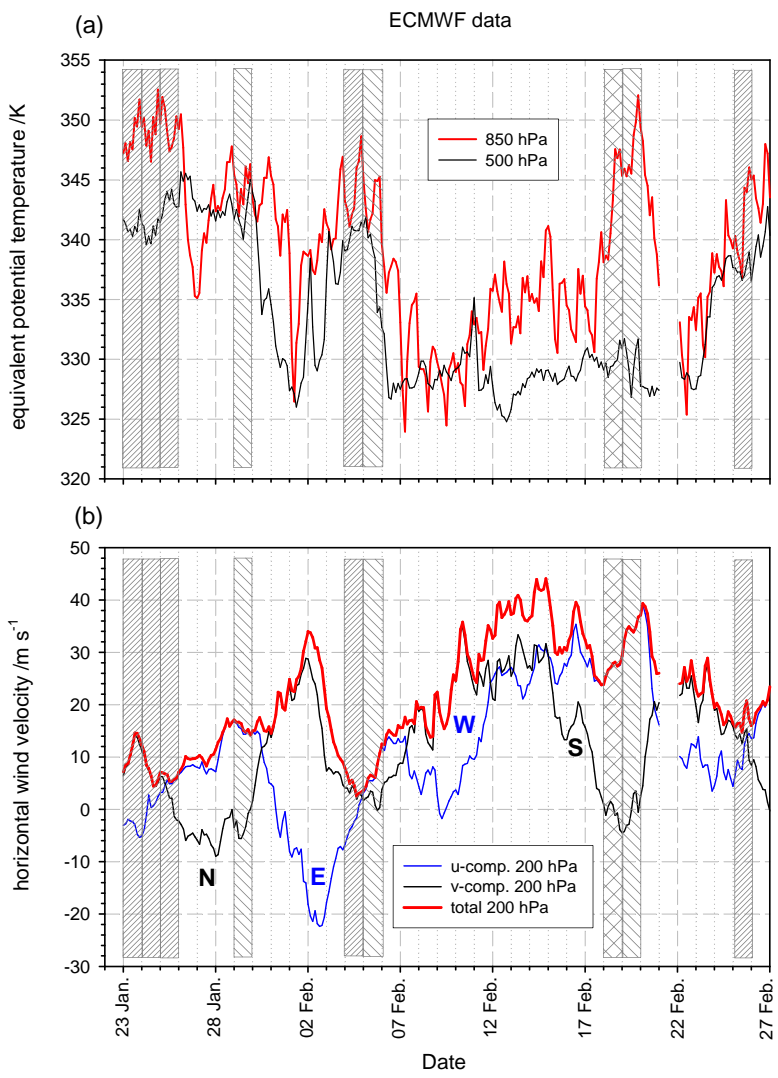

Fig. 15. Time series of (a) equivalent potential temperature and (b) horizontal wind velocity (separated in N, E, W, and S components) at different levels for the period of the TROCCINOX field phase in $2005\left(22^{\circ} \mathrm{S}, 49^{\circ} \mathrm{W}\right)$. Days with registered LINET strokes in the LINET centre area (criterion: at least 40 strokes $\geq 10 \mathrm{kA}$, see Table 4b) are marked with grey patterns (tropical days: dense tilted, transition tropical/subtropical: less dense tilted, subtropical: crossed).

with $9 \mathrm{kA}$ compared with 4, 10 and $15 \mathrm{July}$, and also the ratio of peak currents $\geq 10 \mathrm{kA}$ was higher with 25 and $29 \%$, more similar to the upper values in Brazilian thunderstorms. As expected for mid-latitude thunderstorms (e.g. Prentice and Mackerras, 1977), the fraction of IC strokes $\geq 19-46 \%$ was on average less than in tropical Brazilian thunderstorms and the CG fraction dominated with $<54-81 \%$ (all mid-latitude cases in Table 4 a considered). Furthermore, the mean height of IC strokes was $\sim 0.5 \mathrm{~km}$ lower over Germany compared with Brazil.

To investigate how the different configurations and numbers of sensors over Germany and Brazil influenced the results, an additional dataset was analysed. For all selected German days, a dataset with a reduced number of LINET sensors was created. In the original LINET dataset from 29 July between 5 and 8 sensors (average 7) were considered for the stroke determination in the selected thunderstorm system (indicated in Fig. 16b). In the reduced LINET dataset 
(a)
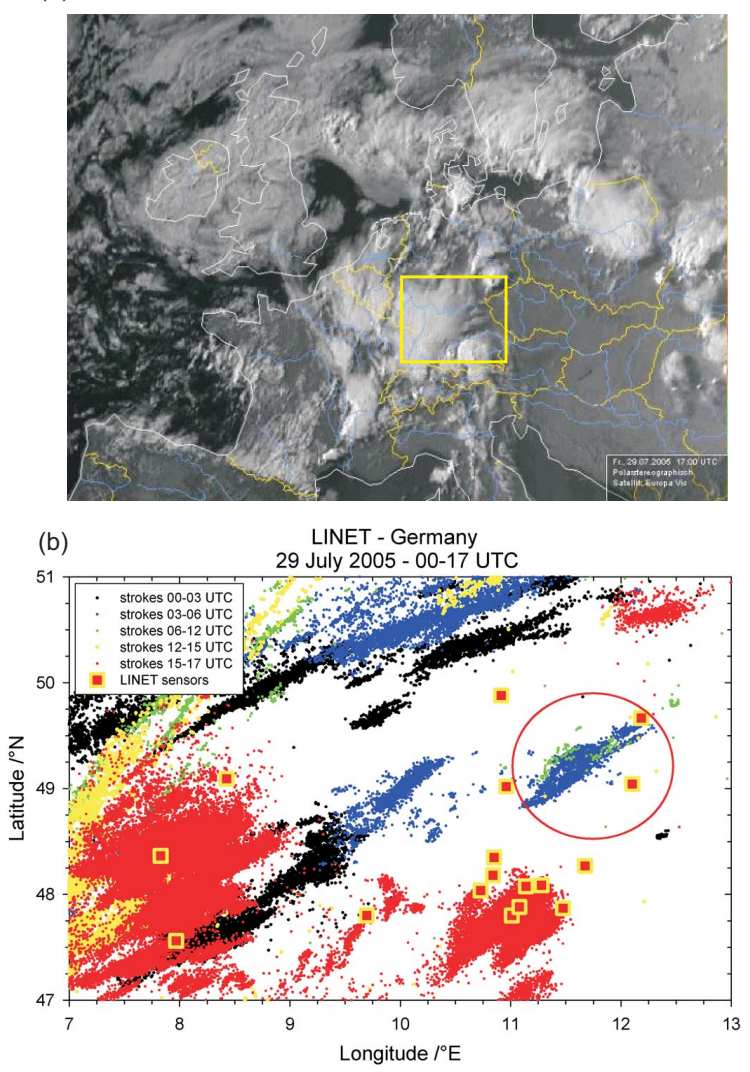

Fig. 16. (a) Visible satellite image (Meteosat, DWD) for 29 July 2005 at 17:00 UTC showing the cloud distribution over Europe. Over southern Germany (mid-latitude) thunderstorms with high cloud tops (white) are visible. The yellow box indicates the area shown in (b); horizontal distribution of LINET strokes for the 29 July 2005, 00:00 UTC-17:00 UTC. In the LINET centre area an isolated thunderstorm system was selected for further investigations (red circle).

between 4 and 6 sensors were used (average 5). The number and position of these sensors were selected to be as similar as possible to the configuration over Brazil (on 4 February four sensors) for an equivalent comparison. The dataset of 29 July with a reduced number of sensors registers fewer strokes and a slightly enhanced mean peak current of $11 \mathrm{kA}$ compared with the original dataset (Table $4 \mathrm{a}$, last line). If only strokes $\geq 10 \mathrm{kA}$ are considered (Table $4 \mathrm{~b}$, last line), however, no differences between the original dataset and the dataset with a reduced number of sensors were found, which is also the case for the rest of the selected German days (not shown). LINET measurements over Brazil and Germany are therefore well comparable (except for the lowest peak currents), in agreement with the findings by Schmidt et al. (2005).

In Fig. 17a frequency distributions of LINET strokes (in the LINET centre area) as a function of peak current for the two different datasets on 29 July are given in colour (for comparison all curves were normalised). The general agree- ment between the two curves in red and blue is good, except that the reduced dataset (lower detection efficiency) registers fewer strokes with low peak currents. The distributions show that strokes with a peak current of 2-3kA were most frequently measured. For comparison, the frequency distribution in tropical thunderstorms over Brazil of 4 February 2005 is also shown (in black). Distinctly more strokes with low peak currents $(<7 \mathrm{kA})$ and fewer high peak currents $(\geq 7 \mathrm{kA})$ were registered in these thunderstorms compared with the selected intense Germany thunderstorm system of 29 July. Next, a larger dataset is used to investigate this observed difference in peak current distributions for selected German and Brazilian thunderstorms.

In Fig. 17b frequency distributions of LINET strokes (all strokes in the LINET centre area) as a function of peak current for different datasets given in colour are shown (for comparison all curves were normalised). Five different datasets are compared: 1.) tropical Brazil (78745 strokes) including 230105, 040205 and 250205 (days with a large number of strokes, as listed in Table 4a-b), 2.) tropical Brazil (36 207 strokes) including only 040205,3 .) mid-latitude Germany (58 543 strokes) including 290605 (here all data), 040705, 100705, 150705 and 290705 (here all data), 4.) mid-latitude Germany (6738 strokes) including only 290605 (selected intense thunderstorm), 5.) mid-latitude Germany (3444 strokes) including only 290705 (selected intense thunderstorm). This comparison shows no distinct differences in general between the stroke frequency distributions over Germany and over Brazil (dark blue and black lines). Again, this result confirms that the two LINET configurations are comparable.

For an estimate of the LNOx mass produced by the observed strokes, the stroke frequency distributions in Fig. 17a were multiplied with the modified Wang et al. (1998) relationship (Eq. 10), as described in Sect. 5.1. In Fig. 17c the estimated amount of NO produced per $1 \mathrm{kA}$ stroke interval for the dataset in Fig. 17a is shown, with different values for the calculated stroke lengths $C_{\text {LINET }}$ (from Table 3 ). The amount of produced NO in Fig. $17 \mathrm{c}$ is a factor $\sim 8$ higher for the selected intense mid-latitude German thunderstorm system of 29 July 2005 (both distributions) compared with tropical Brazilian thunderstorms of 4 February 2005 in general (based on normalised distributions). In this example, the wide range of calculated stroke lengths $(126$ and $30 \mathrm{~km}$, respectively) and stroke peak currents inserted (mean 10 and $6 \mathrm{kA}$, respectively) indicates that a large difference in the LNOx production rate may result in selected cases.

In the tropical Brazilian thunderstorms of 4 February 2005 the majority of the strokes $\sim 90 \%$ have peak currents $<10 \mathrm{kA}$. Figure $17 \mathrm{c}$ indicates that these strokes produce only $\sim 50 \%$ of the total LNOx amount. In addition, $\sim 70 \%$ of all strokes have peak currents $<6 \mathrm{kA}$, but these produce only $30 \%$ of the total LNOx amount. In comparison, in the mid-latitude German intense thunderstorm system of 29 July 2005 , about half of the strokes $(\sim 50 \%)$ have peak currents 
(a)

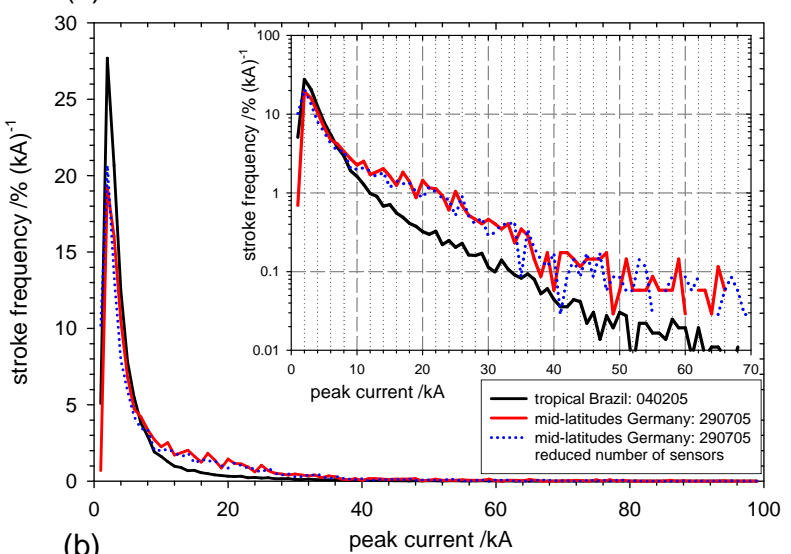

(b)

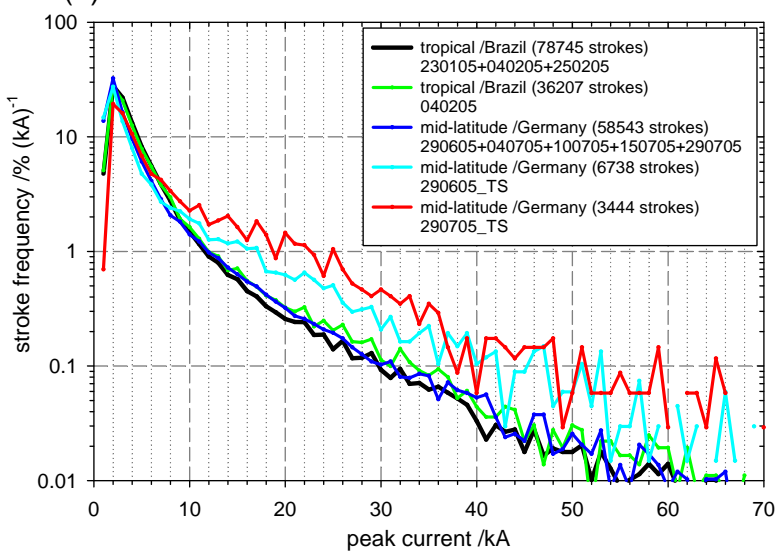

(c)

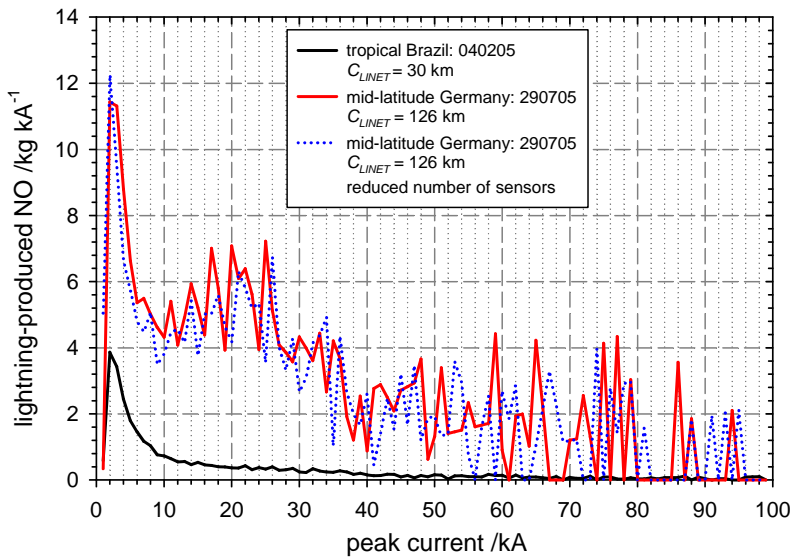

Fig. 17. (a-b) Frequency distributions of LINET strokes (in the LINET centre area) as a function of peak current for different datasets given in colour (for comparison all curves were normalised). (c) Estimated amount of NO produced per $1 \mathrm{kA}$ stroke interval (based on the Wang et al. 1998 relationship) for the dataset in (a) considering different values for $C_{\text {LINET }}$.

$<6 \mathrm{kA}$, but these strokes produce only $\sim 10 \%$ of the LNOx amount. Only a small fraction of all strokes $\sim 10 \%$ have peak currents $>20 \mathrm{kA}$, which produce $\sim 60 \%$ of the total

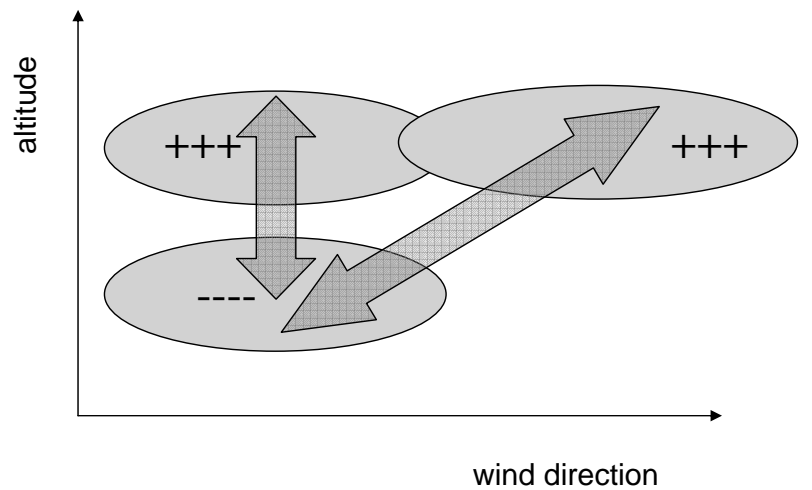

Fig. 18. Schematic illustrating the hypothesis that enhanced vertical wind shear in vicinity of a thunderstorm causes horizontal separation of charged regions (indicated by the ovals with positive charge signs) in the upper parts of a thunderstorm and hence generating longer flashes (arrows) with higher $\mathrm{NO}_{\mathrm{x}}$ production per flash.

LNOx amount. These examples again indicate that the LNOx amount produced by a thunderstorm mainly depends on the number of strokes with peak currents $>5 \mathrm{kA}$.

\section{Discussion}

The results in the previous section indicate that the amount of nitrogen produced by lightning in a thunderstorm is not well correlated with the number of strokes only (Table 3). We suggest, in accordance with Wang et al. (1998) and Barthe et al. (2007), that other lightning parameters such as stroke length, peak current and release height also necessarily have to be taken into account. The amount of nitrogen produced per $\mathrm{m}$ flash and $\mathrm{kA}$ for a given pressure level, see parameter $S$ in Table 3, would be more appropriate for comparison, but all of these parameters are in general not available from operational lightning detection networks. Up to now, all these parameters have not been taken into account concurrently, which may explain the wide range of values for the LNOx production rate per flash given in the literature (SH07). Furthermore, for a more equivalent comparison it would also be desirable to always relate the estimates from a specific lightning detection network to global lightning detection systems such as LIS.

From the analyses of TROCCINOX data, which suggest a higher LNOx production rate for a subtropical thunderstorm compared with several tropical thunderstorms, the stroke length was found to be the most important parameter responsible for the differences. The calculated stroke length was on average a factor $\sim 3$ longer in the investigated subtropical thunderstorm (Table 3). We suggest that the reason for the longer strokes may be related to the enhanced vertical shear in the horizontal wind in this thunderstorm compared with tropical thunderstorms. In the subtropical case, the wind velocity difference between the pressure levels $200 \mathrm{hPa}$ and 

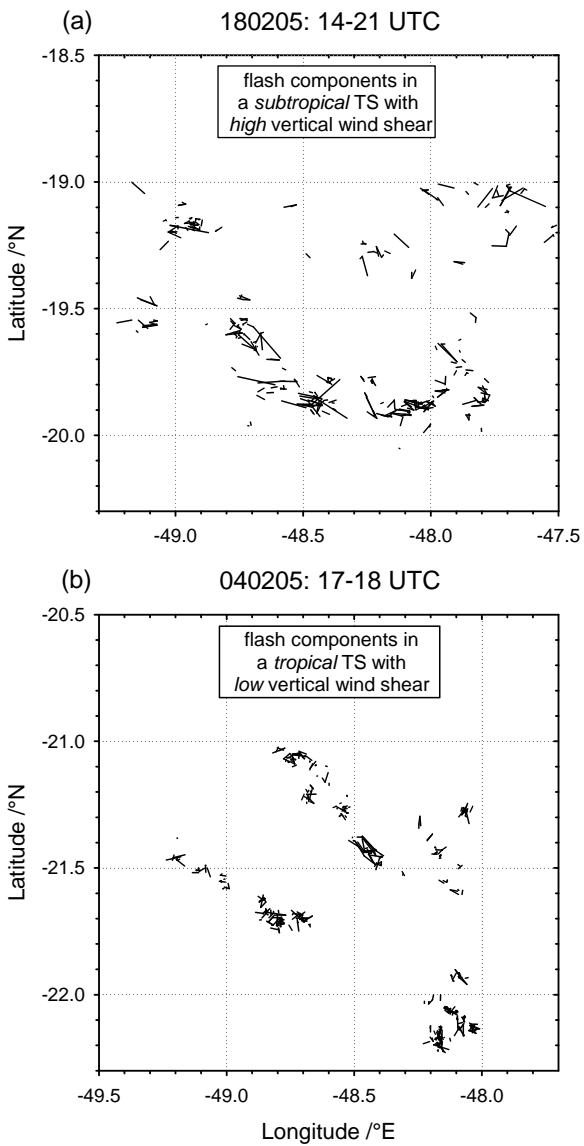

Fig. 19. Horizontal distributions of RINDAT flash components (several VLF sources in a flash connected to a line) for the selected (a) 18 February subtropical thunderstorm (TS) (14:00 UTC-21:00 UTC) and the (b) 4 February tropical thunderstorm (17:00 UTC-18:00 UTC).

$700 \mathrm{hPa}$ is $2-3$ times larger than in the tropical thunderstorm (Table 2a-b, see also Fig. 14 in HH07). The elevated wind velocity in the upper region may distribute charged particles in the subtropical anvil region over longer horizontal distances generating longer flashes, as shown schematically in Fig. 18. Recent simulations by Barthe and Pinty (2007) of an ideal supercellular storm case, using a 3-D mesoscale model with an explicit lightning flash scheme, give some hints in this direction. Furthermore, conceptual models of the electrical structure in a mesoscale convective system (MCS) by Stolzenburg et al. (1994) and in a supercell by Wiens et al. (2005) (both storm types related to elevated wind shear) indicate that the charged regions in the upper part of the cloud may stretch far away from the convective region with precipitation. A lateral displacement of upper level charge on the convective scale $(\sim 10 \mathrm{~km})$ because of vertical wind shear (0-6 km) was first suggested by Pierce (1955), Brook et al. (1982), Ray et al. (1987), and Hill (1988) (known as "tilted dipole mechanism"). Later, observations by En- gholm et al. (1990) of MCS confirmed a tilted deformation of the convective charge centre by the vertical wind shear. Contrarily, Rutledge and MacGorman (1988) first suggested that the origin of charge for positive ground flashes in the trailing-stratiform region of MCSs was the rearward advection of positive charge on large aggregates of ice particles from the MCS convective charge centre (leading line) by the mesoscale storm-relative winds (now known as "charge advection mechanism"). More recently, these mechanisms have also been discussed by Gilmore and Wicker (2002), Carey et al. (2005), Carey and Buffalo (2007) and Steiger et al. $(2007 \mathrm{a}, \mathrm{b})$. However, the VHF lightning observations by Carey et al. (2005) clearly indicate that the "tilted dipole mechanism" and the "charge advection mechanism" are two different mechanism on different scales (convective and mesoscale) that should be considered separately. In summary these references support our hypothesis as shown schematically in Fig. 18.

Unfortunately, for our dataset the actual stroke length cannot be determined from the available lightning data. From the RINDAT data it is possible, however, to compare the length between different VLF sources along a flash ("flash component"). VLF sources within $<1 \mathrm{~s}$ were grouped to a flash component. In Fig. 19a-b the horizontal locations of the flash components are shown for two selected cases. For the 18 February subtropical thunderstorm (strokes considered from 14:00 UTC-21:00 UTC, Fig. 4b) a clear pattern with longer flash components mainly between NW and SE results, influenced by the strong vertical wind shear (Fig. 19a). In contrast, for the 4 February tropical thunderstorms (17:00 UTC-18:00 UTC, Fig. 4a) the horizontal distribution of these flash components shows no preferred direction (Fig. 19b), owing to the lower vertical wind shear. In addition, the flash components are on average shorter compared with the subtropical thunderstorm. The average length of the selected 224 flash components on 4 February was $1.6 \mathrm{~km}$ compared with $3.1 \mathrm{~km}$ on 18 February based on the 173 flash components, a factor 1.9 difference in the lengths.

The thunderstorm observations during TROCCINOX can also be compared with observations in Florida thunderstorms during CRYSTAL-FACE. Ridley et al. (2004) observed that NO mixing ratios in fresh (not heavily polluted) anvils were distinctly higher than observed anywhere else up to then in fresh anvils. Average anvil-NO mixing ratios varied between $\sim 1-4 \mathrm{nmol} \mathrm{mol}^{-1}$, compared with $0.2-1.6 \mathrm{nmol} \mathrm{mol}^{-1} \mathrm{NO}_{\mathrm{x}}$ on average in Brazilian anvils during TROCCINOX (HH07) and $1.3 \pm 0.7 \mathrm{nmol} \mathrm{mol}^{-1} \mathrm{NO}_{\mathrm{x}}$ in more polluted thunderstorms during EULINOX (Huntrieser et al., 2002). For two thunderstorms during CRYSTAL-FACE, Ridley et al. (2004) determined $(3.3-6.6) \times 10^{25}$ and $(17-23) \times 10^{25}$ molecules NO per flash (LIS) for a moderate size and a large storm, respectively. Only the values for the moderate size storm are within the range of the mean value for a subtropical thunderstorm during TROCCINOX: $4.5 \times 10^{25}$ molecules NO per flash (LIS). 
Table 5. Overview over mean peak currents for negative (and partly for all ${ }^{1}$ ) CG flashes measured in different regions (mainly United States = U.S.) indicating a latitudinal gradient as suggested by Orville (1990) and Orville et al. (2002). Higher mean peak currents were estimated in the older studies owing to a lower detection efficiency of low peak currents. The U.S. NLDN was upgraded in 1994-1995 (Cummins et al., 1998) and in 2002-2003 (Cummins et al., 2006).

\begin{tabular}{|c|c|c|c|c|}
\hline $\begin{array}{l}\text { Reference } \\
\text { (chronological) }\end{array}$ & $\begin{array}{l}\text { Lightning Detection } \\
\text { System }\end{array}$ & $\begin{array}{l}\text { Mean Peak } \\
\text { Current CG- } \\
\text { (SE U.S.), kA }\end{array}$ & $\begin{array}{l}\text { Mean Peak Current } \\
\text { CG- (contiguous } \\
\text { U.S.), kA }\end{array}$ & $\begin{array}{l}\text { Mean Peak } \\
\text { Current CG- (N } \\
\text { and Central U.S.), } \\
\text { kA }\end{array}$ \\
\hline Orville (1990) & $\begin{array}{l}\text { NLDN (=National } \\
\text { Lightning Detection } \\
\text { Network): } 1988\end{array}$ & Florida: $40-45^{1}$ & & New England: 25 \\
\hline $\begin{array}{l}\text { Petersen and Rutledge } \\
\text { (1992) }\end{array}$ & $\begin{array}{l}\text { Northern Australia: } \\
\text { 1989-1990 (magnetic } \\
\text { direction-finding } \\
\text { lightning sensors from } \\
\text { U.S.) }\end{array}$ & $\begin{array}{l}\text { Darwin in } \\
\text { tropical northern } \\
\text { Australia: } 39^{1} \\
\text { (similar as in } \\
\text { Florida) }\end{array}$ & & \\
\hline Price et al. (1997) & NLDN: summer 1988 & $\begin{array}{l}\text { Florida and } \\
\text { Midwest: } 36\end{array}$ & & \\
\hline Lyons et al. (1998) & NLDN: 1991-1995 & $\begin{array}{l}\text { Large peak } \\
\text { currents }>75 \text { : } \\
\text { preferable in SE } \\
\text { U.S. }\end{array}$ & & \\
\hline Wacker and Orville (1999) & $\begin{array}{l}\text { NLDN: 1989-1993 } \\
\text { (pre-upgrade) }\end{array}$ & Florida: 41 & contiguous U.S.: 38 & Kansas: 33 \\
\hline Wacker and Orville (1999) & $\begin{array}{l}\text { NLDN: } 1994 \\
\text { (network upgraded) }\end{array}$ & Florida: 36 & contiguous U.S.: 34 & Kansas: 30 \\
\hline Wacker and Orville (1999) & $\begin{array}{l}\text { NLDN: } 1995 \\
\text { (network upgraded) }\end{array}$ & Florida: 33 & contiguous U.S.: 30 & Kansas: 26 \\
\hline Orville and Huffines (1999) & NLDN: 1995-1997 & $\begin{array}{l}\text { continental } \\
\text { coastal areas of } \\
\text { the U.S.: }>26^{2}\end{array}$ & & $\begin{array}{l}\text { mountainous region: } \\
15-20^{2}\end{array}$ \\
\hline DeCaria et al. (2000) & NLDN: 12 July 1996 & & & Colorado: $15^{1}$ \\
\hline Orville et al. (2002) & $\begin{array}{l}\text { NALDN (=North American } \\
\text { Lightning Detection } \\
\text { Network, including Canada } \\
\text { plus contiguous U.S.): } \\
\text { 1998-2000 }\end{array}$ & Florida: $20-24^{2}$ & contiguous U.S.: $16^{2}$ & Central Canada: $12-18^{2}$ \\
\hline Langford et al. (2004) & NLDN: 12 Sep 2002 & & & Colorado: 15 \\
\hline Ridley et al. (2004) & NLDN: 29/16 July 2002 & Florida: $20 / 26$ & & \\
\hline $\begin{array}{l}\text { Chowdhuri et al. (2005) } \\
\text { this paper }\end{array}$ & $\begin{array}{l}\text { NLDN: } 1997-1998 \text { and } 1999-2000 \\
\text { LINET: only CG strokes }<-10 \mathrm{kA}\end{array}$ & $\begin{array}{l}\text { SE U.S.: } 20^{2} \\
\text { Subtropical } \\
\text { Brazil }(18 \text { Feb } \\
\text { 2005): } 19^{3}\end{array}$ & $\begin{array}{l}\text { Mid-latitude } \\
\text { Germany (June- } \\
\text { July 2005): 19-24 }\end{array}$ & $\begin{array}{l}\text { Central/NW U.S.: } 16 / 18^{2} \\
\text { Tropical } \\
\text { Brazil (Jan- } \\
\text { Feb 2005): 19-27 }\end{array}$ \\
\hline
\end{tabular}

${ }^{1}$ Here mean value independent of polarity.

2 Here median value instead of mean value.

${ }^{3}$ Here mean value for negative CG and IC strokes. No separation possible, since strokes occurred along LINET periphery.

The reason for these extreme NO production rates in Florida anvils may be related to a combination of the lightning parameters mentioned above. First, the high flash rate in these storms may play an important role. The high flash density over Florida ( $>9$ flashes $\mathrm{km}^{-2} \mathrm{a}^{-1}$, Orville et al., 2002), however, is comparable to that of Brazil (mean 6-8 flashes and up to 10-15 flashes $\mathrm{km}^{-2} \mathrm{a}^{-1}$ based on NLDN and RINDAT, respectively) (Pinto and Pinto, 2003). Furthermore, it has been reported that the mean peak current of CG flashes is shifted to higher values in Florida thunderstorms compared with other regions in the United States: see mean peak values for different regions listed in Table 5. The NLDN detection efficiency for flashes with peak currents $>5 \mathrm{kA}$ is $80-90 \%$ since the upgrade of the system in 1994-1995 (Cummins et al., 1998) and 90-95\% since the upgrade in 2002-2003 (Cummins et al., 2006). Values based on LINET data are also listed in Table 5 for comparison, which indicate a low mean value in the investigated subtropical 
thunderstorm, but just within the range of mean LINET values for tropical and mid-latitude thunderstorms. In the latter two storm types, the range of the mean peak currents is comparable, but the highest values were observed in tropical thunderstorms. The results presented in Table 5 indicate a latitudinal variation of mean peak current for NLDN, but not for LINET. Finally, the higher wind velocities in the UT over Florida (15 and $20 \mathrm{~m} \mathrm{~s}^{-1}$, Garrett et al., 2005) compared with tropical Brazil indicates that the stroke length may be longer in Florida thunderstorms. We therefore conclude that several lightning parameters, such as flash density, mean peak current and possibly flash length (related to UT wind velocity), achieve especially high values in Florida thunderstorms, which may be responsible for the high anvil-NO mixing ratios and LNOx production rates per stroke observed. Other authors also mentioned that the most severe thunderstorms on earth occur in the central-eastern United States owing to the unique combination of steep lapse rates, moist boundary layer inflow and substantial wind shear (Doswell, 2001; Del Genio et al., 2007).

Furthermore, in our study we find that the LNOx production rate per stroke may be a factor $\sim 2$ (up to 8 ) larger for subtropical and mid-latitude strokes than for tropical strokes (Table 2a, b, Fig. 17c). We therefore suggest that different estimates for the amount of LNOx produced per stroke depending on region are needed for more accurate global LNOx estimates, taking stroke peak currents, stroke release height and stroke lengths (related to the vertical wind shear between upper and lower troposphere) into account. In agreement, recent simulations with the GEOS-CHEM model (Hudman et al., 2007) reveal that upper tropospheric $\mathrm{NO}_{\mathrm{x}}$ mixing ratios observed over the southern United States during ICARTT (July-August 2004) can only be reproduced if the LNOx yield in the model is increased by a factor 4 relative to the Ott et al. (2007) value estimated from EULINOX and other mid-latitude and subtropical storms. For the same model and period Martin et al. (2006) increased northern mid-latitude lightning $\mathrm{NO}_{\mathrm{x}}$ emissions by a factor 4 to fit aircraft observations while tropical lightning $\mathrm{NO}_{\mathrm{x}}$ emissions remained unchanged. Furthermore, preliminary cloud-model results from Pickering et al. (2007) for the 4 February 2005 case suggest that IC flashes in tropical thunderstorms in Brazil produce less LNOx (factor 1.6) compared with previous cloud-model results based on 5 mid-latitude and one subtropical thunderstorms. From our analyses of TROCCINOX data, we suggest that mainly the different vertical wind shear in these regions (as it impacts the stroke length) may explain why different LNOx production rates per stroke are needed in the models.

\section{Summary and conclusions}

During the TROCCINOX field experiment in southern Brazil in the wet season of 2005, lightning-produced $\mathrm{NO}_{\mathrm{x}}$ (LNOx) in and around tropical and subtropical thunderstorms was in- vestigated in large detail with the DLR Falcon and partly with the high-flying M55 Geophysica aircraft. On two selected days (4 and 18 February), enhanced $\mathrm{NO}_{\mathrm{x}}$ mixing ratios in the range of 0.2 to $1.2 \mathrm{nmol} \mathrm{mol}^{-1}$ (width $25-45 \mathrm{~km}$ ) on average were observed during anvil penetrations at $9-11 \mathrm{~km}$ altitudes. The main part of this $\mathrm{NO}_{\mathrm{x}}$ enhancement, $80-90 \%$, was attributed to LNOx while the contribution from the boundary layer (BL) was in general less important (10-20\%). Overall, $\mathrm{NO}_{\mathrm{x}}$ mixing ratios in the anvil outflow region were comparable in magnitude to those measured at mid-latitudes during other campaigns (SH07), but distinctly lower than observed in fresh anvils during CRYSTAL-FACE over Florida, $\sim 1-$ $4 \mathrm{nmol} \mathrm{mol}^{-1} \mathrm{NO}$ (Ridley et al., 2004).

A lightning detection network, LINET, was set up to monitor the local stroke distribution (here VLF sources), which generally agreed well with observations from the operational lightning detection network in Brazil, RINDAT, and with observations from LIS. The horizontal LNOx mass flux in TROCCINOX thunderstorms was estimated from the airborne measurements and trajectory simulations, and combined with LINET stroke rates. The average LNOx production rate per stroke and per LIS flash were estimated. The final results gave $\sim 1$ and $\sim 2-3 \mathrm{~kg}$ per LIS flash for three tropical and one subtropical Brazilian thunderstorms, respectively, suggesting a higher LNOx production rate in the latter storm type (factor $\sim 2$ ). The estimated LNOx production rates were multiplied with the number of LIS flashes occurring globally, 44 flashes $\mathrm{s}^{-1}$. From these values, the mean annual global LNOx production rate was estimated to 1.6 and $3.1 \mathrm{Tg} \mathrm{a}^{-1}$, respectively, from the two storm types mentioned above. These values are well within the range of more recent estimates in SH07. The spread of the results for different thunderstorms penetrations $\left(1.3-3.9 \mathrm{Tg} \mathrm{a}^{-1}\right)$, however, indicates a large variability. This variety mainly results from the extrapolation from single measurements in the anvil outflow, which depends on the aircraft position relative to the thunderstorm core. The large uncertainty $(\sim 320 \%$ relative max. error) in the estimates gives a final range of $0.4-12 \mathrm{Tg} \mathrm{a}^{-1}$.

The analyses from TROCCINOX indicate that the amount of nitrogen produced by lightning in a thunderstorm is not well correlated with the number of strokes only. It is suggested, from laboratory findings by Wang et al. (1998), that other lightning parameters such as stroke length, peak current and release height also necessarily have to be taken into account. Wang et al. (1998) observed a positive correlation between NO production rates per m laboratory spark and stroke peak currents and ambient pressure, which was applied to the present study. According to the first relationship, data from TROCCINOX indicate that the total amount of nitrogen produced by a thunderstorm mainly depends on the number of strokes with peak currents $>5 \mathrm{kA}$. The analyses from TROCCINOX further suggest that the reason for the higher LNOx production rate in the subtropical thunderstorm of 18 February (factor $\sim 2$ ), compared with tropical thunderstorms of 4 February, may be related to the different 
stroke lengths (factor $\sim 3$ longer calculated for the subtropical storm) and is not related to differences in the mean stroke peak current (slightly lower in the subtropical thunderstorm compared with the tropical thunderstorms). Furthermore, the mean IC stroke height was $\sim 0.5 \mathrm{~km}$ lower in the subtropical thunderstorm, though this difference may cause only a minor difference in the LNOx production rate. From these results it was suggested that the longer stroke length in the subtropical thunderstorm may be related to the higher vertical wind shear between 200 and $700 \mathrm{hPa}$ (factor $\sim 2-3$ ), spreading charged particles in the anvil over larger distances. We therefore suggest that the vertical wind shear may be an important parameter influencing the amount of LNOx produced per flash, which has not been taken into account up to now. For future model studies with CTMs, we recommend the incorporation of global meteorological fields of the vertical wind shear to account for the different regional LNOx production rates per stroke. Furthermore, for future field campaigns we suggest using lightning location systems that determine the flash length more precisely (e.g. the French ONERA VHF interferometric mapper or the New Mexico Tech Lightning Mapping Array, LMA).

In addition, a comparison between the lightning activity in TROCCINOX thunderstorms over Brazil and in mid-latitude thunderstorms over Germany was carried out, as measurements with the LINET system were available for both areas in 2005. The stroke frequency distribution as a function of peak current and the range of mean peak currents were in general similar in Brazilian tropical thunderstorms and German mid-latitude thunderstorms. For a selected case, however, it was estimated that the LNOx production rate per LINET stroke may be distinctly higher in intense German mid-latitude thunderstorms compared with tropical Brazilian thunderstorms in general (up to factor $\sim 8$ ), owing to the longer stroke length (related to higher vertical wind shear) and the higher mean peak current in these storms.

Finally, the results from Brazilian thunderstorms during TROCCINOX were compared with Florida thunderstorms during CRYSTAL-FACE, where especially high anvil-NO mixing ratios and LNOx production rates per flash have been observed. Results from the available literature indicate that several lightning parameters, such as flash density, mean peak current and stroke length (related to UT wind velocity), all achieve especially high values in Florida thunderstorms compared with other regions, which we suggest may be responsible for the high NO mixing ratios observed in Florida storms.

We conclude that one advantage of the present study is the use of a lightning location system where the whole spectra of peak currents down to $\sim 1 \mathrm{kA}$ can be detected. In addition, CG and IC strokes can be separated, and measurements with the same system were performed in tropical, subtropical and mid-latitude regions. With this system new insights into the LNOx potential for different types of strokes are possible, but it has to be pointed out that the present study is based on a very limited dataset containing few, random airborne penetrations of single subtropical and tropical thunderstorm systems. Unfortunately, it is not known how representative these measurements are. The main uncertainties originate from the estimate of mean anvil- $\mathrm{NO}_{\mathrm{x}}$ mixing ratios during few anvil penetrations, and from the limited altitude range covered by the aircraft. Also the attribution of the set of observed stroke events (only strokes with peak currents $\geq 10 \mathrm{kA}$ considered) to the LNOx increase is very uncertain. Furthermore, the data were obtained only from a small set of thunderstorm systems over Germany and Brazil. Finally, the scaling between LINET and LIS observations is uncertain because only one short time segment was available to compare both systems directly. Owing to these restrictions the uncertainties in the presented results may be large and the stated generalisations ought to be used with caution. We are aware of the very limited dataset presented in this paper, but with this paper we would like to give a hint in which direction further research concerning measurements of LNOx in the field could take. Recently during AMMA (August 2006), the anvil outflow from African thunderstorms was probed with several aircraft. In addition, recent measurements in tropical thunderstorms over Australia (Darwin) from the SCOUT campaign in December 2005 can be investigated in the same manner as presented in this paper. During both field experiments lightning measurements were carried out with the LINET system.

Even though the majority of global lightning occurs in the tropics (Christian et al., 2003), our study suggests that subtropical and mid-latitude thunderstorms may contribute with an essential fraction to global LNOx, since we observe a tendency that the stroke length (related to the vertical wind shear) is longer in these storms. As a result, more LNOx may be produced per stroke in these storms with elevated vertical wind shear compared with tropical low-shear thunderstorms as observed over Brazil. Finally, we would like to point out that the estimated amount of LNOx produced per flash, as given in many studies (SH07), largely depends on the type of lightning detection system used and therefore these estimates should be compared more carefully in future. Furthermore, the relationship between the used lightning system and LIS must be known if the values are scaled up with the annual global LIS flash rate $\left(44 \mathrm{~s}^{-1}\right)$, as demonstrated in this paper.

Acknowledgements. TROCCINOX was partially funded by the Commission of the European Community under the contract EVK2-CT-2001-00122 and by the DLR (Deutsches Zentrum für Luft- und Raumfahrt) and other TROCCINOX partners. TROCCINOX was performed as a coordinated action of European and Brazilian research institutes and agencies together with the Brazilian project Tropical Convection and Cirrus Experiment Brazil (TroCCiBras), see detailed acknowledgements in HH07. Furthermore, we are especially grateful to A. Minikin for his contribution to flight planning and his work as mission scientist on some of the flights, to A. Roiger, M. Lichtenstern and P. Stock (DLR-Oberpfaffenhofen) for instrument preparation, to C. Schwierz (ETH-Zurich) for meteorological support during the 
field campaign and post-campaign meteorological analyses and to A. Stohl (NILU-Kjeller) for post-campaign meteorological analyses and helpful comments on draft manuscripts. We thank the Falcon pilots (M. Grossrubatscher, D. Günther, M. Hinterwaldner and $\mathrm{R}$. Welser), engineers and scientists of the flight department of DLR for the excellent support during the campaigns and the Geophysica team (especially P. Mazzinghi, F. D'Amato and S. Viciani, INOA/CNR, for the CO measurements). Further, T. Fehr (DLR), the Brazilian IPMet team and K. Schmidt, B. Fuchs and W. P. Oettinger from the LINET team (University of Munich) are greatly acknowledged for setting up and running the LINET system in Brazil and Germany. We thank P. S. Borges (IPMet, São Paolo State University/UNESP, Bauru) for preparing the radar images from southern Brazil. We express our gratitude to the lightning team at MSFC-NASA for the access to the LIS data. The European Centre for Medium Weather Forecasts (ECMWF) and the German Weather Service (DWD) are acknowledged for permitting access to the ECMWF archives. Finally, we are especially grateful to the two anonymous reviewers for their helpful comments, and to E. Defer (LERMA, Observatoire de Paris) and K. Pickering (NASA Goddard Space Flight Center Greenbelt) who critically reviewed draft manuscripts and gave insightful comments and helpful suggestions for the data analysis.

Edited by: M. G. Lawrence

\section{References}

Barth, M. C., Kim, S.-W., Wang, C., et al.: Cloud-scale model intercomparison of chemical constituent transport in deep convection, Atmos. Chem. Phys. Discuss., 7, 8035-8085, 2007, http://www.atmos-chem-phys-discuss.net/7/8035/2007/.

Barthe, C. and Pinty, J.-P.: Simulation of a supercellular storm using a three-dimensional mesoscale model with an explicit lightning flash scheme, J. Geophys. Res., 112, D06210, doi:10.1029/2006JD007484, 2007.

Barthe, C., Pinty, J.-P., and Mari, C.: Lightning-produced $\mathrm{NO}_{\mathrm{x}}$ in an explicit electrical scheme tested in a Stratosphere-Troposphere Experiment: Radiation, Aerosols, and Ozone case study, J. Geophys. Res., 112, D04302, doi:10.1029/2006JD007402, 2007.

Beirle, S., Platt, U., Wenig, M., and Wagner, T.; $\mathrm{NO}_{\mathrm{x}}$ production by lightning estimated with GOME, Adv. Space Res., 34, 793-797, 2004.

Beirle, S., Spichtinger, N., Stohl, A., Cummins, K. L., Turner, T., Boccippio, D., Cooper, O. R., Wenig, M., Grzegorski, M., Platt, U., and Wagner, T.: Estimating the $\mathrm{NO}_{\mathrm{x}}$ produced by lightning from GOME and NLDN data: a case study in the Gulf of Mexico, Atmos. Chem. Phys., 6, 1075-1089, 2006, http://www.atmos-chem-phys.net/6/1075/2006/.

Bertram, T. H., Perring, A. E., Wooldridge, P. J., et al.: Direct measurements of the convective recycling of the upper troposphere, Science, 315, 816-820, 2007.

Betz, H.-D., Schmidt, K., Oettinger, W. P., and Wirz, M.: Lightning detection with 3D-discrimination of intracloud and cloud-to-ground discharges, Geophys. Res. Lett., 31, L11108, doi:10.1029/2004GL019821, 2004.

Betz, H.-D., Schmidt, K., Fuchs, B., Oettinger, W. P., and Höller, H.: Cloud lightning: Detection and utilization for total lightning measured in the VLF/LF regime, J. Lightning Res., 2, 1-17, http: //www.jorl.org., 2007a.

Betz, H.-D., Schmidt, K., Laroche, P., Blanchet, P., Oettinger W. P., and Defer, E.: LINET - A New Lightning Detection Network in Europe, 13th Int. Conf. on Atmospheric Electricity, Beijing, 13-18 August 2007b.

Boccippio, D. J., Koshak, W. J., and Blakeslee, R. J.: Performance assessment of the tropical transient detector and lightning imaging sensor. Part I: Predicted diurnal variability, J. Atmos. Oceanic Technol., 19, 1318-1332, 2002.

Boersma, K. F., Eskes, H. J., Meijer, E. W., and Kelder, H. M.: Estimates of lightning $\mathrm{NO}_{\mathrm{x}}$ production from GOME satellite observations, Atmos. Chem. Phys., 5, 2311-2331, 2005, http://www.atmos-chem-phys.net/5/2311/2005/.

Bögel, W. and Baumann, R.: Test and calibration of the DLR Falcon wind measuring system by maneuvers, J. Atmos. Oceanic Technol., 8, 5-18, 1991.

Bradshaw, J., Davis, D., Grodzinsky, G., Smyth, S., Newell, R., Sandholm, S., and Liu, S.: Observed distributions of nitrogen oxides in the remote free troposphere from the NASA global tropospheric experiment programs, Rev. Geophys., 38, 61-116, 2000.

Brook, M., Nakano, M., Krehbiel, P., and Takeuti, T: The electrical structure of the Hokuriku winter thunderstorms, J. Geophys. Res., 87, 1207-1215, 1982.

Carey, L. D., Murphy, M. J., McCormick, T. L., and Demetriades, N. W. S.: Lightning location relative to storm structure in a leading-line, trailing-stratiform mesoscale convective system, J. Geophys. Res., 110, D03105, doi:10.1029/2003JD004371, 2005.

Carey, L. D. and Buffalo, K. M.: Environmental control of cloud-toground lightning polarity in severe storms, Mon. Weather Rev., 135, 1327-1353, 2007.

Chaboureau, J.-P., Cammas, J.-P., Duron, J., Mascart, P. J., Sitnikov, N., and Voessing, H.-J.: A numerical study of tropical crosstropopause transport by convective overshoots, Atmos. Chem. Phys., 7, 1731-1740, 2007,

http://www.atmos-chem-phys.net/7/1731/2007/.

Chameides, W. L.: The role of lightning in the chemistry of the atmosphere, in The Earth's Electrical Environment, pp. 70-77, Nat. Acad. Press, Washington, D.C., 1986.

Chameides, W. L., Davis, D. D., Bradshaw, J., Rodgers, M., Sandholm, S., and Bai, D. B.: An estimate of the $\mathrm{NO}_{\mathrm{x}}$ production rate in electrified clouds based on NO observations from the GTE/CITE 1 fall 1983 field operation, J. Geophys. Res., 92, 2153-2156, 1987.

Chowdhuri, P., Anderson, J. G., Chisholm W. A., et al.: Parameters of lightning strokes: A Review, IEEE Transactions on Power Delivery, 20(1), 346-358, 2005.

Christian, H. J., Blakeslee, R. J., Goodman, S. J., et al.: The Lightning Imaging Sensor, Proceedings of the 11th International Conference on Atmospheric Electricity, Guntersville, Alabama, 7-11 June 1999, 746-749, 1999.

Christian, H. J., Blakeslee, R. J., Boccippio, D. J., et al.: Global frequency and distribution of lightning as observed from space by the Optical Transient Detector, J. Geophys. Res., 108, 4005, doi:10.1029/2002JD002347, 2003.

Christian, H. J. and Petersen, W.: Global lightning activity, Conference on Meteorological Applications of Lightning Data, 85th AMS Annual Meeting, San Diego, CA, 10-12 January 2005.

Cooper, O. R., Stohl, A., Trainer, M., et al.: Large upper tropo- 
spheric ozone enhancements above mid-latitude North America during summer: In situ evidence from the IONS and MOZAIC ozone measurement network, J. Geophys. Res., 111, D24S05, doi:10.1029/2006JD007306, 2006.

Coppens, F., Berton, R., Bondiou-Clergerie, A., and Gallimberti, I.: Theoretical estimate of $\mathrm{NO}_{\mathrm{x}}$ production in lightning corona, $\mathrm{J}$. Geophys. Res., 103, 10 769-10 785, 1998.

Cummins, K. L., Murphy, M. J., Bardo, E. A., Hiscox, W. L., Pyle, R. B., and Pifer, A. E.: A combined TOA/MDF technology upgrade of the U.S. National Lightning Detection Network, J. Geophys. Res., 103, 9035-9044, doi:10.1029/98JD00153, 1998.

Cummins, K., Cramer, J. A., Biagi, C. J., Krider, E. P., Jerauld, J., Uman, M. A., and Rakov, V. A.: The U.S. national lightning detection network: post-upgrade status, The 86th AMS Annual Meeting, 2nd Conference on Meteorological Applications of Lightning Data, Paper 6.1, 28 January-3 February 2006, Atlanta, GA, 2006.

DeCaria, A. J., Pickering, K. E., Stenchikov, G. L., Scala, J. R., Stith, J. L., Dye, J. E., Ridley, B. A., and Laroche, P.: A cloud-scale model study of lightning-generated $\mathrm{NO}_{\mathrm{x}}$ in an individual thunderstorm during STERAO-A, J. Geophys. Res., 105, 11 601-11 616, 2000.

DeCaria, A. J., Pickering, K. E., Stenchikov, G. L., and Ott, L. E.: Lightning-generated $\mathrm{NO}_{\mathrm{x}}$ and its impact on tropospheric ozone production: A three-dimensional modelling study of a Stratosphere-Troposphere Experiment: Radiation, Aerosols, and Ozone (STERAO-A) thunderstorm, J. Geophys. Res., 110, D14303, doi:10.1029/2004JD005556, 2005.

Defer, E., Laroche, P., Dye, J. E., and Skamarock, W.: Use of total lightning lengths to estimate $\mathrm{NO}_{\mathrm{x}}$ production in a Colorado thunderstorm, paper presented at 12th International Conference on Atmospheric Electricity, 9-13 June, Int. Comm. on Atmos. Electr., Versailles, France, 2003.

Del Genio, A. D., Yao, M.-S., and Jonas, J.: Will moist convection be stronger in a warmer climate?, Geophys. Res. Lett., 34, L16703, doi:10.1029/2007GL030525, 2007.

Dickerson, R. R., Huffman, G. J., Luke, W. T., et al.: Thunderstorms: An important mechanism in the transport of air pollutants, Science, 235, 460-465, 1987.

Doswell III, C. A.: Severe Convective Storms, Meteorol. Monogr. Ser., vol. 28(50), 570 pp., Am. Meteorol. Soc., Boston, Mass., USA, 2001.

Dye, J. E., Ridley, B. A., Skamarock, W., et al.: An overview of the Stratospheric-Tropospheric Experiment: Radiation, aerosols, and ozone (STERAO)-Deep convection experiment with results for the July 10, 1996 storm, J. Geophys. Res, 105, 10023 $10045,2000$.

Engholm, C. D., Williams, E. R., and Dole R. M.: Meteorological and electrical conditions associated with positive cloud-toground lightning, Mon. Weather Rev., 118, 470-487, 1990.

Fehr, T., Höller, H., and Huntrieser, H.: Model study on production and transport of lightning-produced $\mathrm{NO}_{\mathrm{x}}$ in an EULINOX supercell storm, J. Geophys. Res., 109, D09102, doi:10.1029/2003JD003935, 2004.

Gallardo, L. and Cooray, V.: Could cloud-to-cloud discharges be as effective as cloud-to-ground discharges in producing $\mathrm{NO}_{\mathrm{x}}$ ?, Tellus, 48B, 641-651, 1996.

Garrett, T. J., Navarro, B. C., Twohy, C. H., et al.: Evolution of a Florida cirrus anvil, J. Atmos. Sci., 62, 2352-2372, 2005.
Gilmore, M. S. and Wicker, L. J.: Influences of the local environment on supercell cloud-to-ground lightning, radar characteristics, and severe weather on 2 June 1995, Mon. Weather Rev., 130, 2349-2372, 2002.

Hauf, T., Schulte, P., Alheit, R., and Schlager, H.: Rapid vertical trace gas transport by an isolated mid-latitude thunderstorm, J. Geophys. Res., 100, 22 957-22 970, 1995.

Hill, R. D.: Interpretation of bipole patterns in a mesoscale storm, Geophys. Res. Lett., 23, 643-645, 1988.

Höller, H., Finke, U., Huntrieser, H., Hagen, M., and Feigl, C.: Lightning produced $\mathrm{NO}_{\mathrm{x}}(\mathrm{LINOX})$ - Experimental design and case study results, J. Geophys. Res., 104, 13 911-13 922, 1999.

Hudman, R. C., Jacob, D. J., Turquety, S., et al.: Surface and lightning sources of nitrogen oxides in the United States: Magnitudes, chemical evolution, and outflow, J. Geophys. Res., 112, D12S05, doi:10.1029/2006JD007912, 2007.

Huntrieser, H., Schlager, H., Feigl, C., and Höller, H.: Transport and production of $\mathrm{NO}_{\mathrm{x}}$ in electrified thunderstorms: Survey of previous studies and new observations at mid-latitudes. J. Geophys. Res., 103, 28 247-28 264, 1998.

Huntrieser, H., Feigl, C., Schlager, H., Schröder, F., Gerbig, C., van Velthoven, P., Flatøy, F., Théry, C., Petzold, A., Höller, H., and Schumann, U.: Airborne measurements of $\mathrm{NO}_{\mathrm{x}}$, tracer species and small particles during the European Lightning Nitrogen Oxides Experiment, J. Geophys. Res., 107(D11), 4113, doi:10.1029/2000JD000209, ACH 5-1-ACH 5-24, 2002.

Huntrieser, H., Heland, J., Schlager, H., et al.: Intercontinental air pollution transport from North America to Europe: Experimental evidence from airborne measurements and surface observations, J. Geophys. Res., 110, D01305, doi:10.1029/2004JD005045, 2005.

Huntrieser, H., Schlager, H., Höller, H., Schumann, U., Betz, H.-D., Boccippio, D., Brunner, D., Forster, C., and Stohl, A.: Lightningproduced $\mathrm{NO}_{\mathrm{x}}$ in tropical, subtropical and mid-latitude thunderstorms: New insights from airborne and lightning observations, European Geosciences Union, General Assembly 2006, Vienna, Austria, 2-7 April 2006, Oral Paper Nr. EGU06-A-03286, Geophys. Res. Abstracts, vol. 8, 2006.

Huntrieser, H., Schlager, H., Roiger, A., Schumann, U., Höller, H., Kurz, C., Brunner, D., Schwierz, C., Richter, A., and Stohl, A.: Lightning-produced $\mathrm{NO}_{\mathrm{x}}$ over Brazil during TROCCINOX: airborne measurements in tropical and subtropical thunderstorms and the importance of mesoscale convective systems, Atmos. Chem. Phys., 7, 2987-3013, 2007,

http://www.atmos-chem-phys.net/7/2987/2007/.

Jerauld, J., Rakov, V. A., Uman, M. A., Rambo, K. J., Jordan, D. M., Cummins, K. L., and Cramer, J. A.: An evaluation of the performance characteristics of the U.S. National Lightning Detection Network in Florida using rocket-triggered lightning, J. Geophys. Res., 110, D19106, doi:10.1029/2005JD005924, 2005.

Keenan, T. D. and Carbone, R. E.: A preliminary morphology of precipitation systems in tropical northern Australia, Q. J. Roy. Meteorol. Soc., 118, 283-326, 1992.

Koike, M., Kondo, Y., Kita, K., et al.: Measurements of reactive nitrogen produced by tropical thunderstorms during BIBLE-C, J. Geophys. Res., 112, D18304, doi:10.1029/2006JD008193, 2007.

Langford, A. O., Portmann, R. W., Daniel, J. S., Miller, H. L., and Solomon, S.: Spectroscopic measurements of $\mathrm{NO}_{2}$ in a Colorado thunderstorm: Determination of the mean production by cloud- 
to-ground lightning flashes, J. Geophys. Res., 109, D11304, doi:10.1029/2003JD004158, 2004.

Lopez, J. P., Fridlind, A. M., Jost, H.-J., et al.: CO signatures in subtropical convective clouds and anvils during CRYSTAL-FACE: An analysis of convective transport and entrainment using observations and a cloud-resolving model, J. Geophys. Res., 111, D09305, doi:10.1029/2005JD006104, 2006.

Lyons, W. A., Uliasz, M., and Nelson, T. E.: Large peak current cloud-to-ground lightning flashes during the summer months in the contiguous United States, Mon. Weather Rev., 126, $2217-$ 2233, 1998.

Martin, R. V., Sioris, C. E., Chance, K., et al.: Evaluation of space-based constraints on global nitrogen oxide emissions with regional aircraft measurements over and downwind of eastern North America, J. Geophys. Res., 111, D15308, doi:10.1029/2005JD006680, 2006.

Martin, R. V., Sauvage, B., Folkins, I., et al.: Space-based constraints on the production of nitric oxide by lightning, J. Geophys. Res., 112, D09309, doi:10.1029/2006JD007831, 2007.

Orville, R. E.: Peak-current variations of lightning return strokes as a function of latitude, Nature, 343, 149-151, 1990.

Orville, R. E.: Comments on "Large peak current cloud-to-ground lightning flashes during the summer months in the contiguous United States", Mon. Weather Rev., 127, 1937-1938, 1999.

Orville, R. E. and Huffines, G. R.: Lightning ground flash measurements over the contiguous United States: 1995-1997, Mon. Weather Rev., 127, 2693-2703, 1999.

Orville, R. E., Huffines, G. R., Burrows, W. R., Holle, R. L., and Cummins, K. L.: The North American lightning detection network (NALDN) - First results: 1998-2000, Mon. Weather Rev., 130, 2098-2109, 2002.

Ott, L. E., Pickering, K. E., Stenchikov, G. L., Huntrieser, H., and Schumann, U.: Effects of lightning $\mathrm{NO}_{\mathrm{x}}$ production during the July 21 European Lightning Nitrogen Oxides Project storm studied with a three-dimensional cloud-scale chemical transport model, J. Geophys. Res., 112, D05307, doi:10.1029/2006JD007365, 2007.

Petersen, W. A. and Rutledge, S. A.: Some characteristics of cloudto-ground lightning in tropical northern Australia, J. Geophys. Res., 97, 11 553-11 560, 1992.

Petersen, W. A., Christian, H. J., and Rutledge, S. A.: TRMM observations of the global relationship between ice water content and lightning, Geophys. Res. Lett., 32, L14819, doi:10.1029/2005GL023236, 2005.

Pickering, K. E., Thompson, A. M., Scala, J. R., Tao, W.-K., Dickerson, R. R., and Simpson, J.: Free tropospheric ozone production following entrainment of urban plumes into deep convection, J. Geophys. Res., 97, 17 985-18 000, 1992.

Pickering, K. E., Thompson, A. M., Wang, Y., et al.: Convective transport of biomass burning emissions over Brazil during TRACE A, J. Geophys. Res., 101, 23 993-24 012, 1996.

Pickering, K. E., Wang, Y., Tao, W.-K., Price, C., and Müller, J.F.: Vertical distributions of lightning $\mathrm{NO}_{\mathrm{x}}$ for use in regional and global chemical transport models, J. Geophys. Res., 103, 31203 $31216,1998$.

Pickering, K. E., Huntemann, T., Ott, L., Barth, M., Huntrieser, H., Schlager, H., Schumann, U., Vaughan, G., and Volz-Thomas, A.: Cloud-resolved simulations of lightning- $\mathrm{NO}_{\mathrm{x}}$ in observed tropical thunderstorms, European Geosciences Union, General As- sembly 2007, Vienna, Austria, 15-20 April 2007, Oral Paper Nr. EGU2007-A-11013, Geophys. Res. Abstr., vol. 9, 2007.

Pierce, E. T.: The development of lightning discharges, Q. J. Roy. Meteor. Soc., 81, 229-240, 1955.

Pinto, I. R. C. A. and Pinto Jr., O.: Cloud-to-ground lightning distributions in Brazil, J. Atmos. Solar-Terr. Phys., 65, 733-737, 2003.

Pinto Jr., O., Pinto, I. R. C. A., and Naccarato, K. P.: Maximum cloud-to-ground lightning flash densities observed by lightning location systems in the tropical region: A review, Atmos. Res., 84, 189-200, 2007.

Price, C., Penner, J., and Prather, $\mathrm{M} .: \mathrm{NO}_{\mathrm{x}}$ from lightning: 1. Global distribution based on lightning physics, J. Geophys. Res., 102, 5929-5941, 1997.

Prentice, S. A. and Mackerras, D.: The ratio of cloud to cloudground lightning flashes in thunderstorms, J. Appl. Meteorol., 16, 545-550, 1977.

Rahman, M., Corray, V., Rakov, V. A., Uman, M. A., Liyanage, P., DeCarlo B. A., Jerauld, J., and Olsen III, R. C.: Measurements of $\mathrm{NO}_{\mathrm{x}}$ produced by rocket-triggered lightning, Geophys. Res. Lett., 34, L03816, doi:10.1029/2006GL027956, 2007.

Rakov, V. A., Thottapillil, R., and Uman, M. A.: On the empirical formula of Willett et al. relating lightning return-stroke peak current and peak electric field, J. Geophys. Res., 97, 11 527-11 533, 1992.

Ray, P. S, MacGorman, D. R., Rust, W. D., Taylor, W. L., and Rasmussen, L. W.: Lightning location relative to storm structure in a supercell storm and a multicell storm, J. Geophys. Res., 92, 5713-5724, 1987.

Ridley, B. A., Dye, J. E., Walega, J. G., Zheng, J., Grahek, F. E., and Rison, W.: On the production of active nitrogen by thunderstorms over New Mexico, J. Geophys. Res., 101, 20 985-21 005, 1996.

Ridley, B. A., Ott, L., Pickering, K., et al.: Florida thunderstorms: A faucet of reactive nitrogen to the upper troposphere, J. Geophys. Res., 109, D17305, doi:10.1029/2004JD004769, 2004.

Ridley, B. A., Pickering, K. E., and Dye, J. E.: Comments on the parameterization of lightning-produced NO in global chemistrytransport models, Atmos. Environ., 39, 6184-6187, 2005.

Rutledge, S. A. and MacGorman, D. R.: Cloud-to-ground lightning activity in the 10-11 June 1985 mesoscale convective system observed during the Oklahoma-Kansas PRE-STORM project, Mon. Weather Rev., 116, 1393-1408, 1988.

Schmidt, K., Betz, H.-D., Oettinger, W. P., Wirz, M., and Diendorfer, G.: A new lightning detection network in southern Germany, 27th International Conference on Lightning Protection (ICLP), September 2004, Avignon, France, 2004.

Schmidt, K., Betz, H.-D., Oettinger, W. P., Wirz, M., Pinto Jr., O., Naccarato, K. P., Höller, H., Fehr, T., and Held, G.: A comparative analysis of lightning data during the EU-Brazil TROCCINOX/TroCCiBras campaign, VIII International Symposium on Lightning Protection (SIPDA), 21-25 November 2005, São Paulo, Brazil, 2005.

Schmidt, K.: Ortung und Analyse von Blitzentladungen mittels Registrierung von VLF-Atmospherics innerhalb eines Messnetzes, Ph.D. thesis, Ludwig-Maximilians-Universität, Munich, Germany, 2007.

Schmidt, K., Betz, H.-D., Fuchs, B., Meyer, V., Laroche, P., Blanchet, P., Oettinger, W. P., and Defer, E.: Detection of low- 
amplitude lightning with LINET in Europe, 13th Int. Conf. on Atmospheric Electricity, Aug. 13-18, Beijing, 2007.

Schulz, W., Cummins, K., Diendorfer, G., and Dorninger, M.: Cloud-to-ground lightning in Austria: A 10-year study using data from a lightning location system, J. Geophys. Res., 110, D09101, doi:10.1029/2004JD005332, 2005.

Schumann, U., Konopka, P., Baumann, R., Busen, R., Gerz, T., Schlager, H., Schulte P., and Volkert, H.: Estimate of diffusion parameters of aircraft exhaust plumes near the tropopause from nitric oxide and turbulence measurements, J. Geophys. Res., 100, 14 147-14 162, 1995.

Schumann, U., Huntrieser, H., Schlager, H., Bugliaro, L., Gatzen, C., and Hoeller, H.: Nitrogen Oxides from thunderstorms- Results from experiments over Europe and the Continental Tropics, paper presented at Deutsch-ÖsterreichischSchweizerische Meteorologen-Tagung (DACH), Deutsche Meteorologische Gesellschaft, Karlsruhe, Germany, 7-10 September, 2004.

Schumann, U. and Huntrieser, H.: The global lightning-induced nitrogen oxides source rate, Atmos. Chem. Phys., 7, 3823-3907, 2007 , http://www.atmos-chem-phys.net/7/3823/2007/.

Skamarock, W. C., Dye, J. E., Defer, E., Barth, M. C., Stith, J. L., Ridley, B. A., and Baumann, K.: Observationaland modelling-based budget of lightning-produced $\mathrm{NO}_{\mathrm{x}}$ in a continental thunderstorm, J. Geophys. Res., 108, 4305, doi:10.1029/2002JD002163, 2003.

Stefanutti, L., MacKenzie, A. R., Santacesaria, V., et al.: The APETHESEO Tropical Campaign: An overview, J. Atmos. Chem., 48, 1-33, 2004.

Steiger, S. M., Orville, R. E., and Carey, L. D.: Total lightning signatures of thunderstorm intensity over North Texas. Part I: Supercells, Mon. Weather Rev., 135, doi:10.1175/MWR3472.1, 2007a.

Steiger, S. M., Orville, R. E., and Carey, L. D.: Total lightning signatures of thunderstorm intensity over North Texas. Part II: Mesoscale Convective Systems, Mon. Weather Rev., 135, doi:10.1175/MWR3483.1, 2007b.

Stohl, A., Forster, C., Eckhardt, S., Huntrieser, H., Heland, J., Schlager, H., Aufmhoff, H., Arnold, F., and Cooper, O.: A backward modelling study of intercontinental pollution transport using aircraft measurements, J. Geophys. Res., 108, 4370, doi:10.1029/2002JD002862, 2003a.
Stohl, A., Huntrieser, H., Richter, A., Beirle, S., Cooper, O., Eckhardt, S., Forster, C., James, P., Spichtinger, N., Wenig, M., Wagner, T., Burrows, J., and Platt, U.: Rapid intercontinental air pollution transport associated with a meteorological bomb, Atmos. Chem. Phys., 3, 969-985, 2003 b.

Stolzenburg, M., Marshall, T. C., Rust, W. D., et al.: Horizontal distribution of electrical and meteorological conditions across the stratiform region of a mesoscale convective system, Mon. Weather Rev., 122, 1777-1797, 1994.

Théry, C.: Evaluation of LPATS data using VHF interferometric observations of lightning flashes during the Eulinox experiment, Atmos. Res., 56, 397-409, 2001.

Thomas, R. J., Krehbiel, P. R., Rison, W., Hamlin, T., Boccippio, D. J., Goodman, S. J., and Christian, H. J.: Comparison of ground-based 3-dimensional lightning mapping observations with satellite-based LIS observations in Oklahoma, Geophys. Res. Lett., 27, 1703-1706, 2000.

Thompson, A. M., Tao, W.-K., Pickering, K. E., Scala, J. R., and Simpson, J.: Tropical deep convection and ozone formation, Bull. Am. Meteorol. Soc., 78, 1043-1054, 1997.

Uman, M. A., McLain, D. K., and Krider, E. P.: The electromagnetic radiation from a finite antenna, Am. J. Phys., 43, 33-38, 1975.

Wacker, R. S. and Orville, R. E.: Changes in measured lightning flash count and return stroke peak current after the 1994 U.S. National Lightning Detection Network upgrade: 1. Observation, J. Geophys. Res., 104, 2151-2157, 1999.

Wang, Y., DeSilva, A. W., and Goldenbaum, G. C.: Nitric oxide production by simulated lightning: Dependence on current, energy, and pressure, J. Geophys. Res., 103, 19 149-19 159, 1998.

Wiens, K. C., Rutledge, S. A., and Tessendorf, S. A.: The 29 June 2000 supercell observed during STEPS. Part II: Lightning and charge structure, J. Atmos. Sci., 62, 4151-4177, 2005.

WMO: Scientific Assessment of Ozone Depletion: 1994, World Meteorological Organization Global Ozone Research and Monitoring Project, Report No. 37, 1995.

Zhang, X. J., Helsdon, J. H., and Farley, R. D.: Numerical modeling of lightning-produced $\mathrm{NO}_{\mathrm{x}}$ using an explicit lightning scheme: 1. Two-dimensional simulations as a "proof of concept", J. Geophys. Res., 108, 4579, doi:10.1029/2002JD003224, 2003. 